Portland State University

PDXScholar

Summer 8-12-2016

\title{
"On This, We Shall Build": the Struggle for Civil Rights in Portland, Oregon 1945-1953
}

Justin LeGrand Vipperman

Portland State University

Follow this and additional works at: https://pdxscholar.library.pdx.edu/open_access_etds

Part of the Civil Rights and Discrimination Commons, and the United States History Commons Let us know how access to this document benefits you.

Recommended Citation

Vipperman, Justin LeGrand, "'On This, We Shall Build": the Struggle for Civil Rights in Portland, Oregon 1945-1953" (2016). Dissertations and Theses. Paper 3124.

https://doi.org/10.15760/etd.3120

This Thesis is brought to you for free and open access. It has been accepted for inclusion in Dissertations and Theses by an authorized administrator of PDXScholar. Please contact us if we can make this document more accessible: pdxscholar@pdx.edu. 
"On This, We Shall Build":

The Struggle for Civil Rights in Portland, Oregon 1945-1953

by

Justin LeGrand Vipperman

A thesis submitted in partial fulfillment of the requirements for the degree of

Master of Arts

in

History

Thesis Committee:

Katrine Barber, Chair

David Johnson

Tim Garrison

Roberta Hunte

Paul Sivitz

Portland State Univesity

2016 
(C) 2016 Justin LeGrand Vipperman 


\begin{abstract}
Generally, Oregon historians begin Portland Civil Rights history with the development of Vanport and move quickly through the passage of the state's public accommodations law before addressing the 1960s and 70s. Although these eras are ripe with sources and contentious experiences, 1945 to 1953 provide a complex struggle for civil rights in Portland, Oregon. This time period demonstrates the rise of local leaders, wartime racial tensions, and organizational efforts used to combat inequality. 1945 marked a watershed moment in Portland Civil Rights history exhibiting intergroup collaboration and interracial cooperation converging to eventually provide needed legislation. Although discrimination continued after 1953, the era between 1945 and 1953 provided an era of change upon which subsequent movements in Portland were based. My thesis uses material from various collections to piece together the early struggle for civil rights in Portland, and more broadly, Oregon. These documents show that the local struggle started before the classical phase of the Civil Rights Movement, usually defined as Brown v. Board of Education to the Civil Rights Act of 1964. By focusing on the classical phase of civil rights, historians miss the building of a strong foundation for Portland's Civil Rights history. My research proves the existing nuances of the fight for equality by looking at local movements rather than the national struggle. This study demonstrates the nuances by focusing on rising racial tension, the efforts to document them, and the strategies used to combat discrimination.
\end{abstract}




\section{Acknowledgments}

I would like to express my sincere gratitude to my thesis committee chair, Dr. Katrine Barber who has greatly influenced my academic experience. She has pushed me in order to achieve success and I am deeply grateful. Dr. Barber is an advisor, counselor, task master, therapist, and sounding board, without her this project would not have been possible. She first suggested I intern with the City Club of Portland which led to my interest in Portland's Civil Rights Movement. She has continued to encourage me with her unending enthusiasm for western history and I am indebted to her. Thank you Dr. Barber.

I would like to thank my committee members, Dr. David Johnson, Dr. Roberta Hunte, Dr. Paul Sivitz, and Dr. Tim Garrison for their support and encouragement. Dr. Johnson provided the needed encouragement to carry on when I thought I could not finish. Dr. Sivitz continually checked in always believing my abilities were better than I believed. Dr. Garrison pushed me to finish and provided the necessary fuel to continue. I am grateful for Dr. Hunte and her support of my work. She provided a different perspective and helped me to understand the importance of including it in my finished work.

I would be remiss if I did not also thank Dr. Ethan Johnson, Dr. Darrell Millner, and Dr. Patricia Schechter. Without their help this work would not have been possible. Dr. Johnson pushed me in his course to see a broader perspective which made me uncomfortable but allowed for a deeper understanding of the struggle for civil rights. Dr. Millner took time out to provide alternative avenues in which to direct my thesis. Dr. 
Schechter provided a year of support while Dr. Barber was on sabbatical, administering my minor field exam, providing support for my thesis, and pushing me to look at the Black experience on a national level. Without her this work would still be in my head. I extend my deepest thanks to the local archives I used over the past three years. Portland State University Special Collections and Cristine Paschild have been amazing. I appreciate their help in securing many of the documents. I am grateful to the University of Oregon Special Collections as I spent many hours combing through NAACP files for the "smoking gun." Oregon State University provided Urban League information online which made it more accessible, however. Lastly, this project would not have been possible without the support of the City Club of Portland along with Greg Wallinger, Roger Eiss, and Chris Trejbal. My sincere thanks to the organization for their assistance.

My extended family and friends have provided much encouragement and I could not have accomplished this work without them. Many thanks to my mother Maudie Vipperman who supported me in going back to school and working on a graduate degree, she made it easy with a lot of late night phone calls. Huge thanks to my in-laws Mitch and Karen Bunn, they have been instrumental in my success and I am eternally grateful for their various forms of assistance and encouragement. A special thanks to Chris and Alex Cooper for always asking for an update and listening to my rants about African American Oregon history. They have helped me focus my argument while continuing their friendship. A hearty thanks to David P. Hedberg and Taylor Rose for their friendship, advice, and editing skills, without them I may not have made it through the process. And finally, thanks to David Greene for his support on a weekly basis. Every 
week he asked if I was finished with my thesis. Although annoying at times, this question always made me think about what I could be working on that week.

Finally, I owe my deepest gratitude to my wife Rebecca Vipperman who supported and encouraged me through this process. Becky worked tirelessly to support me financially, as well as emotionally while I pursued my education. She took care of our children for the majority of the time. She is an amazing wife and mother, she is my best friend, and I could not have done this without her. Thank you Becky for all of your love, encouragement, and support. 
Tables of Contents

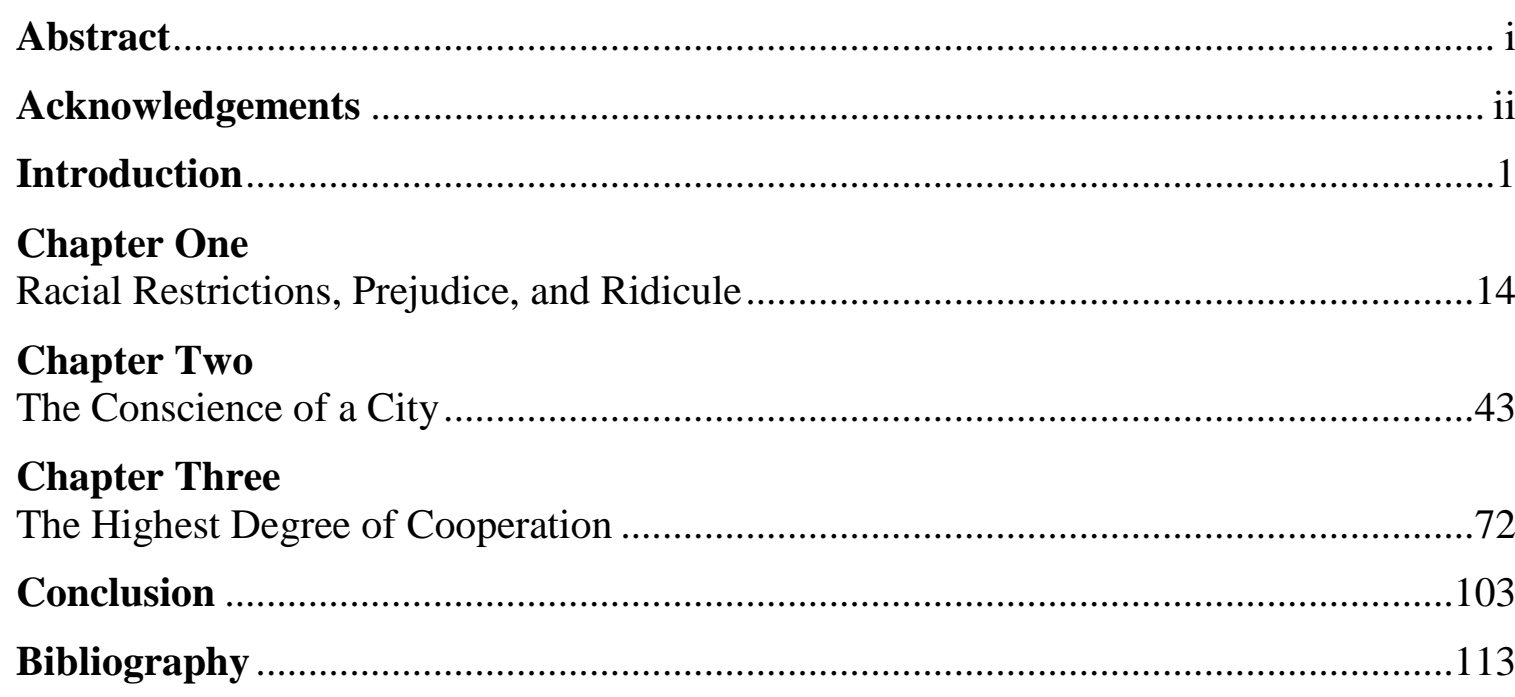




\section{Introduction}

In the summer of 2015, Oregon Public Broadcasting aired an insightful documentary titled Portland Civil Rights: Lift Ev'ry Voice. The documentary presented the history of the Civil Rights Movement in Portland, Oregon, focusing on the pivotal 1960s and 1970s. ${ }^{1}$ The film highlighted that era because of the increased Black participation, militant organizations, and growing discrimination of the periods. However, increased discrimination, newly founded organizations, and expanded interracial activism took place in the two decades leading up to the 1960s. The documentary focused its 1940's information on the low hanging fruit of the 1948 Vanport flood as a watershed moment in the local struggle. But without the foundation of the 1940s and early 50s from which later years scaffolded, Portland's civil rights history seemingly appeared out of nowhere. The footing established during this earlier period is important because it reveals interracial cooperation in the struggle for civil rights made necessary by a smaller population of African Americans relative to other West Coast cities. My research places the year 1945, not 1948, as a pivotal year for the local struggle with racial tensions reaching a high point, a moment of increased White participation in the struggle, and the founding of a branch of the Urban League in Portland. Furthermore, it brings to light the intergroup collaboration necessary to pass Oregon's statewide Accommodations Act in 1953.

\footnotetext{
${ }^{1}$ Nadine Jelsing, Portland Civil Rights: Lift Ev'ry Voice, Oregon Public Broadcasting August 18, 2015. Accessed May 23, 2016. http://www.opb.org/television/programs/oregonexperience/segment/portland-civil-rightslift-evry-voice/.
} 
Historically, the West has been viewed as a region of freedom and liberation by Americans. However, westward migrating African Americans found that freedom only extended to White settlers and then only sometimes. While White southerners moved westward to free themselves from debt, start new lives, and gain land, African Americans encountered discrimination. ${ }^{2}$ Rather than acquiring land, Black pioneers worked menial jobs such as day laborers, cooks, domestic housekeepers, servants, or unskilled laborers. ${ }^{3}$ However, the frontier experience was also an African American experience as economic exchange promoted cross-cultural interactions between multiple races in the West. ${ }^{4}$ Through the nineteenth and twentieth centuries minority communities learned to live within the systemic racism and prejudice of the West.

Portland exhibited a history of racial injustice and discrimination that extended back to the territory's founding. Exclusion laws beginning in 1844 drove African Americans to settle outside Oregon. This limited the Black population. ${ }^{5}$ African Americans who chose to stay in the territory were required to be whipped every 6 months until they left, according to the 1844 exclusion law. Oregon's provisional government

\footnotetext{
${ }^{2}$ Gregory Nokes, Breaking Chains: Slavery on Trial in the Oregon Territory (Corvallis: Oregon State Press, 2013), 11-20.

${ }^{3}$ Quintard Taylor. In Search of the Racial Frontier: African Americans in the American West 1528-1990 (New York: W.W. Norton \& Company, 1998), 97.

${ }^{4}$ Margaret Washington, “African American History and the Frontier Thesis,” Journal of the Early Republic 2 (1993), 230-241.

${ }^{5}$ Elizabeth McLagan. A Peculiar Paradise: A History of Blacks in Oregon, 1788-1940 (Portland: The Georgian Press, 1980), 173.
} 
included an exclusion clause that was incorporated into the state's constitution in 1857 and was not removed until $1927 .{ }^{6}$

World War II radically shaped racial dynamics through increased Black migration to the West. The western Black population grew by 33 percent as a result of the war. Expanding job opportunities and African American military personnel ending their service in the West and choosing to settle permanently contributed to the growth. ${ }^{7}$ This shift produced more interracial contact with Whites who were unsure of the growing population. Western cities saw enormous growth during this period, along with hostile attitudes from White citizens.

Portland's tense racial climate of the 1940's was made worse by the influx of African Americans migrating to work at local shipyards. War production centered around five major metropolitan areas, including Portland which, due to a lack of laborers, brought in workers from around the country. ${ }^{8}$ The increased population of African Americans outweighed the prewar community tenfold and the growth threatened the social norms of many Oregonians with rapid development, public housing, and a diverse population. Black migrant workers believed they would find more "liberal attitudes" in the West, but it was similar to the areas they left behind. ${ }^{9}$ Upon arrival, African

\footnotetext{
${ }^{6}$ Elizabeth McLagan, "The Black Laws of Oregon, 1844-1857," Blackpast.org 2015, accessed May 18, 2016, http://www.blackpast.org/perspectives/black-laws-oregon-18441857.

7 Taylor. In Search of the Racial Frontier, 251-252.

${ }^{8}$ Taylor, In Search of the Racial Frontier, 254. Elizabeth McLagan. A Peculiar Paradise: A History of Blacks in Oregon, 1788-1940 (Portland: The Georgian Press, 1980), 173. ${ }^{9}$ Rudy Pearson, "'A Menace to the Neighborhood': Housing and African American in Portland 1941-1945," Oregon Historical Quarterly 102 (2001): 158-179.
} 
Americans encountered signs that read "We don't serve Negroes, Jews, and Dogs" in Portland restaurants. ${ }^{10}$ Portland mayor Earl Riley said: "Portland can absorb only a minimum of Negroes without upsetting the city's regular life." ${ }^{11}$ White supremacy and racism made Portland a violent area for African Americans as they encountered hostile neighbors and police brutality.

In terms of the Black population, a rapid increase and a subsequent decrease was the major difference between Portland and other West Coast Cities. The African American population in Portland increased from 1,931 in 1940 to 22,000 in 1944. After the war the population decreased to 9,529 , the lowest black population in the five western metropolitan areas. The African American community relied on interracial participation in local civil rights because the black population made up such a small portion of Portland. Interracial activism was not unique to Portland during the classical phase of the civil rights movement as white activists took part in freedom rides, bus boycotts, and sitins nationally. However, the reliance on interracial cooperation at such an early stage is unique to areas with small minority communities. ${ }^{12}$

Historians, much like the OPB producer Nadine Jelsing, generally focus on Vanport when detailing the Portland Civil Rights Movement. Located eight miles north of Portland's city center and built by Henry Kaiser of California, Vanport provided

\footnotetext{
${ }^{10}$ Jon Tuttle, Local Color: Oregon's Forgotten History Civil Rights, Oregon Public Broadcasting May 01, 1999, accessed May 23, 2016, 1:48 http://watch.opb.org/video/1593884540/. ${ }^{11}$ Quoted in Elizabeth McLagan. A Peculiar Paradise: A History of Blacks in Oregon, 1788-1940 (Portland: The Georgian Press, 1980), 173.

${ }^{12}$ Dwayne Mack, Black Spokane: The Civil Rights Struggle in the Inland Norwest (Norman: University of Oklahoma Press, 2014).
} 
housing for Oregon Shipbuilding Company workers. ${ }^{13}$ Vanport, like Portland, was segregated by neighborhoods, leading to racial tensions. By 1948, 6,000 African Americans lived in Vanport, which housed a total of 18,500 residents. ${ }^{14}$ On Memorial Day 1948, a dike along the Columbia River ruptured, flooding the city and sending residents to higher ground and new homes. Due to redlining, Black residents were forced into an already crowded Albina neighborhood north of the Willamette River.

The importance of the Vanport experience represents an increased Black population that housing authorities refused to help, labor unions disputed segregation, and displaced residents forced into an existing racially segregated neighborhood bursting at the seams. However, the problem with starting the history of civil rights in Portland from the Vanport flood is a seeming lack of struggle leading up to 1948. Previous civil rights scholarship in Portland has focused on the readily available sources and the Vanport community and 1948 flood provided documentation, oral histories, and compelling photographs. However, the years leading up to the flood were marked by discrimination, increased racial tension, and organizing, which is why May 30, 1948, became so explosive.

Although recent scholarship has started highlighting local historical events, traditionally historians have focused on the southern Civil Rights movement. Contemporary historians define the classical phase of civil rights history as a southern struggle beginning with the Brown vs The Board of Education decision and ending with

${ }^{13}$ Carl Abbott, Portland in Three Centuries: The Place and the People (Corvallis: Oregon State University Press, 2011), 119-125.

${ }^{14}$ Abbott, Portland in Three Centuries, 124. 
the Voting Rights Act of $1964 .{ }^{15}$ In 2005, Jacquelyn Dowd Hall argued for a geographical extension of the Civil Rights era: "confining the civil rights struggle to the South... simultaneously elevates and diminishes the movement." ${ }^{\prime 16}$ Likewise, historian J. Todd Moye explains the importance of the long civil rights movement which extends beyond Brown and Rosa Parks. ${ }^{17}$ Moye suggests an extended timeframe allows for greater emphasis on church and club leaders who struggled to start the movement.

The years 1930 to 1957 provided momentum for the classical phase of the movement and inspired change in larger communities around the United States. Without understanding this era, civil rights history escalates seemingly quickly. However, when looking at the long civil rights movement, a more encompassing and broader period in which a much longer struggle with local activists shape national events can be defined. Although Civil Rights historians reinforce the classical phase of the movement as being most significant, local studies provide nuance. In the case of Portland, the movement leading up to the passage of the Accommodations Act in 1953 has not been fleshed out. Portland's Civil Rights history provides the possibility of extending a study beyond the 1950s, where most scholars begin. It also includes instances of cross-cultural interaction

${ }^{15}$ Emilye Crosby, Civil Rights History From the Ground Up: Local Struggles, A National Movement (Athens: The University of Georgia Press, 2011), 9.

${ }^{16}$ Jacquelyn Dowd Hall, "The Long Civil Rights Movement and the Political Uses of the Past," Journal of American History 91 (March 2005): 1234.

${ }^{17}$ J. Todd Moye, "Focusing Our Eyes on the Prize: How Community Studies Are Reframing and Rewriting the History of the Civil Rights Movement," in Emilye Crosby, Civil Rights History From the Ground Up: Local Struggles, A National Movement (Athens: The University of Georgia Press, 2011), 163. 
not seen in the classical phase of the movement, therefore, demonstrating broader participation within the Portland Civil Rights Movement.

Western historians have struggled to present minority voices within twentieth century scholarship. Prior to the 1980s, historians such as Walter Prescott Webb and Earl Pomeroy focused on the white experience of the frontier and western history. ${ }^{18}$ Beginning in the late 1980s, Patricia Nelson Limerick, Richard White, William Cronon, and Donald Worster presented what eventually became known as "new western history," which provided accounts of minorities, women, and the poor working classes. ${ }^{19}$ These accounts highlighted the different experiences of these groups compared with the heavily researched white one. New Western History gave rise to scholars like Quintard Taylor and journalist Isabel Wilkerson who have published works on the African American experience, specifically leading to an increased awareness of Black issues in the West. ${ }^{20}$

\footnotetext{
${ }^{18}$ Walter Prescott Webb, The Great Plains (New York: Grosset and Dunlap, 1931). Earl Pomeroy, "Toward a Reorientation of Western History: Continuity and Environment," The Mississippi Valley Historical Review, 579-600. Earl Pomeroy, In Search of the Golden West: The Tourist in Western American (New York: Knopf Doubleday Publishing, 1957). Earl Pomeroy, "The Changing West," in John Higham, ed. The Reconstruction of American History (Charleston: Nabu Press, 2011). Earl Pomeroy, The Pacific Slope: A History of California, Oregon, Washington, Idaho, Utah, and Nevada (Reno: University of Nevada Press, 2003).

${ }^{19}$ Patricia Nelson Limerick, The Legacy of Conquest: The Unbroken Past of the American West (New York: W.W. Norton \& Company, 1987). Richard White, "Race Relations in the American West," American Quarterly 1986, 396-416. Richard White, It's Your Misfortune and None of My Ow: A New History of the American West (Norman: University of Oklahoma Press, 1991). William Cronon, Nature's Metropolis: Chicago and the Great West (New York: W.W. Norton \& Company, 1992). Donald Worster, Rivers of Empire: Water, Aridity, and the Growth of the American West (Oxford: Oxford University Press, 1985).

${ }^{20}$ Quintard Taylor, "Facing the Urban Frontier: African American History in the Reshaping of the Twentieth-Century American West," The Western Historical Quarterly, 2012, 4-27. Quintard Taylor, In Search of the Racial Frontier: African Americans in the
} 
These scholars have made it possible for a new class of historians to look at micro level struggles of race and civil rights. Historian Rudy Pearson focused his scholarship on housing and labor in Portland, Oregon, leading to a breadth of knowledge around post and pre-war African Americans. Dwayne Mack's Black Spokane studies the civil rights struggle in a small inland town in Washington. Historians Ethan Johnson and Felicia Williams look at desegregation in Portland's public school system in their 2010 article. These scholars shed light on the intricacies of race relations in Pacific Northwest cities. Moreover, the work of Patricia Schechter, Avel Gordly, and Blackpast.org provide increased opportunities for minorities voices to be heard. ${ }^{21}$ Building on their work, I intend to shed light on a period which has been over looked.

One reason the era has not been documented is due, in part, to the lack of sources. Dolores Hayden explains the importance for historians to begin with "substantial

American West (New York: W.W. Norton \& Company, 1998). Quintard Taylor, "Through the Prism of Race: The Meaning of African-American History in the West," in A New Significance: Re-Envisioning the History of the American West, by Clyde A. Milner II (New York: Oxford University Press, 1996), 289-300. Isabel Wilkerson, The Warmth of Other Suns: The Epic Story of America's Great Migration (New York: Vintage Books, 2010).

${ }^{21}$ Rudy Pearson, African-Americans in Portland, Oregon, 1940-1950. Work and Living Conditions: A Social History (Dissertation, Pullman: Washington State University, 1996). Rudy Pearson, “'A Menace to the Neighborhood': Housing and African Americans in Portland, 1941-1945," Oregon Historical Quarterly 2001, 158-179. Stacey L. Smith, Freedom's Frontier: California and the Struggle over Unfree Labor, Emancipation, and Reconstruction (Chapel Hill: The University of North Carolina Press, 2013). Mack, Black Spokane, $x x$. Ethan Johnson and Felicia Williams, "Desegregation and Multiculturalism in the Portland Public Schools," Oregon Historical Quarterly (Spring 2010), 6-37. Avel Louise Gordly and Patricia A. Schechter, Remembering the Power of Words: The Life of an Oregon Activist, Legislator, and Community Leader (Corvallis: Oregon State University Press). 
amounts" of sources in hand. However, that is not always possible. ${ }^{22}$ One difficulty is finding African American created sources before official organizational branches had been founded. Moreover, in the case of the Urban League of Portland, very little material is archived because African Americans believed the Oregon Historical Society (OHS) was a White institution and did not trust their history would be represented accurately, leading to a lack of donations from the Black community. ${ }^{23}$ Portland State University Special Collections holds a few African American collections due to the efforts of the Black Studies Department and History faculty member Patricia Schechter. However, these materials lack information before 1950 .

The second reason for a lack in scholarship from the 1930s through the 1940s is the issue of piecing archival sources together from several repositories. Not one archive holds all of the material necessary. For this reason, many scholars have skipped over the 1930s and 40s to research the low hanging fruit of the 1950s through the present. I have conducted research for this project in the Oregon Historical Society, Portland State University Special Collections, University of Oregon Special Collections and University Archives, Oregon State University Multicultural Archives, City Club of Portland Archives, and the City of Portland Archives and Records Management. Archivists and local leaders suspect there is more archival information in personal basements waiting to be uncovered and archived.

${ }^{22}$ Dolores Hayden, The Power of Place: Urban Landscapes as Public History (Cambridge: The MIT Press, 1997), 231.

${ }^{23}$ Discussion with Dr. Darrell Millner, Professor Emeritus, Black Studies Department, Portland State University, March 10, 2016. 
Although sources are limited, 1945 to 1953 is an important era of increased participation among middle-class African Americans in the emerging movement, which is seldom included as part of the classical phase. The work of the Urban League in Portland, Oregon proves the movement in the Pacific Northwest began before the Brown decision. Sources demonstrate interracial participation throughout the 1940s, suggesting the movement was part of a broader postwar liberal idealism. ${ }^{24}$ The sources provide a narrative of hard working middle-class men working to change racial dynamics in a western port city with an increasing Black population and increased White participation after World War II ended.

My study demonstrates the importance of local history by analyzing documents, reports, newspapers, and organization meeting minutes. It also brings together community sentiment through The Oregonian to provide commentary by the White community, as well as the two African American newspapers, The Observer and The Advocate, to provide African American views. These newspapers were viewed at the Portland State University Special Collections and the Oregon Historical Society. Shifts in interactions between the White and Black communities are seen within this local history and tracked in this thesis.

\footnotetext{
${ }^{24}$ I acknowledge that it is difficult to explain the complex nature of racism and discrimination. People cannot be defined simply by their race, color, ethnicity, or religion. Postwar liberalism is one way that white activists have been categorized. However, I cannot speak to the complex nature of each person or their motivation for participating in the Civil Rights Movement.
} 
The importance of studying local Civil Rights history is to understand the movement beyond the classical period described as Brown to Memphis. ${ }^{25}$ Local histories provide a stage that is often much longer than the classical phase. In this way, Civil Rights history is seen outside the confines of the 1950s and 1960s classical southern movement. The classical phase also limits the movement to the South and by doing so it leaves out local movements and influential leaders, especially in the West. Aldon D. Morris states in The Origins of the Civil Rights Movement, "Instead of one homogeneous civil rights movement, there were dozens of local movements. This fact tends to become obscured by the names of famous activists, organizations, and abstract concepts. ${ }^{26}$ Local movements demonstrate nuanced actions that make each location different than the next.

I have structured my chapters around three main themes. Chapter one highlights the factors of rising racial tensions that led to needed legislation. In this chapter I focus on racial discrimination, beginning with an attempt to stop the showing of the film The Birth of a Nation in Portland. I shed light on police brutality using several court cases. Lastly, I point to segregation and discrimination in housing and education. These factors led to increased tension between Portland's white and Black communities.

Chapter two focuses on two City Club of Portland reports which highlight interracial cooperation and intergroup collaboration in the struggle for civil rights. In 1945, the City Club of Portland published a report entitled "The Negro in Portland"

${ }^{25}$ Emilye Crosby, Civil Rights History from the Ground Up: Local Struggles, A National Movement (Athens: University of Georgia Press, 2011), 7-8.

${ }^{26}$ Aldon D. Morris, The Origins of the Civil Rights Movement: Black Communities Organizing for Change (New York: The Free Press, 1986), 40. 
detailing the African American experience. ${ }^{27}$ Information for the report came from the NAACP and the Urban League. In 1950, the City Club published another report offering solutions, including a city accommodations ordinance. The City Club reached a broad audience due to its membership and access to white leadership. In this way, the City Club became a vehicle of validity for the information that Portland's early civil rights leaders were trying to circulate. The reports are important because they offer a local view of Civil Rights history, indicating the movement started before the classical phase and providing examples of cross-cultural interactions leading to broad participation in the post-war period. The reports also highlights 1945 as a watershed moment in the local struggle. Chapter three highlights the strategies the NAACP, City Club of Portland, and Urban League used in fighting racial discrimination. This chapter examines intergroup collaboration in an attempt to provide equality for African Americans. The organizations worked together in an attempt to pass a city ordinance making it unlawful to discriminate in public businesses. However, the ordinance was struck down. The chapter shows the importance of intergroup collaboration as the three organizations worked together. Although the ordinance ultimately failed, their work set the stage for a much broader state accommodation law which passed in 1953.

Historians cannot gain a full grasp of the complex nature of civil rights history outside of the South without understanding the small stories of interracial and intergroup cooperation necessary in the fight for racial justice in the West. Although the struggle in Portland illustrates a broad theme of inequality and discrimination fought by Black

27 “The Negro in Portland," Portland City Club Bulletin July 20, 1945. 
leaders from several organizations, it also illustrates the convergence of a small African American population, White post-war liberals, and Black civic groups competing for status and viability. The struggle for civil rights in Portland is more than the 1960s, 1970s, and 1980s. It's more than White against Black, redlining, or education segregation and desegregation. The period between 1930 and 1953 sheds light on interracial connections and intergroup collaboration which become important during the classical phase of the movement in Portland. The post-war period in Portland provides the context for the turbulent 1960s and 1970s upon which most historians focus. 


\section{Chapter One}

\section{"Racial Restrictions, Prejudice, and Ridicule"}

"Many Negro people are fearful that the ending of this global war will mark the beginning of a new series of atrocities to be heaped upon them."1

On the night of August 20, 1945, Scott E. Thomas walked into the Guilds Lake home of Beatrice Terry and shot and killed her after a confrontation over another man. The getaway driver, Cliff Blivens, dropped Thomas off and drove to the end of the street where he heard the shots before turning the car around and picking up Thomas. They fled the scene, and when police arrived at 11 p.m., witnesses stated that Thomas was at the home of Ervin Jones. Sargent Dan Mitola and detective Mike O'Leary arrived at 2 a.m. and covered the front door while detective Bard Purcell went around to the rear of the house. According to Mitola, they knocked on the door and identified themselves as police officers and asked to speak with Ervin Jones. "He refused to open the door and we finally started to kick it open," Mitola explained in the police report. As the door opened Mitola and O'Leary heard three shots from the rear of the home. They ran to find Purcell "leaning through one of the rear windows, gun in hand."2 Purcell explained, "When they [Mitola and O'Leary] started to break the front door, Jones went to the bedroom and came back loading a gun. I broke the window glass and leveled my gun at him, telling him to put up his hands and drop the gun." According to Purcell, Jones fired his gun at him but it misfired. Jones then spun around as the door was kicked in and fired two shots

\footnotetext{
${ }^{1}$ William McClendon, "For Better Understanding," The Observer August 17, 1945, p. 4. 2 "2 Negroes Die, 1 in Jail in Guilds Lake Flare-up," The Oregonian, August 22, 1945, p. 9.
} 
at the officers. Purcell fired one shot in return, fatally wounding Jones. The officers were cleared after a quick investigation by the chief of police justified the shooting. ${ }^{3}$

The details of the shooting from the Jones family varied from the officer's account. An attorney for the National Association for the Advancement of Colored People (NAACP), Irvin Goodman, recounted the family's version in a letter sent to the Observer and the Oregonian. "Refused admittance, the detectives in the front broke open the door, the one in the rear a window," Goodman wrote. "At this point Jones, believing the police were robbers, although they claim they said they were officers, allegedly fired shots at the detectives in front while the detective in the rear shot Jones in the back and killed him." Goodman, angry about the exonerated detectives, stated, "The least that should be done when an admittedly innocent man is killed is that a thorough investigation be conducted by the district attorney's office." However, he said, "Purcell has been exonerated of any blame in the Negro's death."4

1945 signaled the precipice of growing racial tension in Portland, Oregon. African Americans had tolerated discrimination, segregation, vandalism, and police brutality throughout the early twentieth-century. Whites perceived the growing number of Black shipyard laborers during WWII to magnify the problems as White citizens found ways to insulate themselves. Racial tensions boiled over in 1945, with the death of Ervin Jones.

\footnotetext{
${ }^{3}$ Ibid.

${ }^{4}$ Irvin Goodman, "Demand for an Official Investigation," The Observer, August 31, 1945, p. 4. Irvin Goodman, "Police Inquiry Asked," The Oregonian, September 5, 1945, p. 8. "Negro to Face Grand Jury," The Oregonian, August 24, 1945, p. 6.
} 
However, the growing problem stemmed from years of poor treatment by Portland's White citizenship and an increasing Black population.

This chapter focuses on the growing racial tension in Portland starting with the fight to ban the film The Birth of a Nation. Although African American discrimination, as well as total exclusion, began before the founding of the Oregon Territory, my focus specifically looks at the twentieth-century because it demonstrates the creation and organization of Black-led civic groups who fought discrimination using interracial membership and intergroup cooperation. The organizations founded during this time were instrumental in the passage of a statewide accommodations bill in 1953, marking the beginning of the classical phase of the Civil Rights movement in Portland. It is important to understand the specific problems that led to growing tensions in order to understand the struggle for civil rights in Portland. Growing tensions also strengthened the foundation on which Portland's Civil Rights Movement was based. The following instances of racial discrimination, police brutality, and injustice delineate how and why interracial activists got involved in fighting for civil rights.

\section{"Justifiable Homicide"}

"I am not of the opinion that a killing is ever justified merely because the superior officer of a police department exonerates his subordinate in a case of this type."

The Portland Council of Churches and the NAACP cooperated in building a case

against the police officer after the shooting death of Ervin Jones in September 1945. " $\mathrm{It}$

5 "Killing of Negro to be Aired; Wife Will Return to Testify on Police Brutality," The Observer September 20, 1945, p. 1.

6 "City to Probe Negro's Death," The Oregonian, September 8, 1945, p. 7. 
is gratifying that the Portland Council of Churches is co-operating with other organizations to bring forth the facts about the Ervin Jones case at the forthcoming public inquest," the Oregonian reported. ${ }^{7}$ The organizations raised money to bring Ervin's wife, Elva Jones, back from Louisiana where she had moved after the death of her husband. ${ }^{8}$ Reverend George W. Brown urged Portland church members to contribute in order to help Elva return to testify. ${ }^{9}$

In October a coroner's inquest was scheduled into the shooting death of Ervin Jones. On October 9, 1945, the inquest began with six White jurors and Attorney Goodman representing the Jones family. Goodman believed the jurors held racial prejudices which would be in their ruling. He wanted to question the jury before he began, but the judge denied the motion. He argued the shooting took place in a Black neighborhood involving an African American family and, therefore, Black jurors should have been included on the panel. ${ }^{10}$ However, the judge refused Goodman's motion and the inquest began with the six white jurors instead of a jury of Jones' peers.

Elva Jones provided testimony that contradicted the officer's accounts. Elva testified that she and her husband lived in the home with their two children and her two sisters and their husbands. At the time of the shooting, the two husbands were working

\footnotetext{
${ }^{7}$ Horace Thurber, "Practical Religion," The Oregonian, October 1, 1945, p. 6.

${ }^{8}$ William H. McClendon, "Oregon's JUSTIFIABLE HOMICIDE," The Observer, September 20,1945, p. 4. Elva Jones moved her family back to Louisiana after the shooting death to be close to family. Erving and Elva had grown up there and had moved to Portland to work in the Kaiser shipyards.

9 "Pastors Asked to Aid Negro," The Oregonian, September 2, 1945, p. 10.

10 "Inquest Jury Hears How Negro Died in Police Raid," The Oregonian, October 10, 1945 , p. 1.
} 
the night shift at the Kaiser shipyard. Mrs. Jones testified she was awakened when she heard her husband shout "who knocks" and then heard the glass in the back window break. Her husband raised his arms in response and was shot without firing. While officers searched the home, Ervin lay dying on the bed. He told his wife he was unaware the plain clothed officers were detectives. ${ }^{11}$

Other witnesses provided similar testimony. Elva's sister, Susi Rambo, testified she did not hear anything until Jones came to her bedroom and said, "Wake up, robbers are breaking in," at which point she ran to the other room and hid with her sisters behind the bed. Later, officers entered and saw Jones dying on the floor and yelled, "Lay that gun down or I'll blow your brains out." ${ }^{\prime 2}$ The next door neighbor, Jesse B. Johnson, testified he awoke at 2 a.m. to knocking and then checked to see who it was. Someone told him to "close the door and stay inside," before hearing a man yell, "Unless someone opens the door I'll shoot through it," Then he heard the sound of two gun shots came from the other side of the wall. Johnson also testified he would have told Jones the men were officers if they had identified themselves. ${ }^{13}$

The officer's testimony described a defiant Jones, whom they believed was harboring a murder suspect. Sergeant Mitola testified that they proceeded to the Jones's home after receiving information that the suspect was there. They knocked on the door and identified themselves as police officers saying, "We want to talk to you." Mitola explained that due to the nature of the crime they were within their legal rights to "go in

\footnotetext{
11 Ibid.

12 Ibid.

${ }^{13}$ Ibid.
} 
after him." He testified that they knocked several times, clearly identifying themselves before kicking the door open but before hearing glass break on the other side of the house. He and his partner ran to find Jones dying on the bedroom floor which was different from Officer Purcell's testimony of that night. Mitola swore he did not hear anyone say, "Stick 'em up or I'll blow your damned brains out," nor did he see Purcell shoot Jones. Goodman asked about their training with Black communities and Mitola explained officers did not receive special training in dealing with African Americans. ${ }^{14}$

Purcell's testimony during the inquest differed slightly from what he told Mitola and O'Leary on the night of the shooting. Purcell testified he was looking through a small tear in the curtains where he saw Jones loading a gun and holding the door closed so the officers could not get in. This detail, framing Jones as the aggressor, was left out of Purcell's account on the night of the shooting. He also explained in his testimony that he did not break the glass in order to fire at Jones, rather, the glass was already broken and he merely pointed his gun through an already broken window. ${ }^{15}$ Purcell's account of the shooting on the night of the event was that he broke the window when Jones shot through the door. Regardless of the inconsistencies in the officer's testimonies, the jury found the shooting justified. On October 11, the Oregonian reported, "Police Raid Slaying

\footnotetext{
14 Ibid.

15 "Officer Says Shot Fired to Save Partners on Raid," The Oregonian, September 11, 1945 , p. 2.
} 
Justified, Jury Says," reporting that the jury found Purcell justified "in performance of duties and in protection of himself and fellow officers."16

The jury's decision angered Black community leaders. The NAACP quickly developed a statement suggesting the inquest was unfair and biased against the Jones family. The committee claimed the exclusion of African American jury members, the lack of a public examination by the coroner, and the refusal by the police sergeant to provide an official report demonstrated the ruling was unfair. "We are not of the opinion that the public has had full opportunity to determine whether the killing of an innocent victim was justifiable," read the statement. ${ }^{17}$ Observer editor William H. McClendon criticized the inquest for not reporting the facts, arguing the detectives did not reveal themselves to Jones as Portland Police Officers when they forced themselves into his home. He insisted the officers did not have a warrant for Jones's arrest, and were also not carrying one for Thomas, who did not look like Jones in the slightest. When they found Thomas, he denied ever knowing Jones and immediately admitted guilt. McClendon took exception with Purcell's testimony stating, "Jones never fired into the front door as charged - he fired one shot above the door near the ceiling." He also questioned Purcell's judgment stating, “The taking of Jones' life was ruthless in the most elementary sense. The detective who fired the death dealing bullet had to shoot directly across a bed where

\footnotetext{
16 "Police Raid Slaying Justified, Jury Says: Detective Killed Negro Householder While on Hunt for Murder Suspect," The Oregonian, October 11, 1945, p. 1. "Police Obtain Statement Thomas in Jones House," The Oregonian, October 14, 1945, p. 18. 17 "Officer Says Shot Fired to Save Partners on Raid," The Oregonian, 2.
} 
two babies were lying, frightened and screaming. The lives of these children, being endangered, did not even deter this officer from his murderous impulse."18

The NAACP led other Portland groups in requesting that Governor Earl Snell begin a grand jury investigation into the shooting death of Jones. ${ }^{19}$ The NAACP called the coroner's inquest "“an invitation to lawlessness, a serious threat to the security of all persons in their own homes and a grave miscarriage of justice." ${ }^{20}$ Believing the jury had been influenced by Captain Fleming's false testimony that Scott Thomas actually hid in the Jones's home, the NAACP and the Citizens Committee urged the district attorney to send the case to a grand jury. ${ }^{21}$ The NAACP demanded Fleming present his signed statement as well as other information he supposedly had: "We feel that Capt. Fleming should welcome the grand jury investigation for giving him the opportunity to present all information he possesses, including the official report of the killing made by his sergeant, which the sergeant withheld from the inquest."22 Concerned that the officer's testimony was misleading, District Attorney Thomas B. Handley announced the case would be heard by a grand jury immediately. ${ }^{23}$

\footnotetext{
${ }^{18}$ McClendon, “Oregon's JUSTIFIABLE HOMICIDE," The Observer, 4. 19 "Police Obtain Statement," The Oregonian, 18. "Probe Backed by Churches," The Oregonian, September 13, 1945, p. 9. Goodman, "Demand for an Official Investigation," The Observer, 4. Goodman, "Police Inquiry Asked," The Oregonian, 8.

20 "Police Obtain Statement," The Oregonian, 18.

21 "Group Raps Slaying Stand: Committee Hits Fleming Statement," The Oregonian, October 16, 1945, p. 9.

${ }^{22}$ Ibid.

23 Ibid.
} 
“Jury Upholds Jones Action," the Oregonian reported on October 19. ${ }^{24}$ Circuit Judge Martin W. Hawkins received the grand jury report that detailed the findings of twenty witnesses. The jury found the officers in compliance with the law as well as acting in accordance with their duties and responsibilities as police. ${ }^{25}$ Letters to the editor published by the Oregonian demonstrated that the verdict was controversial. The NAACP and Urban League suggested city officials adhere to police training recommendations set forth by the City Club detailed in their recently published "Negro in Portland" report. ${ }^{26}$ Maude B. Leas, secretary of the YWCA, believed law enforcement could eliminate tensions if the police were trained in racial tolerance. However, they continued without that training. ${ }^{27}$

A friend of Bard Purcell, Gordon M. Connelly, supported the detective. He wrote, "In all my associations with Purcell I've known him to be the kind of man who judged other men not by the color of their skin...but by the worth of their character." Connelly suggested because he was a friend of Purcell, and due to his position on the Committee of Racial Equality in Denver, Colorado, he was qualified to provide support and a glowing reference for Purcell. Connelly offered one example as to why Purcell was not a racist or a bigot. He explained how Purcell "went further than many tolerant whites" by taking an African American boxer, Andy Bundy, as his friend. "Bigots don't do that," he said. ${ }^{28} \mathrm{~A}$ letter read at the city council meeting on November 11 expressed disgust that the city

\footnotetext{
24 “Jury Upholds Jones Action," The Oregonian, October 19, 1945, p. 1.

${ }^{25}$ Ibid.

26 "Groups Ask Tolerance," The Oregonian, October 20, 1945, p. 9.

${ }^{27}$ Maude B. Leas, "YWCA on Racial Relations," The Oregonian, October 27, 1945, p. 8. ${ }^{28}$ Gordon M. Connelly, "Witness for Purcell," The Oregonian, October 31, 1945, p. 12.
} 
used public funds to pay Purcell's legal fees but refused to pay any fees accrued by Mrs. Jones. ${ }^{29}$ City officials paid Purcell's defense fees while making it difficult for Mrs. Jones to return from Louisiana in order to testify in the inquest and grand jury.

The shooting of Ervin Jones and the subsequent inquest of excessive force were the precipice of growing racial tensions in 1945. The death of Jones was the proverbial last straw as Portland African Americans had fought police brutality, segregation, and discrimination for many years. Although the death marked a turning point for civil rights activists, Portland's history of discrimination contributed to the foundation of activism seen in later years. That activism was made visible with the creation of the Portland NAACP.

\section{"Greatly Pleased by the 'Far West"”}

"We must, as a people, come here and settle down and see to it that Racehatred and color prejudice advance no further. "30

The National Association for the Advancement of Colored People created West Coast branches soon after its creation in New York. ${ }^{31}$ In 1909, a small interracial group of intellectuals organized under the goal of uniting African Americans across the country in a struggle for their rights. ${ }^{32}$ Organizing leaders believed uniting Black Americans from coast to coast would bring rapid change by raising one united voice against

\footnotetext{
29 "Legal Aid Rapped," The Oregonian, November 11, 1945, p. 15.

30 "Noted Churchman and Social Worker Visit Here," The Advocate, September 18, 1926, p. 1.

${ }^{31}$ Quintard Taylor, In Search of the Racial Frontier, 196.

${ }^{32}$ Morris, The Origins of the Civil Rights Movement, 13.
} 
discrimination. The NAACP increased in membership from 1910 through the 1920s, boasting a membership of 90,000 members and 300 local branches by $1930 .{ }^{33}$ The organization focused on economic justice throughout the depression of the 1930s, and continued to advocate against anti-lynching laws and segregation throughout the 40s and 50s. The NAACP provided legal representation for underserved African American communities, making it one of the most important equal rights advocacy organizations.

The organization moved west in 1912 to become one of the most important racial entities in the region for Black unity. ${ }^{34}$ The NAACP created A local branch in Portland two years later in 1914, joining other West Coast branches such as those in San Francisco and Seattle. ${ }^{35}$ In an effort to organize and strengthen local branches, national leaders toured the West Coast. The local membership welcomed Reverend J. Milton Waldron and his wife Martha, founding members of the national NAACP, to Portland in 1926. In an interview with Portland's African American newspaper, The Advocate, Waldron explained how Japanese and Chinese immigration laws provided a way for Black Americans to gain acceptance by demonstrating their ingenuity and work ethic without fighting other racial minorities. ${ }^{36}$ William Pickens, field secretary for the NAACP, visited in 1926, and again in 1928, and addressed the City Club of Portland on how the race

\footnotetext{
33 "NAACP: 100 Years of History," NAACP.org, (2016) accessed July 5, 2016, http://www.naacp.org/pages/naacp-history.

34 Taylor, In Search of the Racial Frontier, 237.

${ }^{35}$ Mangun, A Force for Change, 41. Taylor, In Search of the Racial Frontier, 196.

36 Ibid.
} 
problem could be solved. ${ }^{37}$ The City Club boasted one of the largest memberships in the city and provided a broad audience for the national secretary.

In 1916, West Coast branches of the NAACP began a unified fight against discrimination by attempting to ban the film, The Birth of a Nation. The film was the nation's first full length film. Based on the play The Klansmen by Thomas Dixon Jr., Birth of a Nation portrayed the South in the aftermath of the Civil War and the abolition of slavery. It followed two southern families through the Civil War and into Reconstruction. The film depicted Civil War veteran Ben Cameron forming the Ku Klux Klan in an attempt to restore law and order in the old republic and portrayed Reconstruction as a humiliating to Whites who were "forced to acknowledge Blacks as equals." ${ }^{38}$ Concerned African Americans saw the film as a celebration of the KKK and worried what it meant for their communities. They were also angry at the portrayal of African Americans as incompetent, lustful savages. Local western NAACP branches protested independently in cities such as Seattle, Denver, and Dallas. However, California branches were the first to strike a marginal victory in removing a few racially derogatory scenes. ${ }^{39}$

An initial attempt to ban the film in Portland was unsuccessful as the NAACP tried cooperating with local interracial leaders. National NAACP Secretary Mary Childs Nerney urged local branches to take action in banning the film in their city. Nerney advised the editor of The Advocate, Beatrice Morrow Cannady, to reach out to Black and

\footnotetext{
37 Ibid.

${ }^{38}$ Ibid., 121.

${ }^{39}$ Taylor, In Search of the Racial Frontier, 238.
} 
White clergy, civic organizations, and women's clubs to protest the film. ${ }^{40}$ Cannady wrote a letter to the Oregonian on July 4, 1915, denouncing the showing due to race hatred and historical inaccuracies stating, "The picture offers a false and erroneous excuse for discrimination and segregation." ${ }^{41}$ However, the film debuted on August 29, 1915, despite public outcry from Portland's African American community and a few White residents. ${ }^{42}$ A film review in the Oregonian stated, "It tells the story of the great conflict between the North and the South, tells it fearlessly and without any attempt at stirring up prejudices...Their interpretations are flawless. ${ }^{43}$ Enthralled Portlanders attended the four week run in large audiences to view the new picture depicting the birth of the KKK. ${ }^{44}$ Although other events contributed to racial tension prior to the film, The Birth of a Nation launched a growing strain between Portland's Black and White communities.

In 1931, 16 years later, local NAACP leaders successfully stopped the release of the film in Portland with interracial cooperation. In December, the Board of Motion Picture Censors approved a Christmas Day debut followed by a week of shows. NAACP

${ }^{40}$ Mangun, A Force for Change, 123.

${ }^{41}$ Beatrice Morrow Cannady, "Film is Protested: Negroes Oppose Showing of 'The Birth of a Nation' Appeal Made to Churches," The Oregonian July 4, 1915, section 1, p. 3.

${ }^{42}$ Mangun, A Force for Change, 126.

${ }^{43}$ Edith Knight Holmes, "'The Birth of a Nation' is Superb: Pictorial History of Civil War at Heilig is Triumph in Film Production," The Oregonian August 9, 1915, section 4, p. 3

44 "'Birth of a Nation' Thrills: Heilig Audience Awed by Historical War-Time PhotoDrama," The Oregonian September 5, 1915 section 4, p. 2.; "Society: A Number of Society Matrons," The Oregonian September 6, 1915 p. 12.; "Carriers to see Film: 200 of the Oregonian Guests at 'Birth of a Nation' Tonight," The Oregonian September 10, 1915, p. 17. 
president Clarence Ivey and Beatrice Cannady immediately convened with White supporters to stop the film from being shown. Censors banned the picture earlier in the year. However, Triangle Film Company vice president Hunter Glover affirmed the company had edited all offensive content, "thereby eliminating many features considered by some as questionable. ${ }^{45}$ Cannady was suspicious and led the NAACP with President Ivey, Portland physician DeNorval Unthank, Reed College President Norman F. Coleman, attorney John Jamison, Alice Handsaker, and Bahá'í leader George Orr Latimer in a private viewing of the edited version. ${ }^{46}$ Cannady argued in an Advocate editorial, "that no material deletions had been made and that the picture was just as objectionable. ${ }^{\circ 7}$ The next morning Portland's mayor convened a special hearing resulting in the withdrawal of the film, prompting Cannady to write, "'Birth of a Nation' was denied exhibition in the 'City of Roses' [through] the beautiful spirit of cooperation. ${ }^{\prime 48}$ The local branch of the NAACP implored White residents, as well as local leaders and civic clubs, to stand united in their efforts to ban the film. However, White animosity continued contributing to growing racial stress.

The National Association for the Advancement of Colored People began fighting a war on fair employment practices nationwide in 1946. Locally, many African American men and women lost employment at shipyards as production decreased at the end of

${ }^{45}$ Carrie L. Ingersoll to Robert W. Bagnall, March 4, 1931, NAACP PB in Kimberley Mangun, A Force for Change: Beatrice Morrow Cannady and the Struggle for Civil Rights in Oregon, 1912-1936 (Corvallis: Oregon State University Press, 2010), 133. ${ }^{46}$ Ibid., 135.

${ }^{47}$ Beatrice Morrow Cannady, "'Birth of a Nation' Barred From Portland: Many Groups Protest Exhibit," The Advocate, January 2, 1932, p. 1.

48 "That Film Again," The Advocate, January 2, 1932, p. 2. 
World War II. NAACP Executive Secretary Walter White toured the country speaking of post-war racial discord including congressional infighting over fair employment legislation. White attended a seven-state regional conference where a policy denouncing workplace segregation and discrimination of trained Black students. ${ }^{49}$ White suggested that "Segregation is the core of the so-called race problem in America." ${ }^{50}$ Speaking to the City Club of Portland, White explained the position of the NAACP and "urged support for a fair employment practices law." ${ }^{51}$ White approved of a fair employment practice bill that President Harry S. Truman was trying to pass through Congress. However, it did not pass. Because of the failure, Truman signed Executive Order 9980, which regulated fair employment practices within the federal government. ${ }^{52}$

The Portland NAACP dealt with fair employment practices as they worked alongside unions and business owners in order to bring the issue to the attention of state and local leaders. The NAACP president, Dr. Robert N. Joyner Jr., spoke in January of 1946 on political action and race relations at the USO on North Williams Avenue. A month later, Walter White visited Portland and spoke about the national fight for fair employment practices and Oregon's role in the legislative process. ${ }^{53}$ White explained that employment discrimination needed to be addressed in the "dawning atomic age" or the

49 "Negroes Rap Dixie Revolt, Renew Racial Equality Bid," The Oregonian, March 22, 1948, p. 8.

${ }^{50}$ Ibid.

51 "Race Bigotry Draws Attack," The Oregonian, p. 4.

52 "Harry S. Truman: Executive Order 9980," July 26, 1958. Online by Gerhard Peters and John T. Woolley, The American Presidency Project Accessed February 23, 2016, http://www.presidency.ucsb.edu/ws/?pid=78208.

53 "NAACP Head To Speak Here," The Oregonian, January 16, 1946, p. 11. "Racial Peace Declared Key," The Oregonian, February 7, 1946, p. 11. 
world would face destruction through future wars. ${ }^{54}$ Although the local NAACP chapter pursued fair employment practices, their strength was in fighting discrimination and rising racial tension.

\section{"Race Bigotry"}

"There are grave flaws in our democracy and they are increasingly being used against us." 55

On June 3, 1932, Southern Pacific Railroad dining car steward F. T. Sullivan was found beaten with a fractured skull in a sleeping car bunk while the train was stopped in Klamath Falls, Oregon. He later died of his injuries in San Francisco, California. Theodore Jordan, "negro ex-convict," was detained for questioning before allegedly confessing to beating and robbing Sullivan after being released from prison a few days earlier. ${ }^{56}$ Deputy District Attorney Van Vactor believed he found a suspect for the beating of the White dining car steward and moved quickly to bring Jordan to justice.

The trial was prompt. Jordan was convicted and sentenced to death by hanging, scheduled for April 1933. Prosecutors changed Sullivan's occupation from a dining car steward to railroad worker to a train conductor during the trial which, no doubt, changed the severity of the crime in the eyes of the jury. The only incriminating evidence was a coerced confession obtained the day after the body was found. Jordan testified to a beating he took by officers who forced him to sign seven confessions in addition to

54 Ibid.

55 "Race Bigotry Draws Attack: Speaker Declares Soviets Benefit," The Oregonian, November 27, 1948, p. 4.

56 "Negro Admits Attack," The Oregonian, June 6, 1932, p. 2. 
crossing paths with W. G. Chandler, a Southern Pacific Railroad detective, with whom Jordan had had prior confrontations in 1924 and 1928. ${ }^{57}$ However, Mrs. Callie M. Timms testified that Jordan came to her house and explained that he was involved but he was not the person who beat Sullivan, stating "He did not do it but he was in the middle of it." 58 Little information was reported during the trial, but on December 14, 1932, Jordan was moved to the state penitentiary in Salem, Oregon, suffering from superficial flesh wounds which were reported as self-inflicted. ${ }^{59}$

Jordan's execution was stopped by an Oregon Supreme Court decision on appeal in April 1933. However, he was ordered to stand trial again and newspapers reported he would hang for the murder of Sullivan. ${ }^{60}$ The trial date was set for September 15, in Salem. The International Labor Defense, along with the NAACP and other civic organizations, organized a performance prior to the trial which depicted the inaccuracies and circumstantial evidence which plagued the first trial. The performance was met with some skepticism. However, most attendees believed it changed public sentiment to sympathy for Jordan. ${ }^{61}$ Although the play was designed to pay for an appeal, it also benefited Jordan in the court of public perception. However, it did not sway the state Supreme Court, who issued its decision on November 9.

57 "Negro Under Death Verdict Made Oregon Cause Celebre," The Oregonian, May 3, 1934, p. 4. State v. Jordan 146 Or. 504 (Or. 1934).

${ }^{58}$ Ibid.

59 "Negro Reaches Prison," The Oregonian, December 15, 1932, p. 11.

60 "Labor Defense to Meet," The Oregonian, June 25, 1933, p. 11. "Jordan Files Appeal," The Oregonian, June 3, 1933, p. 10. "Defense Group to Meet," The Oregonian, September 13, 1933, p. 11.

61 "Benefit Play Announced," The Oregonian, April 6, 1933, p. 7. 
"Death Sentence Upheld: Slayer of Pullman Conductor Loses Appeal," read the November 9 headline. Justice Robert S. Bean wrote a statement upholding the Klamath Falls decision, effectively sending Jordan back to death row. ${ }^{62}$ Immediately, International Labor Defense and NAACP attorney Irvin Goodman prepared for another appeal, announcing petitions against the five-to-two decision and maintaining Jordan was convicted on circumstantial evidence by a biased jury. He expected lawyers and ministers throughout Oregon to sign the petition and sent for Jordan's mother from Oakland in an attempt to gain sympathy from the court with a grieving parent. ${ }^{63}$ Intensified by racerelated tension, civic organizations continued to hold protests, gatherings, plays, and dances as a way to raise money for Jordan's appeal. His defenders coined the phrase,

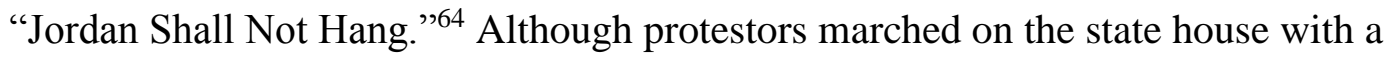
resolution for Governor Meier urging Jordan's unconditional and immediate release, the governor did not act. The protests continued, with thousands of postcards from around the nation demanding the release of Jordan flooding the governor's office. ${ }^{65}$

Months of work by the International Labor Defense and NAACP attorney Irvin Goodman paid off for Jordan in July, 1934. Jordan had lost two Oregon Supreme Court

62 "Death Sentence Upheld: Slayer Of Pullman Conductor Loses Appeal," The Oregonian, November 10, 1933, p. 8.

63 “Jordan Appeal Planned: Petitions To Be Prepared," The Oregonian, November 11, 1933, p. 12.

64 "New Deal Given," The Oregonian, February 14, 1934, p. 6. "Death Penalty Fought: Demonstrators Oppose Hanging of Confessed Slayer," The Oregonian, February 21, 1934, p. 14.

65 "Death Sentence Protested," The Oregonian, April 25, 1934, p. 16. "Negro Under Death Verdict Made Oregon Cause Celebre," The Oregonian, 4. "Woman Writes Oregon Jailed Innocent Man," Sacramento Bee, September 12, 1951, p. 22. "Pleas Saved Life; Jordan Now Free," Omaha World-Herald (Omaha, Nebraska), May 25, 1954, p. 14. 
appeals and faced an upcoming death sentence in Salem on August 1. However, two years after Jordan's conviction, Governor Meier granted him clemency, commuting his sentence to life in prison. Meier created a committee to reviewe the case and reported, "We think that there was some prejudice against the defendant because he is a Negro and that this had a tendency to prevent a fair and impartial prosecution." ${ }^{\circ 6}$ Although the report suggested racial bias as a reason to overturn the sentence, the governor had grown tired of the protests put on by various organizations. ${ }^{67}$ Either way, the clemency granted to Jordan stopped the protests until 1951, when the NAACP urged state officials to free Jordan altogether.

In May 1951, Oregon Penitentiary officials intercepted a letter written to Jordan from Alice Gilbert Borden of Chicago, Illinois. The letter stated Borden knew of Jordan's innocence because her husband, Sears Gilbert, had confessed, explaining how he had snuck into the railroad car and beat Sullivan to obtain keys to a lock box holding $\$ 300$. $^{68}$ Gilbert had testified against Jordan in the 1932 trial, stating he refused to help Jordan in the proposed hold up. Unfortunately, Gilbert died in 1937 and there was no way to corroborate Borden's story. She stated, "I have pondered over it 10 years and can no

66 “Jordan and Riley Saved From Death: Meier Commutes Sentences to Life Imprisonment," The Oregonian, July 3, 1934, p. 5. Wallace Turner, "Chicago Police Report Blasts Hope of Oregon Prisoner for Freedom," The Oregonian, September 16, 1951, p. 22.

67 Ibid.

68 "Woman Signs Affidavit Stating Life-Termer Innocent Of Murder," Plaindealer (Kansas City, Kansas), September 21, 1951, p. 1. Sears Gilbert and Alice Borden had a fight wherein Alice shot Sears. Fearing death was imminent and wanting to clear his conscience, Sears confessed to the murder of Sullivan. 
longer rest peacefully knowing Jordan is imprisoned for a murder he did not commit."69 Borden had attended the trial and insisted Gilbert's testimony was the sole reason Jordan was in prison. ${ }^{70}$

Local NAACP officials urged the immediate release of Jordan after seeing the Borden letter. NAACP representative Annie I. Hughes delivered a statement to Governor Douglas McKay which read, "We know that many persons have been released from the penitentiary who were sentenced for life terms after having served little more than seven years." The group argued Jordan was held for longer due to racial bias unlike White prisoners who gained parole after serving as little as seven years. ${ }^{71}$ Prison officials responded that Jordan's continued confinement was due to his troublesome behavior. For example, Jordan took part in a prison riot shortly after escaping the death penalty. He and another inmate hid in the chapel after the riot started and opened cells for other inmates in an escape attempt. ${ }^{72}$ Although Jordan began studying at the University of Oregon through extension courses after the prison riot, he continued to give "officials a lot of trouble."73 He was involved in setting fires which damaged flax sheds estimated at five hundred thousand dollars that placed him in solitary confinement. Jordan explained, "Sure I caused them trouble. I am innocent and I want out of here."74

69 “Woman Writes Oregon Jailed Innocent Man," Sacramento Bee, 22.

70 "Woman Signs Affidavit Stating Life-Termer Innocent Of Murder," Plaindealer, 1.

71 "Pardon Asked for Slayer: Racial Prejudice Charged in Plea," The Oregonian, April 9, 1952 , p. 8.

72 "3 Convicts Shot in Prison Riot: One Man Dead as Result of Salem Disturbance," The Oregonian, August 1, 1936, p. 2.

73 Turner, "Chicago Police Report Blast Hope," 22. "Parole Seen For Jordan," The Oregonian, May 13, 1954, p. 1.

74 Ibid. 
The work of civil rights groups paid off in 1954, when Jordan gained parole after serving 22 years in prison. In May, H. M. Randall, director of the state parole and probation board, announced tentative action to parole Jordan. The parole board came to a unanimous decision, describing Jordan as a model prisoner over the last several years. While working on a prison farm outside of Salem as a gasoline pump operator after gaining substantial education. ${ }^{75}$ His hope in gaining the education was to become a civil engineer after only receiving a fourth grade education before entering prison. ${ }^{76}$ Two weeks later Jordan was released with the help of NAACP attorney Goodman and Reverend T. M. Baxter, the penitentiary chaplain. ${ }^{77}$ Organizations had worked to free Jordan beginning in 1933, and by 1954, they considered his release a huge success of national importance with it being reported from Oregon to California to Nebraska and Boston. Although Jordan's clemency and freedom demonstrated success, it also increased stress between the Black and White communities. The Wardell Henderson case would provide more ammunition for the Black community.

On Christmas Eve 1945, United States Army Sergeant Wardell H. Henderson was pulled over in a stolen vehicle owned by murdered Vanport butcher Walter Poole. Under duress, Henderson confessed to the murder of Poole and was arrested. He was convicted in 1946, and sentenced to death by lethal injection. In 1948, the NAACP began a campaign to commute Henderson's sentence to life in prison. Once again NAACP

\footnotetext{
75 “Oregon Convict Given Freedom After 22 Years," The Seattle Times, May 25, 1954, p. 7.

${ }^{76}$ Leslie Tooze, “48-Year-Old Lifer Freed After 22 Years in Prison,” The Oregonian, May 25, 1954, p. 1.

${ }^{77}$ Ibid.
} 
attorney Irvin Goodman represented Henderson, stating, "I have made a study of the case... and I am convinced there are grave doubts as to his guilt of the crime charged." Goodman insisted the confession was coerced and Henderson was convicted on circumstantial evidence. A newly acquired statement from the jury foreman advocated for clemency and a commuted sentence. However, cooperating organizations began fighting the case after learning other murderers, "some of an 'unusually atrocious character,", were not sentenced to death, again adding to the growing race-related stress. ${ }^{79}$

A week after Goodman's statement, Governor John H. Hall announced he would not commute Henderson's sentence, adding he was convicted by a jury of his peers after incriminating testimony. Hall refused to order a new case, claiming that Henderson, nor anyone connected to the case, ever claimed prejudicial treatment. Hall concluded, "Neither has anyone established that the question of racial discrimination was in any way connected with the case. ${ }^{\prime 80}$ After hearing the news, Edwin C. Berry of the Urban League likened the future execution to a lynching while Urban League president David Robinson publicly denounced the decision, suggesting prejudice among the jurors. ${ }^{81}$ Goodman furiously declared, "The governor 'has thrown in the waste basket' affidavits obtained from two jurors who said the jury's decision was influenced by racial prejudice." 82

78 "100 Portland Attorneys Ask Commutation for Slayer," The Oregonian, January 14, 1948, p. 10.

${ }^{79}$ Ibid.

80 "Hall Denies Clemency for Killer: Governor Recalls 9-Day Court Trial, Other Legal Steps," The Oregonian, January 21, 1948, P. 1.

81 "Strong Protest Entered on Henderson Decision," The Oregonian, January 21, 1948, p. 10.

${ }^{82}$ Ibid. 
Goodman insisted the Oregon constitution permitted the governor to commute the sentence without trial. He described the discrepancy between White-convicted murderers being sentenced to life in prison while Black-convicted murderers were sentenced to death. Lastly, Goodman stated he had obtained sworn affidavits from two jurors who said Henderson "was sent to the gas chamber solely because he is a negro," which angered the Black community. ${ }^{83}$

The president of the Oregon Prison Association, Helen A. Catlin, requested a meeting with the governor to discuss Henderson's clemency on January 21, 1948. However, when she invited Goodman to attend, Governor Hall refused to meet with the group on the grounds he had previously ruled and that "such a meeting would be a "waste of time." ${ }^{\circ 4}$ Catlin expressed shock at the governor's decision and urged him to reconsider, citing the affidavits. She argued with the governor, stating he did not have adequate time to read the affidavits. He responded, "I did receive and read them. They do not prove the existence of race prejudice. They name no names, and neither affidavits, asked for executive clemency in the case. My mind is made up. ${ }^{" 85}$ In an attempt to circumvent the governor's decision, the NAACP called on Judge Frank L. Lonergan to overturn to the ruling, but Lonergan advised the only intervening person was the governor. He explained it was out of his hands but if some motion had been brought up at

\footnotetext{
83 Ibid.

84 "Hall Refuses Conferences On Issuing Stay for Killer," The Oregonian, January 22, 1948, p. 9.

${ }^{85}$ Ibid.
} 
trial he could have set the verdict aside. On January 23, 1948, Oregon put Wardell Henderson to death by lethal injection. ${ }^{86}$

Police brutality and overreach continued to exacerbate racial tensions as more African Americans were subjected to harassment by law enforcement. On April 3, 1946, Earl Smalls of Vanport was escorted home by two Black police officers to have his apartment opened. Smalls was a veteran as well as a Kaiser Shipyard worker. While in route to his home, one of the officers called Earl "sonny boy," to which he took offense. Earl asked the deputy to call him by his given name, at which point the deputy became abusive. Earl reported this behavior to the Vanport Sheriff's office but was met with an ambivalent response, so Earl continued to the Portland Court House and reported the incident to the sheriff. After Earl returned home, the two deputies arrived and took him to the Vanport police station and severely beat him for reporting them ${ }^{87}$ He was thrown into jail on charges of drunken and disorderly conduct and left there until morning. Due to the severe beating, one eye needed to be treated by a doctor immediately. His cellmate advised him to plead guilty to the charges in order to see a doctor quickly. Fearful of more retribution, and wanting to get his eye looked at, Earl pled guilty to the charges and was released. After leaving jail, his eye became more painful and he lost his eyesight. He immediately went to the Veterans Hospital in Portland where he received little attention from the eye specialist, who told him he had blood in his eye and he would either recover or lose his sight but not to worry about it. On April 6, Earl crossed the river to Vancouver

\footnotetext{
${ }^{86}$ Oregon Death Index, "Wardell H. Henderson," January 23, 1948 Marion, Oregon, 882. 87 “MSSULP 1946 Meeting Minutes," Oregon Multicultural Archives, 10.
} 
and was examined by Dr. Ullman at Permanente Hospital. Ullman treated Earl's eye and stomach, keeping him in the hospital for four days. ${ }^{88}$

Smalls contacted the Urban League to inquire about help. Berry encouraged him to seek the help of other agencies working on race relations in Portland to set up meetings with Sheriff Martin T. Pratt. Berry explained this case needed to be handled carefully because the officers who beat Small were also African American. He suggested the case not take a racial angle but rather an angle of police brutality. Other Urban League members contended the incident was not isolated and demonstrated the need for qualified police officers and racial tolerance training. Urban League President David Robinson suggested the Urban League coordinate its efforts with other agencies at which point the case was turned over to the NAACP, which was better equipped to deal with civil cases focused on police brutality. ${ }^{89}$ No other information is reported on the Small's case, but it provides another instance of police brutality and therefore tension between the two communities.

\section{"Segregation in Public Places"}

"I would never operate a business that I would have to cater to Negroes because I do not like them and I don't want to contaminate my white people by having them to rub shoulders with a Negro. "90

\footnotetext{
${ }^{88}$ Ibid., 10.

${ }^{89}$ Ibid.

90 “Grocer Refuses to Sell to War Workers: Alberta Proprietor Says He Will Never Sell Food to Negroes," The People's Observer, February 28, 1945, p. 1.
} 
In 1948, two Willamette University students kicked off a push for equality within public accommodations in Portland. Their efforts culminated in the passage of a civil rights bill in 1953. In February 1948, Mary Elizabeth Tedford and Alice Turtledove, journalist for the Willamette University Collegian, asked Governor Hall about his own racial bias in regards to the Henderson trial. He explained racial tolerance courses were not necessary in Oregon because he did not see a problem of racial intolerance. ${ }^{91}$ The NAACP immediately responded in amazement at the governor's views, especially in regards to the Henderson case. "We are amazed that the governor of our state is unaware of the discriminatory practices directed at persons of racial minorities throughout Oregon," read their statement. NAACP leaders promised to provide "proof of racial injustice" in Portland, and concluded, "We earnestly hope that after such a course on racial understanding he will have the courage to take the necessary steps to eliminate racial inequality in Oregon.",92

The proof of racial injustice came from a "Discussion of Rumored Discrimination at University of Oregon," which had taken place in 1946. Urban League officials had learned that African American women were living in segregated dormitories. Dr. Luther Cressman, an activist and anthropology professor, spoke with University of Oregon president Dr. Harry K. Newburn to get a sense of the situation. The president expressed tolerance and pledged to investigate the matter further. However, Urban League Executive Secretary Edwin C. Berry was not satisfied and sought to visit with the

91 "Hall Remarks Cause Shock: Race Situation Termed Unknown," The Oregonian, February 15, 1948, p. 19.

92 "Hall Remarks Cause Shock," The Oregonian, 19. 
university president and other officials personally. ${ }^{93}$ In June, Newburn assured Berry he did not want to see segregation on the campus, but quoted a university rule in which Black and White girls were "prohibited from occupying the same room."94 Berry believed Newburn thought the rule was adequate and needed no change. However, no similar rule existed in the state laws. ${ }^{95}$ The league surveyed other Oregon colleges housing policies but received few responses. The ones they did receive showed no segregation within the dormitories. This example provided proof of segregation and discrimination on one Oregon campus and led to increased frustration for the lack of civil rights laws which contributed to growing tensions.

In October 1950, the Oregonian reviewed Seattle's civil rights law, attempting to demonstrate its effectiveness in reducing racial tension. Reporter Mervin Shoemaker reported that Seattle's anti-discrimination law focused on accommodations, restaurants, and grocery stores. ${ }^{96}$ Shoemaker explained that Seattle's law was effective in creating programs of cooperation between Black and White Americans through education and promotion of civil rights. He described the work of the Seattle branch of the NAACP in passing the law and their patience in getting it to work for them. ${ }^{97}$ Shoemaker concluded, "Seattle's experience can be encouraging to civil rights workers in Portland. But it can

93 “MSSULP 1946 Meeting Minutes," Oregon Multicultural Archives, 8. Berry finally met with president Newburn after several weeks of repeated phone calls and letters. ${ }^{94}$ Ibid., 13.

95 Ibid.

${ }^{96}$ Mervin Shoemaker, "Law Bars Race Discrimination in Washington," The Oregonian October 9, 1950 p. 11.

${ }^{97}$ Ibid. Shoemaker illustrated Seattle's accomplishments were self-affirming as Whites took pride in what they had accomplished for African Americans. 
give them warning too, that patience counts as much as push in this business. After five years of civic endeavor and a strong law, Negroes will still be receiving over-salted food in some places." 98 His call for patience would become a haunting reminder to civil rights activists of how deeply racial prejudice was imbedded in the culture of Portland.

The Washington law eased general racial tensions in the Seattle area, according to Shoemaker. He explained how race relations were impacted by the law in a follow up article. One African American told him, "The race relations climate in Seattle is getting better." 99 Shoemaker suggested the change in race relations was due to more contact with Black Americans. He also believed cooperation with the Civic Unity Committee and business owners allowed for less friction between state officials and business owners. However, it was reported that some restaurants discouraged Black trade by using tactics such as over seasoning, under cooking, or long delays in food preparation. ${ }^{100}$ Although some instances were reported, Shoemaker believed the law led to an easing of racial bias in Seattle generally. He implied the way to ease race-related stress in Portland was to pass a civil rights ordinance that covered public accommodations.

The NAACP struggled to ease racial tension between the Black and White communities in Portland. The local branch worked on banning The Birth of a Nation which drew large crowds throughout Oregon. Individual cases of discrimination and excessive force perpetrated by Portland police added to the already tense situation

\footnotetext{
98 Ibid.

${ }^{99}$ Mervin Shoemaker, "Law, Civic Effort Slowly Ease Seattle Racial Bias," The Oregonian October 11, 1950 p. 16.

${ }^{100}$ Ibid.
} 
surrounding unemployment and housing segregation. The organization took part in national demonstrations. However, their strength was rooted in the local community where they held more authority and understood local concerns. After years of fighting prejudicial behavior in Portland, the NAACP collaborated with other community organizations and identified one factor in easing racial tension: equality in public accommodations. The difficulty would be reaching a broader interracial audience in support of the needed legislation. As the next chapter shows, the City Club of Portland would help to do this. 


\section{Chapter Two}

\section{"The Conscience of a City"1}

"To inform its members and the community in public matters and to arouse in them a realization of the obligations of citizenship. "2

On July 20, 1945, the City Club of Portland committee on race relations published a report entitled "The Negro in Portland."” City Club members were either elected or asked to join the committee. In some ways the committee was diverse; it was comprised of a lawyer, journalist, clergyman, rabbi, insurance salesman, grocery store owner, and the president of the YMCA. On the other hand, all were longtime members of the organization and all were White. Dr. DeNorval Unthank, the second African American physician in Portland, was the exception. He was also the exception to the membership of the City Club which, until his nomination a year and half earlier, was a de facto racially segregated organization. The City Club committee is significant because it demonstrates interracial cooperation focused on race relations in the post-war period. Moreover, it illustrates the beginning of a concerted effort to educate city residents, who were overwhelmingly White, on the topic of race. The City Club report drew on research presented in previously published National Association for the Advancement of Colored People (NAACP) and Urban League of Portland reports. But, the City Club report reached an audience that may have not been familiar with those earlier reports. ${ }^{4}$ In this

\footnotetext{
${ }^{1}$ Ellis Lucia, The Conscience of a City: The City Club of Portland Golden Anniversary 1916-1966 (Portland: City Club of Portland, 1966).

2 "The Negro in Portland," Portland City Club Bulletin July 20, 1945.

${ }^{3}$ Ibid.

${ }^{4}$ The City Club membership consisted of white professionals who possibly did not receive information from the NAACP or the Urban League. Although membership
} 
way, the City Club became a vehicle of validity for the information Portland's early civil rights leaders were trying to circulate. And because he held membership in the NAACP and Urban League, Dr. Unthank was an essential bridge between the African American community and the City Club.

This chapter focuses on two City Club reports, one published in 1945 and the other in 1953, to examine the role of the City Club in Portland's early Civil Rights movement. The two reports demonstrate the shift from simply reporting on the scope of the city's discrimination to identifying and advocating solutions to that discrimination. The first report responded to shifting wartime demographics. African American men and women flooded into Portland shipyards as war production boomed between 1941 and 1944, increasing the Black population from 2,100 to 22,000. The second report, five years later, was a response to the rising racial tension manifested from a quickly increasing African American population, crime, police brutality, and racial injustice. This report identified a solution to discrimination and supported the Civil Rights ordinance proposed by the City Council.

The City Club formed a committee on race relations in 1944; its primary purpose was the creation of the 1945 report. No meeting minutes exist from the yearlong study, which is unusual. Within their archives, the City Club has minutes from other committees from this period. What does exist are various letters to other organizations, research statistics, newspaper accounts, and copies of form letters thanking participants. This

crossed over organizations, the information may not have been available to the general City Club membership. 
thesis uses newspaper articles, biographical information of committee members, and the published City Club reports to examine the broader scope of participation among Portland's business community. My study also demonstrates the shift between highlighting a growing problem in Portland in 1945 and finding a solution by 1950 . Both reports highlight the intergroup collaboration, as well as interracial cooperation present in Portland's early Civil Rights struggle. The City Club reached a broader audience which likely had not seen the information the NAACP and Urban League was producing. The organization also desegregated during this time, admitting its first African American member in $1943 .^{5}$ Therefore, both reports are significant in clarifying the racial tension and then providing solutions more readily acceptable to Portland's white citizens. As a result, this chapter demonstrates the importance of intergroup collaboration, interracial cooperation, and appealing to a broader audience to gain support for civil rights legislation and solutions.

\section{"Forward Looking Men"}

"These young men, well-educated and eager to do things were dissatisfied with the way things were going in their town. They were especially critical of the operation of the city's public institutions and ways of government."6

\footnotetext{
${ }^{5}$ The City Club of Portland was open to Jewish membership prior to 1943 . However, the organization membership was limited to white males. The City Club desegregated in 1943 when it admitted Dr. DeNorval Unthank, its first African American member. However, the organization continued to be gender segregated until 1973, when membership was opened to women after weeks of protest by feminist organizations. For further information about the opening of the City Club to women, see: Tara Watson and Melody Rose, "She Flies with Her Own Wings: Women in the 1973 Oregon Legislative Session," Oregon Historical Quarterly, (Spring 2010), 38-63.

${ }^{6}$ Lucia, The Conscience of a City, 10.
} 
Civic minded business owners founded the City Club of Portland in 1916 to intervene in "the operation of the city's public institutions and ways of government." Members held the organizations first meetings at the Hazelwood Confectionery and Restaurant. Those first members included attorneys, architects, bank clerks, foresters, doctors, and salesmen, none of which belonged to Portland's most elite families. ${ }^{7}$ Dissatisfied with the existing social organization's that seemed to do little for the community, members met together to discuss new ideas, which gradually took on "serious undertones." The City Club found its niche among Portland's fraternal clubs by reporting on public issues affecting the city.

The organization began holding regular meetings with ten members, quickly increasing to twenty by the end of 1916. Membership grew rapidly, soon boasting over one hundred businessmen. However, U.S. involvement in World War I decreased membership in the second year and all meetings were suspended by 1918. After WWI, membership topped 500 "forward-looking men" interested in civic duty. ${ }^{8}$ Steady growth over the next two decades made the City Club one of the most successful organizations in Portland with more than 2000 members by $1945 .{ }^{9}$ Gradually, the City Club became the organization reporting on important civic issues. Waterfront shipping and shipbuilding were the first two issues undertaken. The organization lobbied to stop taxation on local ships. $^{10}$

\footnotetext{
${ }^{7}$ Ibid., 9.

${ }^{8}$ Ibid., 18.

${ }^{9}$ Ibid., 35.

${ }^{10}$ Ibid., 16.
} 
The City Club began building its reputation as a community watchdog in the 1920s, reporting on social problems affecting the public. ${ }^{11}$ By 1945 , the Club had reported on 280 civic issues, including city and state government, transportation, health and cultural affairs. According to the organization's own history, City Club reports gave "the public a voice in city governance." 12 The Oregonian shared the sentiment stating, "The City Club is the best organization of its kind existing anywhere that we are intimately acquainted. It has been a tremendous influence in Oregon." ${ }^{\prime 13}$ The City Club demonstrated significant influence by delivering valued reports to city leadership. The organization became important to White citizens by providing reliable research on social issues. However, up to the U.S. entrance in WWII, the City Club held little credibility in Portland's minority communities.

That would change with the nomination of the club's first African American member, Dr. DeNorval Unthank, in 1943. The nomination was a "tempest in a teapot."14 First nominated on December 3, Unthank was not introduced as a member until December 30, an unusual delay as "Dr. Unthank possessed stature and the kind of public spirit that the City Club enjoyed." A significant leader in the Black community, Unthank fit the professional make-up of the City Club. However, several members opposed his nomination. The Board of Governors split eleven to three in favor of accepting Unthank but suggested it would "hurt the City Club" to break the club's unwritten rule that kept

\footnotetext{
11 Ibid., 51.

12 Ibid., 35.

13 "Same Resolution," The Oregonian February 6, 1945, 4.

${ }^{14}$ Lucia, The Conscience of a City, 63.
} 
the organization segregated. In an unprecedented action, the organization polled 213 club members to determine how the membership would respond to racial integration; 166 voted in favor while 47 opposed opening membership to Unthank. ${ }^{15}$

Forward thinking men looking to expand the reach and diversity of the City Club had nominated Dr. Unthank for membership. Henry Gunn, acting City Club president, served as the Portland Public Schools superintendent until 1944, when he took the same job in Eugene, Oregon. Gunn received his master's degree at the University of Oregon and his doctorate at Stanford. In 1947, Dr. Gunn became the president of the Oregon College of Education in Monmouth, Oregon and in 1950, accepted the position of superintendent of the Palo Alto school district in California. ${ }^{16}$ Gunn led multiple organizations while in Portland, including the City Club. Richard Steiner became president of the City Club for the term 1951-1952. Steiner was reverend of Portland's First Unitarian Church after being pastor of Grinnell College in Iowa. He served as reverend for thirty-five years, retiring after reestablishing the church in the wake of a fire. Melvin Arnold was vice-president of the City Club and a journalist at the Oregonian. In 1944, Arnold was offered a job at Standard Oil, moving from Portland to New Jersey with his wife and baby. Later Arnold became the editor of the Harper \& Row publishing company. ${ }^{17}$ A young member of the City Club, Arnold showed promise as a future leader

\footnotetext{
15 Ibid., 63.

16 "Henry Gunn," http://www.wou.edu/provost/library/archives/university/presidents/Gunn.php. Accessed June 1, 2014. 17 "Melvin Arnold" Harvard Library accessed June 1, 2014, http://oasis.lib.harvard.edu/oasis/deliver/ div00204
} 
and activist. His nomination of Unthank marked his first of many contributions to the Civil Rights Movement. He later worked with Dr. Martin Luther King, Jr. on his autobiography. ${ }^{18}$

The nomination of Unthank challenged the unwritten rules of racial segregation within the organization. Although bylaws did not overtly endorse segregation, Unthank was the first person of color nominated for City Club membership. Gunn, Arnold, and Steiner believed Unthank fit the mission of the City Club. Furthermore, they viewed Unthank as a bridge between the organization and the Black community. Adding him as a member lent credibility, authority, and validity to the organization and its future reports on city race relations.

\section{"Highly Recommended"19}

"During the nearly 35 years of practice in Portland, Dr. Unthank has given freely of his time and counsel to youth as well as newly married couples. He has freely advised and assisted widows and elderly persons in securing their pensions, welfare assistance, etc. "20

DeNorval Unthank was born December 4, 1899, one of eight children in Allentown, Pennsylvania. After the death of his mother, when he was nine, DeNorval went to live with his uncle, Kansas City physician Thomas Unthank. ${ }^{21}$ Unthank attended school in Kansas City before being accepted to the University of Michigan, where he worked part-time jobs to defray the cost. The majority of the time he was a houseboy at a

\footnotetext{
${ }^{18}$ Ibid.

${ }^{19}$ Beatrice Morrow Cannady, “A New Doctor," Advocate, January 25, 1930 p. 1.

${ }^{20}$ Verdell Rutherford, "Personal Sketch," Rutherford collection, Portland State University Special Collections, p. 4.

${ }^{21}$ Ibid., 1.
} 
fraternity and compensated with a room and waited tables at a sorority in exchange for meals. Unthank also worked at Swift and Company, a beef rendering plant in Kansas City, until 1920, when he graduated. ${ }^{22}$

Unthank began medical school in 1922 at Kansas University. However, due to segregation policies, he was only able to complete two years. In the fall of 1924, Unthank entered Howard Medical School, receiving his medical degree in $1926 .{ }^{23}$ He spent two years in training at an eye, ear, nose, and throat facility, leading to a certificate in 1928 , while also volunteering at the Kansas City tuberculosis clinic. He also worked at the Well Baby Clinic in the Florence Crittenton Home for Negroes, delivering and attending to babies until 1929. On January 14, 1929, Dr. Unthank married Thelma Rainey Shipman in Omaha, Nebraska. ${ }^{24}$

The Unthanks arrived in Portland in early 1930. The Advocate reported his arrival stating, "Dr. Norvell [sp] Unthank of Kansas City arrived in Portland to reside and practice his profession, medicine." As the only Black physician in Portland throughout the 1930s, Unthank's arrival was important to the African American community. ${ }^{25}$ Due to segregation, African Americans did not have access to treatment in area hospitals. Unthank made house calls day or night, serving the minority community, as well as poor white families. ${ }^{26}$ In a 2010 oral history interview his daughter Leslie Unthank

\footnotetext{
22 Ibid.

23 Ibid.

24 Ibid.

25 "Portland Has New Doctor," The Advocate January 30, 1930.

${ }^{26}$ Rudy Pearson. “Unthank, Dr. DeNorval (1899-1977),” Blackpast.org (2011): accessed May 11, 2014, http://www.blackpast.org/aaw/unthank-dr-denorval-1899-1977.
} 
remembered making house calls with her father in May 1948, in Vanport, Oregon, and being told to leave when the flooding began. ${ }^{27}$

Dr. Unthank started Portland's first Negro "well baby" clinic and served on the boards of the Oregon Medical and Multnomah County Medical Associations. ${ }^{28}$ Local civil rights activist and NAACP executive board member Verdell Rutherford wrote of his service, "Dr. Unthank has given freely of his time and counsel." ${ }^{29}$ Unthank spoke on radio and at local churches, building his reputation within the Black community through his medical expertise. The Advocate covered the doctor's public talks, such as one on January 30, at Bethel A.M.E. Church on the topic of "How to Keep Well and Strong."30 In the spring of 1931, Advocate owner and editor Beatrice Morrow Cannady invited Unthank to contribute a column on topics from curing the common cold to fads and superstitions. ${ }^{31}$ Unthank developed a reputation within the African American community both as a physician and as an activist. In an oral history interview conducted in 2010 ,

${ }^{27}$ Leslie Unthank Transcript," last modified May 7, 2010, http://www.eliotoralhistories.com/transcripts.html. The flood happened after a railroad tie punctured a hole in the dike separating the Columbia River from the Kaiser housing project Vanport. For further reading please see Carl Abbott, Portland in Three Centuries (Corvalis: Oregon State University Press, 2011), 123-125.

28 “Clinic Examines 20 Negro Babies," The Oregonian April 21, 1939.

${ }^{29}$ Verdell Rutherford. "DeNorval Unthank M.D. Biographical Data," Portland State University Special Collections, p. 4.

30 "Negro Doctor to Speak at Bethel Saturday Nite," The Advocate January 30, 1930.

${ }^{31}$ Kimberly Mangun. A Force for Change: Beatrice Morrow Cannady and the Struggle for Civil Rights in Oregon, 1912-1936 (Corvallis: Oregon State University Press, 2010), 48. 
Oregon Senator Avel Gordly made it a point to tell an interviewer that Dr. Unthank delivered her, demonstrating Unthank's importance to the Black community. ${ }^{32}$

Discrimination plagued Unthank's early career. Black dentist Elbert Booker and Unthank tried to open an office together but were told by the landlord that other tenants objected. After being evicted, Dr. Unthank was forced to work from his home. He relocated three more times, finally settling on the Arata Building two years later. ${ }^{33}$ If locating an office was difficult, finding a home was almost impossible.

"Vandals Break Windows In Doctor's Home" declared The Advocate headline July 4, $1931 .{ }^{34}$ On the night of June 27, 1931, Dr. Unthank and his wife Thelma returned to find four windows in their home broken by rocks, the second time in two months their residence was vandalized. The neighborhood association, Westmoreland Protective League, convened to ask the Unthanks to move, offering to pay the mortgage and moving fees. Unthank demanded the organization pay upwards of $\$ 700$, which the league found exorbitant. ${ }^{35}$ Tempers flared between neighbors in late June, and Thelma Unthank allegedly told one of them, "If I had a gun I'd shoot you." Thelma was charged with threatening to commit a felony. ${ }^{36}$ The incident provided the Unthanks firsthand experience with housing discrimination common in Portland at the time. ${ }^{37}$

\footnotetext{
${ }^{32}$ Avel Gordly and Patricia Schechter, Remembering the Power of Words: The Life of an Oregon Activist, Legislator and Community Leader (Corvallis: Oregon State University Press, 2011), p.?

${ }^{33}$ Mangun, A Force for Change, 152.

34 "Vandals Break Windows In Doctors Home," The Advocate July 4, 1931.

35 "Negro Asked to Move," The Morning Oregonian April 30, 1931.

36 “Community Row Settled," The Morning Oregonian July 18, 1931.

37 The issues of redlining and housing segregation have been well covered by several historians. It is not my intention to regurgitate the same evidence which has been used
} 
The vandalism caught the attention of the NAACP and a special committee formed to help Unthank protect his residence. Police officers patrolled the area each hour and a patrolman watched the house while the Unthanks were gone. ${ }^{38}$ Unwelcome in their new neighborhood, the Unthanks moved into the small home of Henrietta and William Marshall in North Portland. ${ }^{39}$ A friend of the family, Otto Rutherford stated, "They harassed the hell out of that man and finally he moved." Another friend, Kathryn Bogle, insisted he was being driven out because neighbors objected to African Americans living in the upscale Westmoreland community. ${ }^{40}$ Thirteen months later the Unthanks moved to the Montavilla neighborhood in east Portland, which had a higher concentration of African American homeowners than the Westmoreland neighborhood. ${ }^{41}$

Dr. Unthank joined the NAACP after the housing incident; and in 1932, he became vice-president, later serving as president. His work focused on housing segregation, labor union discrimination, and poor working conditions for African Americans. Unthank prepared reports and presentations documenting the African

many times. For further information see: Rudy Pearson, "'A Menace to the Neighborhood': Housing and African Americans in Portland, 1941-1945" Oregon Historical Quarterly 158-179. Ethan Johnson and Felicia Williams, "Desegregation and Multiculturalism in the Portland Public Schools" Oregon Historical Quarterly, (Spring 2010), 6-37: Elizabeth McLagan, A Peculiar Paradise: A History of Blacks in Oregon, 1788-1940 (Portland: Georgian Press Company, 1980). City of Portland Planning Bureau, The History of Portland's African American Community (1805 to the Present) (Portland: 1993), 29-32.

38 "Vandals Break Windows in Doctor's Home," The Advocate July 4, 1931.

${ }^{39}$ Mangun, A Force for Change, $277 \mathrm{n} 41$.

${ }^{40}$ Ibid., 154.

${ }^{41}$ Ibid., 277 n41. 
American experience in Portland. ${ }^{42}$ In recognition of his work, Governor Charles A. Sprague nominated Unthank to the Committee of 100 in January $1942 .{ }^{43}$ The Oregonian recognized Unthank as a Black leader who represented Oregon in Philadelphia with 100 other prominent African Americans. Unthank also became chief spokesperson for the Emergency Advisory Council that defended African Americans in Oregon. ${ }^{44}$ Consequently, Dr. Unthank was viewed by both White and Black citizens as a trusted leader in Portland. Moreover, city and state leadership demonstrated their trust in Unthank by nominating him to represent Oregon's Black population.

\section{"The Negro in Portland"45}

"The treatment of the Negro is the greatest barrier to America's moral leadership in the world today." 46

With his knowledge of discrimination in Portland, Dr. Unthank was instrumental in documenting the African American experience. By the time he was in his mid-40s,

42 "Negroes Fight Ban by Unions," The Oregonian December 6, 1941, 10; DeNorval Unthank, "Keeping Fit," The Advocate March 21, 1931, 4.

43 “Man Named By Governor," The Sunday Oregonian, January 18, 1942, 21.

${ }^{44}$ Pearson, "A Menace to the Neighborhood," 164. Dr. Unthank was a well-respected activist in Portland who fought discrimination throughout his life. However, in 1949 he stopped paying dues to the NAACP and Urban League. He almost disappears from the record until he asked by Otto Rutherford to become a member of the executive board of the NAACP in 1952. I am unsure what happened during this time. Possibly his family life took over with several kids at home and in school needing attention, including the marriage of his oldest son. Or, maybe his practice was busy enough to keep him from extra civic duties. I personally believe after fighting for civil rights with three organizations, Dr. Unthank became tired and took several years off from meetings and active participation.

45 "The Negro in Portland," Portland City Club Bulletin, City Club of Portland Archives July 20, 1945, 52 .

${ }^{46}$ Ibid. 
Unthank had gained the trust of the White community with his hard work and ability to bridge racial worlds. In turn, the City Club gained Unthank's trust by reporting on civic issues and trying to create change in Portland. Together the City Club and Dr. Unthank documented racial injustice in Portland in "The Negro in Portland" report.

The City Club formed a committee on race relations October 1944. Dr. Unthank was handpicked because of his medical expertise and involvement in the Black community and his participation was crucial in developing a successful report on the African American experience in Portland. The timing of his nomination in 1943, suggests City Club presidents were looking to integrate. However, the City Club archives lack a definitive source showing which came first, the committee or the report topic. According to Portland historian Darrell Millner, the timing allowed Dr. Unthank to pitch the idea of a study on race in Portland. ${ }^{47}$ On the other hand, the City Club was known for its reports and it seems likely the topics would have come before creating a committee. Whatever the case, Unthank was selected for a committee on race and local African American experience.

The Committee on Race Relations was made up of an eclectic group of White civic-minded individuals. J.C. Plankinton served as chairman. He had graduated from Oregon Agriculture College in 1910 as an electrical engineer and served as president of the Young Men's Christian Association (YMCA) while his wife Elizabeth served as president of the Portland branch of the American Association of University Women. ${ }^{48}$

${ }^{47}$ Darrell Millner, On the Road to Equality: A 50 Year Retrospective (Portland: Urban League of Portland, 1995), 14. 48 "President of YMCA," The Oregonian, November 28, 1928, p. 11. 
Irving Enna was a salesman for Standard Insurance Company who had won the Insurance Man of the Year award and served as president of Portland Life Underwriters. Enna was also executive secretary for the Office Employees Union. ${ }^{49}$ James C. Wallace attended Grant High School before becoming a salesman and later station manager of local news station KOIN. He worked as a publisher for Forest Industries and became vice-president of publications before moving to The Timberman, an international lumber journal, as business manager. Rabbi Irving Hausman arrived in Portland January 31, 1943 before finishing school and being named temple aide for the duration of World War II. ${ }^{50}$ J.R. Wilson owned a market in northeast Portland and later served as vice-president of the YMCA.${ }^{51}$ Howard F. Kessler grew up in Alberta, Canada, before moving to Portland as a journalist for the Oregonian. ${ }^{52} \mathrm{C}$. Girard Davidson was a lawyer from Louisiana who received his law degree from Yale and worked on the Tennessee Valley Authority project before coming to Oregon with the War Production Board. Davidson served as Secretary of the Interior for Henry Truman. ${ }^{53}$ Henry A.D. Smith was a department store executive from Nebraska prior to becoming advertising manager for the department store Lipman Wolfe and Co. Smith also served as president of the Western Galleria Department Store ${ }^{54}$ Reverend Leslie D.V. Dunton grew up in Seaside before taking the post at

49 “Labor's Post War Program for Portland," The Oregonian April 28, 1945.

50 "Ohioan Named Temple Aide," The Oregonian January 29, 1943.

51 "Stuart Ball Elected Head at $88^{\text {th }}$ Annual Y Meeting," The Oregonian February 18, 1956, p. 6.

52 "Howard F. Kessler," The Oregonian January 9, 1968, 1. Kessler later died performing his duties as Broadway Bridge tender.

53 "Interior Post Beckons Two," The Oregonian July 14, 1946, p. 12.

54 “Promotions Manager Smith Wins Promotion," The Oregonian April 5, 1931. 
Calvary Episcopal Church and was an active member of the Lions and Kiwanis clubs. Dr. Unthank was the only African American committee member.

The Committee on Race Relations was tasked with researching the African American experience locally. The committee was especially interested in how the Black experience in Portland compared with others across the nation. Several members sent letters to city officials around the country in an attempt to gain a national perspective on the African American experience. Other members compared education and economic opportunities across the country. Unthank focused on organized labor, medical care, housing, and job discrimination. A research plan was set forth, which included interviewing local citizens who had firsthand experience in education, employment, housing, unions, police harassment, and the medical field. The committee identified experts in the fields and conducted oral interviews to compare with other data. The report was finished and presented to the City Club for approval just short of year later.

The scope of the study focused on racial tensions, discrimination, segregation, and how to eliminate them. The report was published July 20, 1945 with the stated objective "to study the question of race relations," "the treatment of the Negro... and to make recommendations for change... which would relieve immediate and postwar race tensions." 55 It included facets of discrimination and provided examples of systemic and institutional racism persisting in Portland. The committee's intent was to demonstrate

55 “The Negro in Portland," City Club of Portland Archives July 20, 1945, 52. 
"the greatest barrier to America's moral leadership." 56 Furthermore, they assumed the city would act upon their recommendations with bureaucratic changes.

National research demonstrated that most white citizens believed the "Negro problem" was solved. However, the report detailed the poor treatment of Black Americans. ${ }^{57}$ The committee stated, "We are shocked to see that a fair share of the privileges of being an American has not been extended to the Negroes of our land." ${ }^{, 5}$ Using scientific data, the report discredited White racial superiority as a misconception Whites used to justify lower African American social status. Ultimately, the committee blamed poverty and segregation, suggesting equality of opportunity would cure the world of racial prejudice. ${ }^{59}$

The study highlighted the difficultly of being African American by focusing on Southern poverty of Black families. African American poverty led to a lack of education and employment opportunities. "Most Negroes are so desperately poor that it is impossible for them to acquire the education without which they are hopelessly relegated to the unskilled class," leading to less affluence and opportunities, read the report. ${ }^{60}$ In the South, African American children were "compelled by law" to attend inferior schools

\footnotetext{
56 Ibid., 69.

57 Ibid., 52.

${ }^{58}$ Ibid.

${ }^{59}$ Ibid. Isabel Wilkerson suggests the same idea, "Overall, southern migrants represented the most educated segment of the southern black population they left." Wilkerson demonstrates the initial migrants averaged two more years of schooling than those who remained in the south. However, the 1950s would see a decline in that number. Isabel Wilkerson, The Warmth of Other Suns: The Epic Story of America's Great Migration (New York: Vintage Books, 2011), 262.

60 "The Negro in Portland," City Club of Portland Archives July 20, 1945, 53.
} 
that lacked skilled training. ${ }^{61}$ Domestic service was the primary opportunity for Southern Black workers while increased opportunities in factories and railyards existed in the North. ${ }^{62}$

Voting exclusions and segregation practices further demonstrated the plight of Black citizens. African Americans were barred from voting in the South due to exclusions, poll taxes, and property ownership. The majority of southern White businesses, churches and social organizations were racially segregated. The report stated, "Negroes are American by birth, by citizenship and in the social habits - more truly American than millions of white people of recent European origin, yet as a result of circumstances most of them live apart from other Americans." 63 A previously published Urban League study found ten states and twenty-two cities with committees promoting interracial understanding. ${ }^{64}$ The report pushed for police training in race relations in cities such as Detroit, Boston, and Cincinnati. The City Club report optimistically suggested, "If the white population shows a reasonable amount of good will, there are solid grounds for believing that a solution of the Negro-white problem can be reached." ${ }^{\prime 65}$

The local study began with the migration of African Americans to Oregon. The majority of the wartime Black population came from Texas, Arkansas, Oklahoma, Missouri, and Louisiana and made up 53 percent of the total number of migrants to the

61 Ibid., 54.

62 Ibid., 53.

63 Ibid., 54.

64 Ibid.

${ }^{65}$ Ibid., 56. The report had not referred to the antiquated "Negro problem" to this point, nor would it respond further. If it was seen as a derogatory phrase and it was not mentioned in The Observer or any other place of record. 
city. When they arrived to Portland, African Americans were segregated into an area around North Williams Avenue. "This concentration has largely been brought about by an unwritten code of real estate interests governing the sale of property to Negroes only, in a part of this area." ${ }^{\prime 66}$ Segregation in restricted housing led by the Housing Authority of Portland and Portland realtors created dangerous slum areas negatively affecting the Black community through increased vice and crime. Although the majority of Black citizens lived in North Portland, permanently employed African Americans lived in "well-kept individual family dwellings" in other districts segregated from white homes. ${ }^{67}$ Information gathered from a published Urban League report suggested the city's inability to adequately house the number of African Americans coming to Portland was a problem. Reluctance of the Housing Authority of Portland to build permanent or temporary housing for the growing population led Henry Kaiser to build temporary housing for employees in Vanport and Guilds Lake during the war. ${ }^{68}$

Although African Americans found some relief in housing, they were still segregated from Portland labor unions, which excluded Black laborers from membership. Unthank worked to include African Americans in railroad and shipyard unions in the 1930s and into the 1940s. ${ }^{69}$ Discrimination within Portland unions persisted regardless of national anti-discrimination policies passed by Congress. Lack of employment opportunities existed because "Negroes are denied membership in the union and also the

\footnotetext{
66 Ibid., 57.

${ }^{67}$ Ibid.

${ }^{68}$ Pearson, "'A Menace to the Neighborhood," 162-166.

69 "Negro Leader Lauds Ruling," The Oregonian October 8, 1942, p. 12.
} 
right to work within the union's jurisdiction." ${ }^{, 70}$ Discrimination in unions made it difficult for African Americans to find skilled positions or sustain employment.

Employment discrimination also existed within state and federal agencies. Franklin Delano Roosevelt's 1941 Executive Order Number 9346 eliminated discrimination in federal employment on the basis of "race, creed, color, or national origin." ${ }^{, 71}$ At that time, Oregon boasted 10,000 federal employees, of which 132 were African American. Nonetheless, some federal agencies in Oregon reported no Black employees, citing a lack of qualifications among applicants. Multnomah County and the City of Portland had non-discrimination policies similar to those of the federal agencies but lacked Black employees. According to Mildred Fahlen, senior personnel officer of the City Civil Service, the number of African Americans employed by the county and city never rose above fifteen. ${ }^{72}$ Regional director of the Civil Service Commission, Thomas W. Craig, blamed the status of Black employees on the difficulty of changing perceptions of African Americans among White supervisors. As evidence, Craig pointed to the case of a qualified Black applicant with veteran status who was rejected in favor of a White applicant. The committee's report documented a lack of Black employees in city and county positions and argued that agencies needed to follow their existing nondiscrimination policies. ${ }^{73}$

\footnotetext{
70 “The Negro in Portland," City Club of Portland Archives July 20, 1945, 58.

71 Ibid., 59.

${ }^{72}$ Ibid., 60. Multnomah County employed one African American as a janitor who had worked several years. Only 15 African American employees worked for the City as laborers, custodians, and mechanics which employed 2600 workers.

73 Ibid., 59. Craig assured the committee, "the matter was straightened out."
} 
Another area of concern for the committee was discrimination in public accommodations. Hotel managers refused to serve "undesirables regardless of race or color." Restaurant owners reserved the right to refuse service too; some displayed "White Trade Only" signs. Several restaurants served African Americans when Whites accompanied them. Regardless, it was difficult for African Americans to get service in Portland restaurants. "Exceptions are made for Negro celebrities, who are generally accepted as guests," which allowed establishments to claim non-discrimination policies while they still discriminated against most African Americans. Although legislation could change the law, it could not change individual attitudes; and the Black experience of discrimination continued. ${ }^{74}$

Discrimination in the fields of medicine and education had lessened by 1945. Research showed health services were provided to all people regardless of color. However, discrimination existed among patients of low economic status. NAACP president Otto G. Rutherford stated in a letter to the national office, "Discrimination in hospitals is more exemplified by the patients than by the staff," offering a reason why Dr. Unthank made house calls to African American's homes. ${ }^{75}$ An unwritten rule in the Vanport hospital led to segregated rooms where, "Patients are placed where they are happiest. Happiest in this case means segregated." ${ }^{76}$ Black nurses and aides in area hospitals faced less employment discrimination, a direct result of Dr. Unthank's efforts to

\footnotetext{
74 Ibid., 63.

${ }^{75}$ Otto G. Rutherford, "Correspondence between Franklin H. Williams and Otto G. Rutherford," January 22, 1953, Verdell Burdine and Otto G. Rutherford Family Collection 1880s-1980s, Portland State University Special Collections. 76 "The Negro in Portland," City Club of Portland Archives July 20, 1945, 64.
} 
integrate medical staff. The committee reported "there is no evidence of 'color' division, discrimination, or differentiation in either the educational facilities or the educational programs offered by the Portland and Vanport schools." ${ }^{" 77}$ Schools offered students the same opportunities for advancement, and school districts employed nine African American teachers in Portland and Vanport. However, Black teachers had just been hired by the Portland Public School district to start the 1944 school year. Also, schools in North Portland were predominantly Black and segregated from White schools. Although the report suggests that non-discrimination was the rule, White superintendents interviewed by the committee may not fully have understood the complex nature of racial discrimination.

The Portland Police department (PPD) was a major area of concern for the committee. Portland Police Chief H.M. Niles was unenthusiastic about the report and uncooperative. ${ }^{78}$ He stated, "No racial discrimination is practiced by members of the force." However, Black citizens were six times more likely to be arrested than Whites. In an attempt to prove no racial bias, Chief Niles stated, "Negroes were responsible for more crimes" than Whites, which led to more arrests, a sentiment shared by other officers. ${ }^{79}$ Niles justified a lack of African American policemen by claiming they could not pass the Civil Service Exam. The NAACP had worked to integrate the PPD since the 1930s,

\footnotetext{
77 Ibid., 65.

78 Ibid., 68.

79 Ibid., 67.
} 
which intensified with the police killing of innocent African American Ervin Jones in September $1945 .^{80}$

The committee advocated immediate societal change in order to eliminate racial tension. Portland citizens worried that ten thousand African Americans staying in Portland would result in increased unemployment. Discrimination in housing, hotels, employment, restaurants, and hospitals was "unsound, undemocratic, and serves to increase public prejudice," potentially leading to an explosive outcome if it was not rectified. The committee encouraged city officials to collaborate with churches, schools, and hospitals to minimize racial tension. The committee recognized the Urban League, NAACP, Portland Council of Churches, and Council of Social Agencies and commended them for "their efforts to promote interracial understanding and good will." Lastly, the committee stated, "We find that many of the causes of social unrest which lead to interracial strife and violence exist in Portland today. We believe that acute social disturbances and outbreaks are likely in this community unless positive and immediate action is taken to avert such a calamity." 81

Recommendations focused on local and state government. The first recommendation was to form "A statewide committee on Negro-white relations" appointed by the governor, consisting of interracial members. The committee would work with local and state governments to provide training programs to eliminate bias. They

80 "Ervin Jones Inquest Set for October 19" The Observer September 20, 1945, 1. There is no evidence suggesting the City Club and NAACP worked together in forming this report.

81 "The Negro in Portland," City Club of Portland Archives, July 20, 1945, 69. 
would also work with business owners to eliminate racial discrimination and inequalities in the work place as well as in service. Lastly, the committee recommended augmenting police training programs to ease racial tension. ${ }^{82}$

The Oregonian published the conclusions and recommendations in their entirety, calling the report pivotal for racial issues. ${ }^{83}$ Two letters to the editor appearing in the Oregonian and Portland Observer discussed the report. H.R. Emerick of Vanport wrote, "Cannot the Negro understand that fully 80 per cent [sic] of the white people do not care or wish to associate with them? And that is our right and privilege." 84 He continued, "The Portland Inquirer (Negro newspaper) condemns me and also many prominent white people." ${ }^{85}$ His racism was directed at the African American community rather than the City Club. Other than Emerick's, a lack of criticism demonstrated ambivalence or acceptance of the report. A second letter to the Black newspaper, the Portland Observer, called for immediate acceptance of the recommendations by the city. ${ }^{86}$ As with responses in the White press, the lack of Black voices may suggest ambivalence or a lack of knowledge of the report, consequently, it did not generate a lot of activity in the city.

The "Negro in Portland" report highlighted the growing racial tension within the city. It detailed multiple areas of discrimination by shedding light on housing segregation,

82 Ibid.

83 "Racial Study Lauds Groups," The Oregonian, July 20, 1945, p. 9; Millner, On the Road to Equality, 14.

${ }^{84}$ H.R. Emerick, "Negroes and Whites," The Oregonian, July 31, 1945, p. 6.

${ }^{85}$ Ibid.

86 "City Club Accepts Study on Negro in Portland," The Observer, August 17, 1945, p. 4. "The practical application of the democratic principles for which we are fighting requires an immediate vote in favor of the report and recommendations as submitted by the committee." 
discriminatory employment practices, police intolerance, and discrimination in public accommodations. The committee's main purpose was to highlight discriminatory practices in Portland. The report sufficiently detailed discrimination, even including six recommendations to ease the rising tensions. The report was heralded as a success by civil rights activists in Portland. However, within five years the City Club shifted its focus from highlighting discrimination to tackling the problems causing racial tension.

\section{"Total Exclusion"87}

"Prejudice against people on account of color, religion and national origin does exist in Portland. Intense prejudice is found in only a small minority, and mild prejudice is fairly common. " 88

Five years after the City Club report was published, Portland city officials began to study the cause of growing racial tensions. Dorothy McCullough Lee began investigating racial discrimination in her first month as Mayor. ${ }^{89}$ Lee appointed a Committee on Inter-group Relations in January 1949 and tasked it with finding a solution for growing racial tensions. City Club Board of Governors member and Urban League president David Robinson accepted an invitation to be on the committee. A public hearing was held with civic organizations providing suggestions for a solution which the

${ }^{87}$ Walter B. Moore, “Civil Rights," Portland City Club Bulletin, 31, no. 20. City Club of Portland Archives, September 22, 1950, p. 70.

88 Ibid.

${ }^{89}$ Ibid. Dorothy McCullough Lee alienated herself from the community by proposing the civil rights bill. Although a variety of factors contributed to her one term, the Civil Rights Ordinance was a major proponent. See: Meryl Lipman, "Dorothy McCullough Lee (1902-1981)" The Oregon Encyclopedia, 2016, http://oregonencyclopedia.org/articles/lee_dorothy_mccullough_1902_1981_/\#.V1BKdZ $\underline{\mathrm{XmrX} 4}$ accessed April 13, 2016. 
committee researched and a conclusion was made. In January 1950, the committee met with Mayor Lee and proposed a civil rights ordinance, which amended the police code to prohibit city businesses from discriminating against people based on race, color, ethnicity, or religion..$^{90}$ The Portland City Council passed a referendum on February 21, 1950 , and sent the measure to voters on the November ballot. ${ }^{91}$

The City Club responded by creating a committee to research the proposal and its effects. Urban League Executive Secretary Edwin Berry stated, “This report will carry a great deal of significance since the community looks to the City Club for guidance in such matters." 92 The committee consisted of Edwin J. Dryer, Harris Dusenberry, Erling Hustvedt, John A Leiter, Stewart H. Tremaine, and Walter B. Moore. The committee interviewed Urban League Executive Secretary and NAACP member Edwin Berry, as well as the chairman of the United Committee for Civil Rights and various hotel and restaurant employees, providing committee members with a broad subset directly affected by the ordinance. ${ }^{93}$

City Club research focused on local discriminatory practices across the U.S. Discrimination in hotels and restaurants denied access to African Americans. A third of Portland restaurants did not serve Black patrons but claimed they did not discriminate. Total exclusion at hotels, dance halls, restaurants, bowling alleys, and skating rinks was common and reflective of discrimination nationally. ${ }^{94}$ Yet discriminatory practices were

\footnotetext{
90 Ibid., 69.

91 Ibid., 70.

92 “MSSULP 1949 Meeting Minutes," OSU Archives, 39.

${ }^{93}$ Moore, Portland City Club Bulletin, 70.

${ }^{94}$ Ibid.
} 
challenged during this period. Six years earlier, California's legislature passed a bill eliminating discrimination in public accommodations while Denver removed legal segregation in theaters. ${ }^{95}$ Like Portland, Spokane continued to fight discrimination in public accommodations into the 1950s as President Harry S. Truman's administration fought civil rights on the national level through executive orders. ${ }^{96}$

The City Club committee presented arguments for and against the ordinance, although it advocated its passage. According to the report, voting for the ordinance meant improving minority rights because "Discrimination...is in opposition to the principals [sic] of the Declaration of Independence." The committee believed "Passage would be of benefit to the United States Foreign Relations." "We are engaged in actual warfare," the report stated, "our opponents are attempting with some success to discredit the sincerity of our ideals by pointing out specific inconsistencies in our practices at home." Lastly, the committee reported that the ordinance would improve local race relations as research demonstrated decreased racial friction in cities with similar civil rights laws. ${ }^{97}$ Opponents suggested it was too invasive.

Opponents argued that regulating private business was illegal, although research revealed it was legal in the eighteen states with similar laws. Opponents favored a state law to a city ordinance while the committee cited economic improvement in cities with similar ordinances. Opposition hinged on the loss of revenue in restaurants and hotels

${ }^{95}$ Matthew Whitaker, Race Work: The Rise of Civil Rights in the Urban West (Lincoln: University of Nebraska Press, 2005), 82.

${ }^{96}$ Dwayne A. Mack, Black Spokane: The Civil Rights Struggle in the Inland Northwest (Norman: University of Oklahoma Press, 2014), 84.

${ }^{97}$ Moore, Portland City Club Bulletin, 71. 
affected by the ordinance. Opponents argued the new ordinance would discriminate against White citizens stating, "The law would discriminate against white people. If this were to happen to the members of a minority group, it is argued that they would have recourse to the law, whereas a white person would not." The City Club committee, however, believed white discrimination would not happen especially if the business "was actually and continuously observing the law.” Lastly, opponents argued African Americans had access to their own accommodations. According to the report, "this argument admits the existence of discrimination, and the question remains whether discrimination is to be tolerated or not." 98

City Club members were encouraged to support the ordinance on the November ballot. The report read, "Your committee feels there is considerable discrimination in Portland and that positive steps should be taken against it. Passage of this ordinance would help promote the rights guaranteed under the Bill of Rights." 99 The committee recommended a list of businesses covered by the law due to its broad wording and a state law that would benefit all Oregonians. Opposition to the ordinance existed among a few City Club members. However, they were in the minority and most were hotel owners and managers. The City Club Board of Governors approved the report and issued recommendations on September 18, 1950. The general membership approved on September 22. ${ }^{100}$

\footnotetext{
98 Ibid., 72.

${ }^{99}$ Ibid.

${ }^{100}$ Ibid., 73. "David Robinson abstained from voting because of his membership in the Inter-group Relations Committee.”
} 
After recommending the Civil Rights Ordinance, City Club members believed passage was soon to follow. Portland architect and City Club member Robert Fritsch stated, "Most major social reform has been implemented by law, you can't count on good intentions." 101 The City Club joined with other organizations to pay for advertising in support of the ordinance. ${ }^{102}$ On November 8 , however, voters struck down the ordinance by $55 \%$, resulting in a loss for civil rights. City Club members had overestimated their reach with Portland's lower class citizens as the Oregonian reported the measure failed to pass among lower class whites. Without any mention of the loss, the City Club continued organizing committees and researching important city issues.

The two City Club reports demonstrated important organizing strategies employed by small cities in the West as they addressed their own racial climates in the war and postwar period. Portland's Civil Rights movement provides examples of successful campaigns in cities that lacked significant African American populations. In these cities, Civil Rights organizations like the NAACP and the Urban League participated with White organizations and leaders to promote equality. The City Club indicates the cross-cultural interaction necessary to tackle issues of race in the city. The City Club reports provide examples of White middle class business owners grappling with issues of inequality in order to strengthen the whole community. The reports expanded the audience for previously published research by the NAACP and Urban League. In the case of Portland, City Club members sought diversity by including Dr.

101 "Civil Rights Law Indorsed: City Club Members Uphold Committee," The Oregonian, November 9, 1950, p. 7. 102 "Line up on the Right Side," The Oregonian, November 6, 1950, p. 28. 
Unthank, who acted as a bridge between White and Black Portland. In the next chapter, we will continue to follow Unthank as he worked to establish a chapter of the Urban League in Portland. 


\section{Chapter Three}

\section{"The Highest Degree of Cooperation"1}

"More than 100 of the most responsible civic, religious, labor, political and fraternal organizations supported the ordinance."

The Urban League of Portland hosted University of Washington anthropologist

Dr. Melville Jacobs in November 1945. A capacity crowd of 450 packed the central library to listen to him speak on the myth of white supremacy. Jacobs asserted that science did not support that one group or race was innately better than another. ${ }^{3} \mathrm{He}$ recommended the entire community follow the Urban League mission of interracial cooperation, explaining that the role of the league was to inform the Pacific Northwest about race relations. He commended the local organization "for its varied makeup and its growth in six months to a body of 600 members of all races and creeds.." ${ }^{\text {D }}$. Jacobs reached 1750 individuals, including fifty teachers at presentations at Grant High School and Washington High School. ${ }^{5}$ Jacobs had made the case for interracial cooperation and intergroup collaboration. The Urban League brought together civic activists from other groups to create strategies for attaining equality. Jacob's recommendation proved fruitful with the passage of the accommodations act in 1953.

\footnotetext{
${ }^{1}$ Edwin C. Berry, "Why the Civil Rights Ordinance Did Not Pass," Verdell Burdine and Otto G. Rutherford Family Collection 1880s-1980s, Portland State University Special Collection, p. 1.

${ }^{2}$ Ibid.

3 “Races Equal, Savant Holds: Opportunity Lack Seen as Problem," The Oregonian November 29, 1945, p. 7.

${ }_{5}^{4}$ Ibid.

5 “MSSULP 1945 Meeting Minutes," Oregon Multicultural Archives Oregon State University Libraries, Special Collections and Archives Research Center, 29.
} 
This chapter details the strategies used to further civil rights in Portland leading up to the passage of the state's accommodations bill. The NAACP and City Club of Portland had worked to fight discrimination and inform the public of racial tension. However, it was necessary to create a unifying organization that focused on local strategies. The Urban League of Portland became that organization by forming a think tank of Portland's civic activists. This chapter provides a look at the strategies the Urban League, collaborating with other organizations, used to create change in Portland. The passage of a statewide bill would not have been possible without the Urban League's leadership and activism.

In the beginning, the National Urban League originally fought discrimination as the Committee on Urban Conditions Among Negroes. ${ }^{6}$ The Urban League was instrumental in furthering the aims of African Americans throughout the United States, most significantly in bringing middle-class Black and White men together during the postwar period and furthering the needs of Black professionals. One main focus of the national organization was African Americans employment. The League urged young Black men and women to attend college. After World War II, the organization persuaded Fortune 500 companies to support career training at Black colleges, as well as placing African Americans in "upper-echelon jobs."7 The organization continued its rise to prominence through the classical phase of the Civil Rights Movement by fighting employment discrimination through interracial cooperation. The Urban League of

6 “Mission and History," National Urban League, accessed May 27, 2015. http://nul.iamempowered.com/who-we-are/mission-and-history.

${ }^{7}$ Ibid. 
Portland, founded in 1944, brought middle-class Blacks and Whites together in a multiracial organization. Interracial cooperation contributed to create effective strategies in civil rights legislation.

The National Urban League office determined West Coast support by holding meetings during the 1930s. Leaders made trips from Seattle to Los Angeles, stopping in Portland to speak on national racial discrimination at presentations that were usually well attended. ${ }^{8}$ Meetings continued into the 1940 s with Black participation growing steadily. Most events were held at the First African Methodist Episcopal (AME) church on North Williams Avenue in North Portland. ${ }^{9}$

In 1944, the Field Secretary for the National Urban League, Reginald Johnson, arrived to investigate the "hostile racial environment" of Portland. ${ }^{10}$ Johnson made at least two trips to Portland in 1944, the first in February to conduct "a survey of conditions among the Negroes of coastal war production communities." ${ }^{11}$ The second was in October when he spoke in Vanport on "Minority Groups and Their Relationships

8 "City News in Brief: Seattle League Leader Here," The Morning Oregonian, February 19, 1931, p. 9.

${ }^{9}$ The use of the Black church within the Civil Rights Movement is well documented and the Portland movement was no different. For additional information see: Clarence Taylor, "African American Religious Leadership and the Civil Rights Movement," The Gilder Lehrman Institute of American History, 2016, accessed June 7, 2016, http://www.gilderlehrman.org/history-by-era/civil-rights-movement/essays/africanamerican-religious-leadership-and-civil-rights-m. David Everett Swift, Black Prophets of Justice: Activist Clergy before the Civil War (Baton Rouge: Louisiana State University Press, 1989). Clarence Taylor, Black Religious Intellectuals: The Fight for Equality from Jim Crow to the Twenty-First Century (New York: Routledge, 2002).

${ }^{10}$ Darrell Millner, On the Road to Equality: The Urban League 1945-1995 (Portland: The Urban League of Portland, 1995), 12.

11 "Negro Work Problems Seen For Portland, Vancouver," The Oregonian February 13, 1944, p. 10. "Girl Reserves Plan Meetings," The Oregonian, February 15, 1944, p. 8. 
in a Democratic Society," as well as to the NAACP on "The Negro on the West Coast."12 Johnson concluded his visits by asserting that discrimination caused Black unemployment, inadequate housing, negative stereotyping, redlining, police harassment, and race-related strain. ${ }^{13}$ He encouraged citizens to organize a local branch of the Urban League to attend to racial conflicts and rising tensions. ${ }^{14}$

"Negro Social Aim Furthered" read a June 12, 1944, Oregonian headline. The article detailed the formation of a local Urban League branch with Harry W. Bruck, a White campaign manager for the Council of Churches, as president. The Urban League followed the national model of African American self-reliance, adapting to the community's needs in tackling problems in housing, employment, recreation, and health discrimination growing in Portland. ${ }^{15}$ In November the Oregonian announced, "Portland now has an Urban League... under the leadership of Reginald A. Johnson,” as the national figurehead. ${ }^{16}$

Formed by an interracial membership, the Urban League was a think tank of Portland activists. The first official meeting of the board of directors took place on

12 “City News in Brief: Minority Groups," The Oregonian, October 12, 1944, p. 11. "Group Plans Meeting," The Oregonian, October 13, 1944, p. 9. "Group Plans Luncheon," The Oregonian, October 25, 1944, p. 9.

${ }^{13}$ Millner, On the Road to Equality, 12.

${ }^{14}$ Millner, On the Road to Equality, 12. There is some confusion or lack of clarity as to when the branch was founded. According to Dr. Darrell Millner, the branch was officially created April 1945, with Edwin C. Berry as President. However, according to meeting minutes housed at the Oregon State University Special Collections and Archive Center, the Portland branch of the Urban League was created soon after Johnson departed in June 1944.

15 "Negro Social Aim Furthered," The Oregonian June 12, 1944, p. 9.

16 "Portland Negroes Set Up Local Urban League Unit," The Oregonian November 25, 1944, p. 7. 
January 25, 1945. It included White Vanport School superintendent James T. Hamilton as Chairman. Harry W. Bruck was chairman of the board of trustees at Lewis and Clark College, as well as a member of the Portland Realty Board ${ }^{17}$ Ernest Boyd (E.B.) MacNaughton was the White president of the First National Bank of Oregon, president of the Oregonian publishing company, and President of Reed College while a member of the Urban League. ${ }^{18}$ Father Lee Owen (L.O.) Stone was a White activist and the first vicar of St. Philip the Deacon Episcopal Church and a board member of the NAACP. ${ }^{19}$ Julia Smith was a Black NAACP member with a Bachelors of Arts degree in Sociology from Linfield College. ${ }^{20}$ Harry A. D. Smith, a White civic leader, was the Olds, Wortman \& King retail store vice-president, as well as a member of the City Club's committee on race relations. ${ }^{21}$ African American Alta Smith Corbett was a graduate of Smith College in Massachusetts, trustee of the Unitarian Church, and president of the Portland League of Women Voters from 1938 to $1940 .{ }^{22}$ Reverend Jesse James (J.J.) Clow was minister of

17 “Harry W. Bruck," FindAGrave.com September 29, 2012, http://www.findagrave.com/cgi-bin/fg.cgi?page=gr\&GRid=97980315. Accessed April $18,2016$.

${ }^{18}$ E. Kimbark MacColl, The Growth of a City: Power and Politics in Portland, Oregon 1915 to 1950 (Portland: The Georgian Press, 1979), 207-211, 390; "E.B. MacNaughton," Presidents of Reed, Reed College Archives.

19 "Father Lee Owen Stone," Oregon Multicultural Archives Blog, April 17, 2012, accessed April 18, 2016, http://wpmu.library.oregonstate.edu/oregon-multiculturalarchives/2012/04/27/father-lee-owen-stone/.

20 “Julia Smith 1915-2010," Inside Bay Area Obituaries April 11, 2010, accessed April 18, 2016, http://www.legacy.com/obituaries/insidebayarea/obituary.aspx?n=juliasmith\&pid=141676805.

21 "Olds Manager Named Officer," The Oregonian, April 27, 1945, p. 23; "Racial Study Lauds Groups: City Club Survey Urges Civic Action,” The Oregonian, July 20, 1945, p. 9.

22 “Alta Smith Corbett," The Oregonian, September 10, 1976 p. 50. 
Portland's first African American Baptist church, Mt. Olivet, and former president of the local NAACP. ${ }^{23}$ Emma Chiles Walker was one of the first African American teachers in the Portland Public School district. ${ }^{24}$ Dr. Unthank was the second African American doctor in Portland, a member of the City Club, and former president of the NAACP. ${ }^{25}$

The inaugural meeting focused on finding a national leader to act as executive secretary and spokesman of the Portland branch. Members hoped that African American leader, Dr. Ralphael O'Hare Lanier, the president of the Division of Negro Affairs in the National Youth Administration, would direct the local branch. ${ }^{26}$ Alta Corbett had met with Lanier in New York City and said, "[Lanier] is very much interested in being connected with an organization with a constructive approach rather than with a protest organization," signaling the kind of organization local activists hoped to create. ${ }^{27}$

A brief discussion of a civil rights bill circulating in the statehouse during the legislative session concluded the meeting. The senate judiciary committee proposed a state civil rights bill in 1945. The bill focused on assisting Japanese Americans in returning to their former status after being imprisoned in internment camps following

${ }^{23}$ Rudy Pearson, “Clow, J.J. (1893-1979),” BlackPast.org, 2015, accessed April 18, 2016, http://www.blackpast.org/aaw/clow-j-j-1893-1979.

${ }^{24}$ Darrell Millner and Carl Abbott, Cornerstones of Community: Buildings of Portland's African American History (Portland: Bosco-Milligan Foundation Architectural Heritage Center, 1997), 194. Janet Eastman, "Change: Humboldt Neighborhood's History, Future: Sleeping in Portland," The Oregonian, January 1, 2015, accessed April 18, 2016, http://www.oregonlive.com/hg/index.ssf/2015/01/north_portlands_humboldt_neigh.html. 25 "MSSULP 1945 Meeting Minutes," Oregon Multicultural Archives, 1. Considered the first African American physician in Portland, Dr. Unthank is actually the second after J.A. Merriman.

${ }^{26}$ Peggy Hardman, "Lanier, Ralphael O'hara," Handbook of Texas Online, accessed April 18, 2016, http://www.tshaonline.org/handbook/online/articles/fla88.

27 “MSSULP 1945 Meeting Minutes," Oregon Multicultural Archives, 1. 
World War II. ${ }^{28}$ Corbett asked the other officers whether the Urban League should support the bill. Reverend Clow asserted the NAACP believed the bill had "no teeth" but thought it was better to have a weak bill than no bill at all. ${ }^{29}$ Urban League members did not take a vote and ended the meeting without consensus. Unfortunately, the legislature voted down the Civil Rights Bill in a 24 to 6 decision on the grounds that civil rights for Asian Americans meant increased rights for African Americans which they were not ready allow. ${ }^{30}$ It would be five years before the League would have another chance to support a similar bill, but by then they would be better equipped to argue for its passage.

The newly formed group reached out to Lanier by letter. He responded with questions regarding the position. ${ }^{31}$ But by February 1945, Lanier was no longer a candidate for the position of director, having accepted a position in the Bureau of Services of the United Nations Relief and Rehabilitation Administration, which resulted in him becoming the U.N. minister to Liberia. ${ }^{32}$ With urgency the board began a search for someone with national significance to head the local branch. The chairman contacted

28 "Civil Rights Bill To Be Debated," The Oregonian, January 24, 1945, p. 9. Manya Bender, "Unity Urgent," The Oregonian, February 18, 1945, p. 17. 29 "MSSULP 1945 Meeting Minutes," Oregon Multicultural Archives, 2.

${ }^{30}$ Bender, "Unity Urgent," The Oregonian, 17. California and Washington state both included Japanese Americans and African Americans in their respective public accommodations laws.

${ }^{31}$ The January meeting seems busy for a first encounter of the board of directors. Perhaps the group had gathered before and made plans for future meetings. Furthermore, the discussion suggests the board met previously to secure a national figurehead presiding over the local branch. Although it looks as though there were previous meetings, the only sources confirming such existed are newspaper accounts of the organization asking for admittance to the Community Chest. Therefore, it would be erroneous to imply such meetings took place.

${ }^{32}$ Hardman, "Lanier, Ralphael O'hara," Handbook of Texas Online. 
the national office to secure a candidate as soon as possible: "time is [of] the essence...the Board wants the national office to make this appointment forthwith." ${ }^{33}$ It was not long before they were able to secure a seasoned activist for the local branch.

Edwin C. "Bill" Berry was the African American leader with national prominence the Urban League needed to jumpstart their mission. Berry, one of five children, grew up in Oberlin, Ohio. His father was an attorney and his mother was a homemaker. Berry was six when his father died and his mother took over sole responsibility of running the home, working as seamstress, cook, and boarder. Berry attended Oberlin College but moved to Pittsburgh in 1935, graduating from Duquesne University with a degree in education. He then began his thirty year career with the Urban League as Group Work Secretary for the Pittsburgh branch in $1938 .{ }^{34}$ For seven years, Berry worked on housing and employment discrimination, where he caught the eye of the national office. His experience in Pittsburgh made him a strong leader for Portland's budding Urban League branch.

On Friday, April 20, 1945, the board announced the thirty-five year old Berry would arrive the following Tuesday. The group presented Berry with a list of accomplishments it had achieved prior to his arrival. ${ }^{35}$ Berry addressed the board of directors six days later and expressed eagerness to begin working on the issues specific to Portland. His enthusiasm was infectious as board members immediately expressed their

33 "MSSULP 1945 Meeting Minutes," Oregon Multicultural Archives, 3. ${ }^{34}$ Holly Roose, "Edwin C. 'Bill' Berry (1910-1987), BlackPast.org: Remembered \& Reclaimed, 2015, accessed March 21, 2016, http://www.blackpast.org/aah/berry-edwinc-bill-1910-1987.

${ }^{35}$ Moreover, it proves the Portland Branch was working as a local entity without the need of a national figurehead. Branch leaders worked well together with few problems, at least according to the minutes. 
desire to get started as well. Board members discussed collaborating with the Y.M.C.A, which Berry dismissed, telling the group it was too early to collaborate with other agencies. Instead, he said, it was time to build a local Urban League identity. ${ }^{36}$ Change within the organization fluxed in the early months of the organization. In May the board met to discuss the resignation of Chairman Bruck and President James Hamilton, both White members. Hamilton's employment required him out of the city for much of the year and he worried other board members were inconvenienced. MacNaughton recommended the board elect William L. Brewster Jr., a White leader from a well-respected and longtime family of Portland, to replace Hamilton. ${ }^{37}$ Brewster was dean of admissions at Reed College, as well as on the board of directors for the Oregon Mental Hygiene Society, Library Association of Portland, and Board of Community Chest. To demonstrate how interested he was in working with the Urban League, Brewster offered to resign from the Community Chest Budget Committee. Board members elected Brewster in June as the second president of the newly formed group. ${ }^{38}$

The board of directors lauded the election of Brewster to the League's presidency as the arrival of the Urban League. The Oregonian reported on June 27, "With the election of William L. Brewster Jr. as president and the arrival of Edwin C. Berry, the Urban League of Portland is ready to launch a program of co-operative interracial planning and counseling to solve some of the problems of the thousands of Negroes who

\footnotetext{
36 “MSSULP 1945 Meeting Minutes," Oregon Multicultural Archives, 6.

${ }^{37}$ Ibid., 8.

38 Ibid.
} 
are now residents of the city." 39 According to Berry the city was "bewildered" by the increased Black population but the Urban League would solve some of the tension accompanying the growth. ${ }^{40}$ In his view, the Urban League would integrate African Americans into mainstream society, improving their lives and promoting interracial sensitivity to eliminate racial tensions and discrimination. ${ }^{41}$

By June the Urban League was moving quickly. The organization formed an executive committee that oversaw subcommittees researching industrial relations, housing, and public relations. Board members with knowledge on the subjects chaired each subcommittee. ${ }^{42}$ For example, the Industrial Relations Committee investigated racial problems involving employment. It was also charged with finding or creating new job opportunities for Portland African Americans. The responsibility of the Housing Committee was to investigate and report on housing problems, specifically overcrowding, poor conditions, and the lack of housing. The Public Relations Committee collected evidence to refute Black stereotypes and folklore, then shared their material with the public. All subcommittees were entrusted to dispel myths and stereotypes of African Americans by providing "authentic material."43

In addition, the board was concerned with extending its work across the Columbia River to Vancouver, Washington, where there was no chapter. Unthank, Berry, and Smith

\footnotetext{
39 "Race Planning Soon To Start: Urban League Set To Aid Negroes," The Oregonian, June 27, 1945, p. 9.

${ }^{40}$ Ibid.

41 The Urban League of Portland, "Notice! Purpose and Scope," The Observer, May 31, 1945, p. 4. "MSSULP 1945 Meeting Minutes," Oregon Multicultural Archives, 15.

42 Ibid., 10.

43 Ibid., 11.
} 
spoke with Ralph Reed from the Vancouver Community Chest to get funding for the Portland organization. Reed wanted to see how beneficial the Urban League could be to African Americans in the Vancouver area, stating, "Vancouver and Portland are directly interrelated, and matters which affect Vancouver will also affect Portland, and viceversa." 44 The two cities were connected with citizens working across the river in both directions. However, the Black communities were more entrenched as most African American employment was located in the rail and ship yards. Berry believed it was imperative for the Urban League to work with both cities and, therefore, gain compensation from the Vancouver Community Chest. Reed, however, recommended the Urban League offer services before it requested any funds. For the time, league members backed away from requesting funds, believing Vancouver African Americans would be impacted by Urban League efforts. Several years later the Urban League began receiving funds from the Vancouver Community Chest.

The Urban League created an interracial organization in hopes of easing racial strife in Portland. Under Berry's direction the Urban League focused on unemployment, housing, and public relations. In the coming years league membership would create strategies to combat discrimination in the workplace, housing market, and public perception.

44 Ibid., 12. 


\section{"Postwar Outlook"45}

"One of the widespread consequences of this war is the growing determination among colonial, subject and minority peoples everywhere to win for themselves a share of the freedom for which the allied nations are fighting." 46

In June 1945, the Oregonian ran a series titled "Negroes in Portland: What Is

Their Postwar Outlook?" The report cited White journalist and former presidential nominee Wendell L. Willkie's study of African Americans and the racial problem. Willkie had recently written an article for Collier's Magazine calling for "the equitable treatment of racial minorities in America" and the Oregonian used it as a basis for a local review of racial discrimination. ${ }^{47}$ White Oregonian writer Ron Moxness questioned Portland business owners regarding African American employment after World War II and reported the outlook was grim. Many business owners asserted there would be no jobs for people of color when the shipyards closed. Urban League official and local businessman E.B. MacNaughton feared "racial disharmony" would characterize Portland's future if African Americans stayed while war production jobs ceased. ${ }^{48}$ However, MacNaughton told Moxness that wishing the Black population would leave was no solution. He offered, "Neither is a solution going to be found in shoving the Negroes here into black ghettos or slum areas or trying to keep them in industrial

${ }^{45}$ Ron Moxness, "Negroes in Portland: What Is Their Postwar Outlook?" The Oregonian June 17, 1945, p. 54.

${ }^{46}$ Ibid.

${ }^{47}$ Anne O'Hare McCormick, "Wendell L. Willkie Rush County," IHB Marker Text Review, accessed March 21, 2016, www.in.gov/history/files/70.1969.1Willkiereview.pdf.

${ }^{48}$ Ron Moxness, "Negroes in Portland: What Is Their Postwar Outlook?" The Oregonian, June 17, 1945, p. 54. 
serfdom." ${ }^{49}$ For his part, Moxness was adamant the employment problem needed to be solved, calling it "an issue of vital importance," concluding, "the deep patience of the colored people is nearing its end." ${ }^{, 50}$

The following week the Oregonian published an article focused on the differences between Portland and Seattle's racial problem. The solution to Seattle's racial problem was the creation of a civic unity committee by Mayor William F. Devin. The group successfully changed the minds of many citizens who previously believed there was no problem. In contrast, Portland Mayor Earl Riley did not believe there was a racial problem and, therefore, did not organize a similar committee. Moxness inferred the Urban League was similar to Seattle's unity committee: “A branch of the National Urban League has been set up in Portland, with an interracial membership of well-known citizens interested in community engineering." ${ }^{51}$ The organizations interracial makeup seemed to be significant when discussing the easing of racial stress.

A major focus of the second article was discriminatory practices in restaurants and hotels. Portland was no different than the rest of the West when it came to public accommodations, where African Americans were barred from White establishments after the Civil War. Many Black residents held jobs in the service industry prior to 1900, but as more white males joined service industry unions, Black males were pushed out, eventually leading to few African Americans working in the industry. ${ }^{52} \mathrm{Jim}$ Crow

\footnotetext{
49 Ibid.

50 Ibid.

${ }^{51}$ Ron Moxness, "Negroes in Portland: What Is Their Postwar Outlook?" The Oregonian, June 24, 1945, p. 49.

52 Taylor, In Search of the Racial Frontier, 198-199.
} 
practices followed southern Whites during WWII to the West and people of color were restricted from dining in restaurants or staying in hotels run by white owners. ${ }^{53}$

According to DeNorval Unthank, African Americans were unhappy with signs that read "white trade only." Although Unthank voiced his concerns, the state legislature defeated a bill in 1945 which would have made it a misdemeanor to discriminate against people due to race or ethnicity in restaurants and hotels. Much like other states that adopted earlier legislation, the bill would have created a model for building tolerance within the state of Oregon. ${ }^{54}$

The Urban League held an interracial reception for Berry and his wife at the St. Philip's Parish House in an affluent White neighborhood as a recruitment tool. The reception was attended by 500 people. Although the reception was an introduction to the Berrys, it also formally introduced the Urban League and its leadership. ${ }^{55}$ The reception offered the Urban League a chance to gain new members from the affluent Ladd neighborhood. Information of the 52 people who joined at the reception are not provided. However, if new membership was representative of the organization's leadership, there were more White than Black members. Berry urged a need for more members regardless of race and asked the leadership to secure new members to build the league's reputation and further its goals of bettering the African American experience in Portland. National Urban League Executive Secretary Lester Granger also urged the new chapter to obtain

\footnotetext{
${ }^{53}$ Whitaker, Race Work, 94; Mack, Black Spokane, 37.

${ }^{54}$ Moxness, "Negroes In Portland," 49.

55 "MSSULP 1945 Meeting Minutes," Oregon Multicultural Archives, 17; "Race Planning Soon to Start," The Oregonian, 9.
} 
"as many members as possible." 56 The Urban League was an integrated organization from its inception and would stay that way through the $1950 \mathrm{~s} .{ }^{57}$

It had taken the Urban League almost a year to get a national figurehead and create committees focused on employment, housing, and public relations. The organization now needed to begin working on the problems of racial discord. Berry's enthusiasm would prove essential as Portland's Black community kept him busy. He saw unemployment as a contributing factor of racial tension and began his focus there.

\section{"Hold Your Job"58}

"In order to make Negro workers realize how important it is to give a topnotch performance on every job they now hold." 59

Berry worried about postwar African American unemployment, which looked bleak due to employment discrimination. Berry suggested the Urban League acquire an Industrial Secretary to secure full-time employment for African Americans by working with applicants, employers, and union officials to send qualified applicants to interviews. An Industrial Secretary could research employment opportunities, interview applicants, assess work habits and qualifications, as well as interview employers and labor leaders, and, therefore, dispel racial stereotypes that prevented employers from hiring African

\footnotetext{
56 “MSSULP 1945 Meeting Minutes," Oregon Multicultural Archives, 18.

${ }^{57}$ Millner, On the Road to Equality, 12.

58 “MSSULP 1945 Meeting Minutes," Oregon Multicultural Archives, 21.

${ }^{59}$ Ibid.
} 
Americans. It would be the secretary's job to match qualified applicants with employment from which African Americans had been previously excluded. ${ }^{60}$

Berry worked aggressively to secure employment for African Americans as he persuaded businesses and unions to accept Black workers. He held conferences with the Bell Telephone and Kaiser personnel managers, as well as the War Manpower Commission executives. At the meeting with Kaiser, the Swan Island superintendent announced he would stop recruiting Black women because he believed they did not work as hard as Black men. Berry worried this was part of a broader shift to displace African American workers altogether. The foundation for his worry was a survey the shipyard had produced comparing the performance of Black women to Black men. He believed the report included false information. Concerned this report would be made public, Berry explained, "It does show that employers are already planning to displace Negro workers as soon as cutbacks begin...to 'prove' that Negroes are not good workers." 61 Berry recommended a "Hold Your Job" campaign focused on Black workers. They would give a "top-notch" effort in order to impress employers. He believed if African American laborers worked harder they would demonstrate their importance to employers. ${ }^{62}$ Unfortunately, Berry did not get the Hold Your Job campaign started before shipyards began to lay off workers.

A revelation from September 1945 came from a meeting of the United States Employment Service (USES) with which Berry was building a relationship. He discussed

\footnotetext{
${ }^{60}$ Ibid., 19.

${ }^{61}$ Ibid., 20-21.

62 Ibid., 21.
} 
the topic of Black employment with the director of the employment service, Mr. Bagan, who expressed interest in changing the way the organization assisted Black workers. Bagan indicated that, unless an employer specifically asked for an African American laborer, USES assumed the employer did not want a Black employee. Bagan suggested Berry consult with USES employees on African American employment because Black laborers were not being offered fair employment due to their hiring practices. ${ }^{63}$ Berry believed if he could find a way to change a company's culture on race, he could find better employment opportunities for African American workers.

League members attempted to work with other civic organizations on employment practices in an effort to create opportunities for African Americans. Dr. Unthank met with White Catholic priest, Father Thomas Tobin, and his Committee for Interracial Principles and Practices hoping to find a way for the committees to cooperate and reduce overlap of efforts. However, according to Unthank, "Members of Father Tobin's committee were defensive and resisted committing themselves to cooperation." It was important for organizations to cooperate to find solutions to the unemployment problem. However, the Urban League wanted to be the organization fighting for employment rights in Portland, and cooperation with Tobin's committee could mean giving up some control. Urban League Executive Secretary Lester B. Granger told Portland branch officials, "It is impossible to carry on a total Urban League program without agitating some adverse feeling in the community." 65 A year earlier George

\footnotetext{
63 Ibid., 23.

${ }^{64}$ Ibid., 23.

${ }^{65}$ Ibid., 24.
} 
Streator, labor representative from Washington, D.C., urged cooperation for better civil rights strategies in Portland. "One of the worst problems here has been created by Negroes jockeying for leadership among themselves," he complained. "No one person should wear the feathers. ${ }^{" 66}$ A year later, organizations were still fighting over who controlled aspects of the Civil Rights movement rather than finding solutions.

A lack of cooperation continued as organizations fought to keep their footholds. In November 1945, Berry reported Black women were increasingly resistant to domestic service and suggested the Urban League create a standard for employment, including working conditions, minimum wage, working hours, vacation, and sick pay. ${ }^{67}$ Alta Smith explained the YWCA and USES were already studying the problem and suggested working together. However, Berry suggested the League create a set of standards and then present them to the YWCA. This motion was seconded and passed. ${ }^{68}$ Once again, an organization would bear the cross of an already established club while agitating other organizations.

William Brewster and Edwin Berry organized a meeting of business owners to discuss their experiences with Black workers in September, 1945. Lester B. Granger, Urban League Executive Secretary and social and educational director from New York, spoke to over 400 attendees. ${ }^{69}$ Brewster was encouraged by the discussion, which took place after Granger's talk. Business owners and union officials offered honest and

\footnotetext{
66 "Racial Issues Cause Dissent," The Oregonian, August 11, 1944, p. 9. 67 “MSSULP 1945 Meeting Minutes," Oregon Multicultural Archives, 28. ${ }^{68}$ Ibid.

69 "Most Negroes Seen Staying," The Oregonian, September 20, 1945, p. 7.
} 
intelligent comments on their experience with Black workers. Although some business owners described difficulties when using African Americans, others reported "encouraging accounts of their experiences with Negro workers.",70

By the end of 1945, Berry believed the Urban League focus was better suited toward employment practices and board members agreed. Berry suggested African Americans working in positions visible to the public would increase the public consciousness of Black Americans. He also proposed that visible employment would provide hope within the Black community, especially among children who would see African Americans working in various positions. ${ }^{71}$ However, the employment situation was getting worse. ${ }^{72}$ In December 1945, Berry reported, "We have had practically no calls for male Negro labor in the last month." ${ }^{73}$ He continued soliciting ideas to increase awareness of African American employment difficulties. Berry spoke by phone with a State Department of Labor employee who, unaware that he was speaking with an African American, expressed discriminatory attitudes. ${ }^{74}$ As a result, Berry conducted a survey to provide the board with data on the attitudes of employers toward the inclusion of Black Americans in fields such as utilities and retail trades. Berry was convinced the survey would reveal that White citizens did not oppose African Americans serving them in retail

\footnotetext{
70 “MSSULP 1945 Meeting Minutes," Oregon Multicultural Archives, 24.

71 Ibid., 30.

72 Ibid.

${ }^{73}$ Ibid.

74 Ibid., 31.
} 
and utility fields. However, the survey provided the same negative reaction to Black workers. $^{75}$

Hope for increased employment opportunities came from a local tailor in 1946. Ray Bolger, a local business owner, contacted the Urban League with plans to start a tailoring company that would employ African American skilled workers. Bolger wanted to train Black men in his factory and then help them create their own Black owned businesses, adding he would be willing to financially assist with securing a building and equipment. ${ }^{76}$ Urban League board members discussed his proposal and approved it in principle. However, the business was never established. Ironically, Bolger did not hire African Americans to work in his already established tailoring business and his plan mirrored a separate-but-equal strategy.

The focus on employment offered some solutions. However, infighting among civic organizations created a rift between groups. In this way, no one group was solving the problem and African American unemployment continued to rise. The only way to resolve the employment problems was for civic organizations to collaborate on fair employment.

\section{Fair Employment Practices}

"The FEP law is recognition of the right of all racial and religious minorities to earn their livings and improve their economic status, and

\footnotetext{
75 Ibid., 30.

76 “MSSULP 1946 Meeting Minutes," Oregon Multicultural Archives Oregon State University Libraries, Special Collections and Archives Research Center, 3.
} 
reaffirmation of that equality of citizenship which has been promised but not delivered under the American system. "77

League officials found a solution to the unemployment problem in February 1946, when Bolger's Black-run tailoring business failed to take off. The Urban League began cooperating with the NAACP in support of a state Fair Employment Practice Committee (FEPC) which pushed for fair employment practice legislation. Berry advised board members to take action by insisting they send letters of support to U.S. Senators Wayne Morse and Guy Cordon. The committee "Combined the talents of dedicated whites, blacks and other individuals of like mind and objectives." ${ }^{, 78}$ An independent citizens group provided momentum for a legislative bill to come after the formal creation of the committee. The Oregon Methodist Federation for Social Services initiated efforts but were unsure of their plans and how to get a bill moving. Cooperating with other organizations, the Urban League organized the new committee. ${ }^{79}$

The Fair Employment Practices Committee began organizing and holding meetings in October 1946. League members Don Green and Edwin Berry attended several marginally successful meetings. An orientation meeting provided a chance for members to get acquainted. The second meeting was more formal and two different bills were presented for proposal to the Oregon legislature. The first bill was limited as it only eliminated workplace discrimination in state and county employment. The second was more comprehensive, covering all public and private employees but excluding small

\footnotetext{
77 "Progress in Civil Rights," The Oregonian, March 22, 1949.

${ }^{78}$ Millner, On the Road to Equality, 13.

79 “MSSULP 1946 Meeting Minutes,” Oregon Multicultural Archives, 19.
} 
employers with six or fewer employees and religious, educational, and non-profit organizations. ${ }^{80}$ Berry worried that supporting the limited bill was a poor strategy politically because legislative modifications would further weaken the measure. ${ }^{81}$ After months of committee revising, the measure eventually proposed to the Oregon senate closely resembled the second bill. Prior to proposing the modified bill to the state legislature, committee members debated whether or not a civil rights bill would help more African Americans. The committee noted a civil rights bill would go further than a fair employment law in helping Black Americans. However, Senator Morse stated a fair employment practices law was better than losing the fight entirely. ${ }^{82}$ Supporters urged the FEPC not to push a civil rights bill until after an employment bill was passed, and the committee agreed. ${ }^{83}$

The Fair Employment Practice Committee introduced the measure prohibiting workplace discrimination to the senate in January 1949. The proposed measure prohibited employment discrimination on the grounds of race or religion, in businesses with five or more employees. Businesses would be accountable to a commission created by the governor. The measure was similar to one passed in New York which set up a commission that issued penalties for noncompliance. ${ }^{84}$ At a senate hearing opponents argued against the bill, "Attitudes of discrimination cannot be changed by law" and "the

\footnotetext{
${ }^{80}$ Ibid., 20.

${ }^{81}$ Ibid.

${ }^{82}$ Ibid., 5.

${ }^{83}$ Ibid., 4.

84 "Bill on FEPC Given Senate: Measure Strikes At Discrimination," The Oregonian, January 12, 1949, p. 8.
} 
public will not stand for Negroes serving them or working with them." 85 Supporters argued employment would increase living standards, therefore, change racial attitudes statewide and pointed to successful measures in New York, New Jersey, Massachusetts, Connecticut, and neighboring Washington State. ${ }^{86}$

Urban League members wrote letters to state senators as they rallied for the bill's passage. Berry urged the senate to pass the FEPA in a letter that called for moral leadership against the treatment of African American workers, asserting it was "uneconomical to permit our present discriminatory employment practices to go unchecked." ${ }^{87}$ He also urged Urban League members to be active in fair employment practice committees and in "assisting to create positive public opinion in connection with the bill." ${ }^{\prime 88}$ Berry was positive a fair employment bill would change local racial dynamics by providing African Americans with jobs. Feeling the enthusiasm, League president David Robinson created employment training opportunities and encouraged youth and adults to gain skills in order to be available for new positions once the bill was passed. ${ }^{89}$

The FEPA passed in March with overwhelming votes in the house of 53 to 4 and 27 to 2 in the senate, both completely white groups. ${ }^{90}$ Berry explained the passage as the

85 "FEPC Issue Considered By Senate: Discussion Orderly; 3-man Commission Provided Under Bill," The Oregonian, January 26, 1949, p. 1.

${ }^{86}$ Ibid. "Connecticut FEP Success, Rabbi Silverman Reports," The Oregonian, February 17, 1949, p. 4. "Oregon Sixth To Adopt FEP," The Oregonian, March 26, 1949, p. 1. 87 "Urban League Asks for FEP: Discrimination Hit By Berry Memo," The Oregonian, February 9, 1949, p. 8.

88 “MSSULP 1949 Meeting Minutes," Oregon Multicultural Archives, 1.

${ }^{89}$ Ibid., 3.

90 The first African American elected to the Oregon legislature was William McCoy in 1972. "Who's Who in the House: William McCoy." Oregon Voter Digest 58 (24): 122123. December 15, 1972. 
"greatest weapon" in their arsenal against the unemployment of African Americans. ${ }^{91}$ The passage of the Oregon Fair Employment Practices Act (FEPA) demonstrated the success of intergroup collaboration and the Oregonian titled it "Progress in Civil Rights," marking an Urban League victory. ${ }^{92}$ NAACP president Otto G. Rutherford told national leadership, "With the presence of an F.E.P. law on Oregon books, employment and job opportunities are considerably better and steadily improving." 93 The interracial FEP committee was the principle sponsor of the bill that demonstrated intergroup collaboration as a strategy to pass fair employment practices legislation. The need for cooperation would be important in passing a public accommodations act in the coming months.

\section{"This is a Radical Measure"}

"This is no more radical than the Bible, the Constitution, or the United Nations' Charter. It is no more radical than the exciting and inspiring concepts of brotherhood, equality and human dignity. "94

Urban League membership had spent three years working on a fair employment practices law in which they gained organizational allies. The next step to equality was the passage of a public accommodations law. The NAACP and City Club recommended the

\footnotetext{
91 "Progress in Civil Rights," The Oregonian, March 22, 1949, p. 9; "MSSULP 1949 Meeting Minutes," Oregon Multicultural Archives, 3.

92 "Progress in Civil Rights," Oregonian, 9.

${ }^{93}$ Otto G. Rutherford, "Otto G. Rutherford to Franklin H. Williams," Verdell Burdine and Otto G. Rutherford Family Collection 1880s-1980s, Portland State University Special Collections.

${ }^{94}$ The Urban League, "Newsletter: Civil Rights," Verdell Burdine and Otto G. Rutherford Family Collection 1880s-1980s, Portland State University Special Collections.
} 
need for such a law in order to ease the racial discord in Portland. Armed with interracial activists and allies, the Urban League began a campaign to support the civil rights ordinance introduced by Mayor Lee.

By 1949, Urban League officials were poised for a campaign to support civil rights legislation. League president David Robinson circulated a draft civil rights referendum that prohibited places of public accommodation from discriminating against patrons due to race, color, religion, ancestry, or national origin. League members supported the measure and believed educating the public was vital to its success. Berry recommended focusing on dramatic local stories. The Urban League immediately began working for the bill by circulating flyers and brochures in the community. ${ }^{95}$

Berry believed intergroup collaboration was the top strategy in passing a civil rights bill. In early 1949, Berry asked for a list of interested organizations to create a committee to improve intergroup relations. He hoped to bring civic groups closer together and provide fluidity of information, as well as present "a unified front on significant issues." Board members tabled his idea. They offered three reasons not to form an intergroup committee in Portland. First, their previous efforts to form a committee met with "utter failure." Second, members believed their efforts were better used strengthening the Urban League rather than supporting an intergroup committee. Third, officials thought League staff should be informing other organizations of their efforts instead. ${ }^{96}$ The lack of cooperation exhibited by league members must have

95 “MSSULP 1949 Meeting Minutes," Oregon Multicultural Archives, 7. 96 Ibid., 5. 
frustrated Berry as he was on the executive board of the NAACP and a board member of the Anti-Defamation League, not to mention that Berry had just seen the benefits of cooperation on the passage of the FEP law.

Next Strategy: Berry created informational pamphlets and flyers to educate the public on civil rights and public accommodations. Berry believed the Urban League's Community Education Committee was the first to advocate "positive social action" through education by promoting "the Urban League, [and] its philosophy to the people of Portland." 97 The goal of the committee was to publish facts about African American issues to educate the general public about civil rights. The education committee began distributing flyers and pamphlets to areas adjacent to Black neighborhoods. "Don’t be Misled...About Your Neighbors!" read one flyer that tried to dispel the myth that African American homeownership lowered neighborhood property values. ${ }^{98}$ Another flyer offered "Ten Tips To Tactful Talkers," which urged the reader to "avoid racial jokes" and “don't talk about your colored mammy." 99 The mayor's committee on civil rights, as well as the City Club committee, requested these pamphlets to include in their reports. ${ }^{100}$ Other organizations became involved in Berry's informational campaign, even if league members did not want to unite.

97 Ibid., 13.

98 "Don't be Misled...About Your Neighbors," The Urban League of Portland 1949, Verdell Burdine and Otto G. Rutherford Family Collection 1880s-1980s, Portland State University Special Collections and University Archives.

99 "Ten Tips for Tactful Talkers," The Urban League of Portland 1949, Verdell Burdine and Otto G. Rutherford Family Collection 1880s-1980s, Portland State University Special Collections and University Archives.

100 “MSSULP 1949 Meeting Minutes,” Oregon Multicultural Archives, 39. 
Other civic organizations began to increase awareness of the need for civil rights legislation as rumors of a local bill began to circulate. At the Progressive Party meeting in 1949, NAACP president Marie B. Smith declared, "We are Americans and it is true that at this time we do not enjoy full American citizenship. At no time have we refused to accept full responsibility as citizens." ${ }^{101}$ In February 1950, a proposal by a citizens committee for civil rights was presented to the Portland City Council "prohibiting racial discrimination in city-licensed restaurants, hotels, theaters and other businesses." The state assembly was rumored to also be drafting legislation to prohibit discrimination based on race, color, or creed. Local business owners countered that such legislation was invasive of owner's rights. ${ }^{102}$

The NAACP organized meetings to educate the public on tolerance and civil rights. The organization invited Saal Lesser, Anti-Defamation League executive secretary for Oregon, Idaho, and Montana, to speak on eliminating racial prejudice. Lesser was optimistic about the bill, citing the successful passage of anti-discrimination bills across the country. He urged members to work harder at educating the public on the virtues of civil rights. ${ }^{103}$ NAACP National Secretary Walter White again visited the Rose City in 1950, speaking on the "Color Line Across the Globe." 104 These activities were an attempt

\footnotetext{
101 "NAACP Head Outlines Aims: Robeson Statement Elicits Answer," The Oregonian, May 11, 1949, p. 13. 102 "Equal Rights," The Oregonian, January 8, 1949, p. 6.

103 "City Exhorted On Tolerance: Saal Lesser Talks to NAACP Parley," The Oregonian, February 20, 1950 p. 14.

104 “Talk Scheduled By Walter White,” The Oregonian, July 30, 1950 p. 16.
} 
to increase membership. However, it also gave the organization a chance to educate the public on the upcoming civil rights bill.

In 1950, the NAACP began a final promotion of civil rights education as the November vote neared. A meeting organized by the organization offered "An explanation of the proposed civil rights ordinance [and] a summary of the reason for supporting it."105 The forum allowed members and non-members a space to discuss the upcoming ballot proposal. Director of the NAACP and member of the Oregon State Committee on Fair Employment Practices Ulysses G. Plummer spoke to a crowd at the Williams Avenue YMCA. Plummer explained the importance of voting for equal public accommodations. Mrs. Arthur Green, Legislative Chairman of the Oregon Congress of Parents and Teachers spoke on the importance of civil rights education in public schools. ${ }^{106}$

In an attempt to educate White readers, John M. Dhyr, chairman of the Oregon Civil Rights Congress, wrote to the editor of the Oregonian. Dhyr asked readers to think about discriminatory practices in public businesses that denied access to "eating, recreation, entertainment and hospitalization solely upon the basis of race, color, creed or national origin." ${ }^{107}$ Dhyr pointed to the experience of Carol Brice, an African American artist who appeared with the Portland Symphony and was refused service in two Portland restaurants. It was not uncommon for Black Americans to find "white trade only" signs in downtown businesses, and many Black entertainers stayed with Black families because

105 "Civil Rights Parley Nears: Meeting to Push Ballot Proposal," The Oregonian, September 17, 1950 p. 18.

106 "Schools, Rights To Be Discussed," The Oregonian, October 15, 1950 p. 23.

107 John M. Dhyr, "Equal Rights,” The Oregonian, January 13, 1949, p. 6. 
hotels denied them service. For example, as an undergraduate at Willamette University in Salem, future Oregon governor and senator Mark O. Hatfield drove Black entertainer Paul Robeson to Portland after he was denied accommodations in Salem. Hatfield was stunned by the experience and would later support accommodations legislation. ${ }^{108}$ Dhyr concluded that, "The enactment of the proposed city ordinance... will be in keeping with the American tradition of justice and fair play for all our people." 109

The Oregonian reported that "Whether or not a civil rights ordinance was passed would depend on how much community education there was and to what extent community organizations had been sensitized and activated." ${ }^{110}$ With one last push as the vote neared, Berry tried to persuade members to join other organizations in an attempt to secure support for the measure. However, membership stagnated in the months leading up to the November vote.

In a final effort, organizations bought advertising space in the Oregonian to sway last minute voters. One advertisement displayed slippery slope fallacies which tugged at the hearts of readers. "Who Hurt This Child?" read the Oregonian advertisement five days prior to the vote. The advertisement depicted an African American girl looking at a cat who was eating melted ice cream which dripped from her hand. The text read, "You'd be hurt, too, if you were in the second grade and just got a "star" for saying the pledge to the flag right...then it was noon hour. You'd run across the street with the others to buy ice cream at the store. That was when your whole world turned dark...dark as your hand

\footnotetext{
108 Jon Tuttle, Local Color, Oregon Public Broadcasting, May 1, 1999.

${ }^{109}$ Dhyr, "Equal Rights," 6.

${ }^{110}$ Ibid., 29, 39.
} 
that held that precious nickel. You'd had to eat your ice cream alone... outside on the sidewalk. Wouldn't you be hurt, too? Let's stop doing this in Portland!"111 The advertisement dramatically depicted a real life situation which appealed to the hearts of readers. Voters assumed children were affected by racial bias, and these advertisements illustrated the heartbreak of most Black parents.

Another advertisement appealed to voter's nationalism and commitment to civic duty. "As George Washington once said, 'Let us raise up a standard to which the wise and just may repair..." the ad read. "Let each of us with our vote, do what is RIGHT, what is JUST, what is FAIR to all." The advertisement urged voters to do what was right, just, and fair while they were in the voting booth on Election Day. Quoting George Washington preyed upon nationalistic emotions proving how important donors and activists believed this vote to be. The ad concluded with two sentences explaining how a voter should vote his or her conscience because no one was looking over their shoulder in the voting booth. Their civic duty was to vote for justice "because this is America...It isn't a complicated decision."112

Organizations waited to see if their efforts over the past five years would prove fruitful in the passage of a civil rights ordinance on the November ballot. Berry and Robinson attended various speaking engagements in the days preceding the election to urge the bill's passage. Multiple groups continued to ask for the Urban League for more educational material, the league's only demonstration of cooperation. After five years of

111 “Who Hurt This Child?” The Oregonian November 2, 1950 p. 10.

112 "This is Right, This is Just, This is Fair," The Oregonian November 6, 1950, p. 6. 
working on fair employment legislation, segregation, and general discrimination, the Urban League believed the vote was in their favor. They were instrumental in organizing the Oregon FEPC which, by all accounts, was a success. There was no reason for organization members to believe the Civil Rights Ordinance would not be a success. They were shocked when the ordinance failed to pass. 


\section{Conclusion}

“Civil Rights Losing” read the Oregonian headline on November 8, 1950.

Portland's civil rights ordinance lost by over five thousand votes when the ballots from 403 precincts were counted. ${ }^{1}$ Several days prior to the election, Oregonian reporter William Mayes told readers he had spoken with a local politico who said, "Civil Rights will be beaten by a ratio of sixty percent." ${ }^{2}$ Whoever the politico was, the prediction was very close as the measure lost by fifty-five percent. The public had struck down the measure.

Criticism of the ordinance by white citizens showed how hostile opposition to the measure had become. A. G. Hunt of Springfield, Oregon, wrote to the Oregonian, "My wife and I often go to Portland to shop and for entertainment and while there we prefer associating with our own race because we are happier in our own environment." ${ }^{3}$ In another, F. I. Snow of Albany, Oregon explained, "God set the nations and the races apart, and other ways must be found to solve the problem of the colored people than trying to force one race upon another by law." ${ }^{4}$ Francis H. Ames of Rose Lodge, Oregon, wrote that the reason the public voted against it was because, "They believed in a hotel or restaurant owner's American right to refuse service to anyone. A Negro-operated restaurant also has the right to refuse service to whom it may see fit and such right should

\footnotetext{
1 "Morse, McKay Swamp Opponents; Civil Rights Losing, Bennett Leads," The Oregonian, November 8, 1950, p. 1.

${ }^{2}$ William Mayes, "Behind the Mike," The Oregonian, November 3, 1950, p. 4.

${ }^{3}$ A. G. Hunt, "'God's Plan'," The Oregonian, April 2, 1950, p. 7.

${ }^{4}$ F. I. Snow, "Racial Problem," The Oregonian, April 19, 1950.
} 
never be taken away in this country." Jesse B. Helfrich stated, "I am opposed to this ordinance because I believe it is unconstitutional." ${ }^{6}$ Other letters expressed similar sentiments as white writers justified not voting in favor of the Civil Rights ordinance.

Oregonian staff writer Wallace Turner laid out voting statistics for the measure in Portland. The majority of affirmative votes came from areas around the University of Portland and Reed College. Other precincts of well-educated voters such as Ladd's Addition, Irvington, Laurelhurst, and Mount Tabor voted in favor of the ordinance. Precincts voting against the ordinance were located north of Fremont Street, where low income residents of mixed racial makeup lived. Low income White residents living next door to African Americans voted two-to-one against the ordinance in these areas. Urban League secretary Edwin Berry explained, "Here we see an area of lower middle and middle class white residents - many of who identify social status with racial isolation."7 Not only were they neighbors, but they were fighting for the same employment opportunities, housing, and status. According to historian Rudy Pearson, low income Whites frustrated with their poor employment outlook blamed their Black neighbors for low wages, unemployment, and low property values. ${ }^{8}$

National civil rights leadership detailed successes in the face of the loss. Franklin H. Williams, West Coast Regional Director of the NAACP, spoke to the local branch

${ }^{5}$ Francis H. Ames, "Conduct of Negroes," The Oregonian, November 17, 1950.

${ }^{6}$ Jesse B. Helfrich, "Race Ordinance," The Oregonian, November 5, 1950, p. 29. Helfrich's letter criticized Hazel Scott, a popular Black musician, who was denied service in Pasco, Washington and later sued the restaurant and received a settlement.

${ }^{7}$ Berry, "Why the Civil Rights Ordinance Did Not Pass," Portland State University Special Collection, 1.

${ }^{8}$ Rudy Pearson, "A Menace to Society," 174. 
after the vote. His message centered on the continued fight for civil rights despite the loss. ${ }^{9}$ To boost morale, Williams focused on "Outstanding recent gains against racial discrimination and segregation in the southern and border states." ${ }^{10}$ In an Urban League newsletter Edwin Berry listed the positive results of the civil rights campaign. He explained that proponents of civil rights now knew where they stood and where work needed to be done. He suggested some members were complacent and the loss proved they needed to work harder. Berry exclaimed, "We emerge from the effort with new vigor, and new determination; with a great many friends and some fresh leadership. The campaign made an impression on Portland which will never be forgotten." ${ }^{11}$ Leadership could not afford to focus on failings, instead they needed to identify what went wrong and how to change it.

Leadership blamed insufficient educational efforts for the defeat of the Civil Rights ordinance. Mayor Dorothy McCullough Lee's head of Intergroup Relations committee, Dr. Myron C. Cole, inferred the bill failed due to a lack of education. ${ }^{12}$ Berry explained to members in a monthly newsletter that the Urban League failed to educate the public. He pointed to their lack of a grassroots effort due, in part, to advocates not knocking doors or canvasing neighborhoods. ${ }^{13}$ The City Club, NAACP, and Urban League had focused their efforts on speaking to the public; however, they only reached

9 “Court Victories Speaker's Topic,” The Oregonian, November 18, 1950 p. 10.

10 “Speaker Cites Racial Gains," The Oregonian, November 21, 1950 p. 19.

${ }^{11}$ Berry, "Why the Civil Rights , 3.

12 "Education on Civil Rights to Draw Committee Stress," The Oregonian, November 10, 1950, p. 11.

${ }^{13}$ Edwin C. Berry, "Why the Civil Rights Ordinance Did Not Pass," Portland State University Special Collection, 1 
an audience that already agreed with them. Berry summed up the problem when he wrote, "Many of us spent such an overwhelming amount of time raising money for this educational job that we didn't have time to actually do the educational job."14 Leadership believed a lack of community education was one factor for the failure of the ordinance.

A second factor for the failure was that organizations failed to collaborate fully. Berry advocated for increased cooperation between all organizations. He explained an effective campaign was going to take a "wide spread effort" in unions, lodges, and professional organizations. ${ }^{15}$ Berry pointed to a successful campaign carried out by the interracial intergroup, United Committee for Civil Rights, which "achieved the highest degree of organization and cooperation." ${ }^{16} \mathrm{He}$ urged cooperation between the Urban League and other civic groups in an effort to see change similar to which other areas in the West. ${ }^{17}$

Oregonian writer Hugh A. Scott claimed racial attitudes were changing in the Rose City. He detailed poor housing, overcrowding, unemployment, and overall prejudice. However, gains in education had helped African Americans find jobs. Scott added, "In 1950, half of Portland's Negro high school graduates entered college," which was above the national average. ${ }^{18}$ Scott expressed that he felt a change in the air for the

\footnotetext{
${ }^{14}$ Ibid., 2. Emphasis included in document.

${ }^{15}$ Ibid.

${ }^{16}$ Ibid.

${ }^{17}$ Whitaker, Race Work, 4-5.

${ }^{18}$ Hugh A. Scott, "Lot of Negro in Portland Still Long Way from Perfect," The Oregonian, April 16, 1952, p. 11.
} 
Black community, foreshadowing the coming of a successful state accommodations law. ${ }^{19}$

Although attitudes were changing in Portland, racial discrimination continued to persist. In 1951, DeNorval Unthank, Jr., was attending the University of Oregon and courting Doris Burgess, a White sorority sister from Gamma Phi Beta. One evening in May, Doris awoke to yelling and a flaming cross on the front lawn. One of the perpetrators shouted, "Hey, nigger-lover. You like him?" Terrified, Burgess ran to the hallway telephone to check on Unthank, worried the perpetrators would continue to his home. Unthank assured her that he would be fine. After the cross burning on the Gamma Phi lawn, Burgess met with sorority alumnae who plainly stated, "In our society, a Negro boy dating a White girl is not accepted. The Portland alumnae demand that the house take action. If you continue to see that man, you will be asked to leave the house." ${ }^{20}$ The following day Burgess moved out of the sorority and into a dormitory where she was informed that Unthank could not enter. In July the couple drove to Vancouver to get married because Oregon prohibited interracial marriage. After all the work that civic organizations had put in, racial discrimination persisted throughout the state.

Not satisfied with the loss of the ordinance, organizations began a campaign for another civil rights bill, this time at the state level. Organizations began collaborating more than during the 1950 campaign. The Urban League encouraged the membership to

\footnotetext{
19 Ibid.

${ }^{20}$ Deb Mohr, "Cross Burning at Gamma Phi Beta," Oregon Quarterly, 2014, accessed June 6, 2016, http://oregonquarterly.com/cross-burning-at-gamma-phi-beta. Underline added for emphasis.
} 
"Support our Allies," recommending members join and support the NAACP, FEPC, and the Anti-Defamation League. NAACP leadership urged board members to support other organizations as far away as Pendleton, Oregon. They also suggested a few areas of improvement for members, including grassroots efforts and speaking with their neighbors about race relations. ${ }^{21}$ By the end of 1951, civic organizations supported each other in cross membership drives. ${ }^{22}$ Civic groups began following Berry's counsel, and rather than competing for members, they worked together.

In January 1953, Oregon State Senators Philip Hitchcock and Mark O. Hatfield sponsored the Oregon Civil Rights bill. In April, Portland civic organizations presented a letter to the Oregon state legislature urging them to adopt a statewide civil rights ordinance. NAACP attorney Ulysses G. Plummer read the letter to the house and senate in hopes of gaining support for the public accommodations bill banning discrimination on the basis of race, religion, color, creed, or national origin. Plummer stated, "That certain individuals do discriminate and shall continue to discriminate against a particular class in Oregon is suspect and immediately raises the need for a law, such a law as is now before you." ${ }^{23}$ The law gave "full and equal accommodations, advantages, facilities and

${ }^{21}$ Verdell Rutherford, "NAACP Executive Board Meeting Minutes 1951" Verdell Burdine and Otto G. Rutherford Family Collection 1880s-1980s, Portland State University Special Collections.

22 "Williams Ave YWCA" Verdell Burdine and Otto G. Rutherford Family Collection 1880s-1980s, Portland State University Special Collections.

${ }^{23}$ Ulysses G. Plummer, “The Property Rights Question in Civil Rights Legislation Proposal," Verdell Burdine and Otto G. Rutherford Family Collection 1882s-1980s, Portland State University Special Collections. 
privileges of any place of public accommodation." The law also made the offense a misdemeanor and required the perpetrator pay a fine for noncompliance. ${ }^{24}$

Organizations pushed their members to get involved to avoid watching another bill fail. Civic leaders urged their membership to write senators in support of the bill, but as the vote passed through the senate some leaders worried it would not pass the house. Several senators received opposing views from concerned citizens and businesses asking them to vote against the measure. ${ }^{25}$ Afraid that the opposition could sway the vote, the NAACP and Urban League sent a group to the capital to speak to state representatives. NAACP activist Edgar Williams sought out House Speaker Rudie Wilhelm after learning he was not interested in the Black vote. Williams spoke with Wilhelm about the importance of a statewide bill and Wilhelm assured him that he would vote in favor of the measure. Later Wilhelm told a staff member he voted in favor of the law because of his interaction with Williams, which was crucial because Wilhelm "was responsible for the bill passing the house with a majority of better than 4 to $1 .{ }^{\prime 26}$ The struggle for civil rights in Portland finally culminated in the passage of a statewide law designed to provide equality in public accommodations.

\footnotetext{
${ }^{24}$ Philip Hitchcock, "Senate Bill No. 169," Forty-Seventh Legislative Assembly, Verdell Burdine and Otto G. Rutherford Family Collection 1880s-1980s, Portland State University Special Collections.

${ }^{25}$ Monroe Sweetland, "Correspondence to Lafe Compton," Verdell Burdine and Otto G. Rutherford Family Collection 1880s-1980s, Portland State University Special Collections. Monroe Sweetland, "Correspondence to Oregon Licensed Beverage Association," Verdell Burdine and Otto G. Rutherford Family Collection 1880s-1980s, Portland State University Special Collections.

26 "Edgar Williams Notecard," Verdell Burdine and Otto G. Rutherford Family Collection 1880s-1980s, Portland State University Special Collections.
} 
The civil rights law marked a major milestone in the struggle for civil rights in Oregon. In a letter to the national office, NAACP branch president Otto Rutherford stated that the law's passage was their most outstanding accomplishment. ${ }^{27}$ An Urban League newsletter touted the public accommodations law as the group's "most important accomplishment in the past twelve months." 28 Organizations saw the passage of a bill that they believed would provide equal footing for all citizens. Although the passage of the public accommodations law marked an important moment for civil rights organizations, it did not change racial attitudes in Portland. Otto Rutherford explained how "white trade only" signs were banned from Oregon businesses. However, discrimination was practiced in more covert forms such as poor service. ${ }^{29}$ Housing and education segregation continued to prevent African Americans from living in middle class neighborhoods or gaining better employment. The African American experience of racism and discrimination continued almost unfettered, making the 1960s and 1970s an essential period for local civil rights historians.

Nonetheless, the passage of the 1953 civil rights bill demonstrates the importance of the era leading up to the classical phase of the civil rights movement. In this era, strong leaders and activists struggled against discrimination in public accommodations as well

${ }^{27}$ Otto G. Rutherford, "Activities of Church Work Committee," Verdell Burdine and Otto G. Rutherford Family Collection 1880s-1980s, Portland State University Special Collections.

28 "Race Relations, 1954," Verdell Burdine and Otto G. Rutherford Family Collection 1880 s-1980s, Portland State University Special Collections.

${ }^{29}$ Nadine Jelsing, "Portland Civil Rights: Lift Ev'ry Voice." Oregon Public Broadcasting August 18, 2015, accessed May 23, 2016, http://www.opb.org/television/programs/oregonexperience/segment/portland-civil-rightslift-evry-voice/. 
as in other areas. These struggles were a response to rising racial tensions between a growing community of African Americans and an established White community working to keep the status quo. Several organizations highlighted the reasons for rising tensions, but the City Club of Portland reports demonstrated interracial cooperation and an attempt to educate the White community. The Urban League, NAACP, and City Club identified strategies to change public perceptions of African Americans. Intergroup collaboration, interracial cooperation, and education became the basis for change which eventually led to the statewide accommodations law.

These factors make this era significant not only for Portland civil rights but the national movement as well. The struggle for equality in Portland shows the experience started before the classical phase in 1954. The experiences of local leaders also provide a uniquely Pacific Northwest experience characterized by a rapid increase of Black laborers for wartime production which immediately decreased at the end of the war. Much like Spokane, Washington, as historian Dwayne Mack indicates, it was necessary for African American leaders to find allies within the White community to progress equality. Without interracial cooperation and intergroup collaboration the 1953 law would not have passed.

Most Oregon civil rights histories begin with the development of Vanport and move quickly through the passage of the accommodations law before addressing the 1960s and 70s. However, the 1945 to 1953 struggle for civil rights in Portland and Oregon demonstrates the rise of local leaders, wartime racial tensions, and organizational strategies used to combat inequality. 1945 marked a watershed in civil rights history in 
Portland with intergroup collaboration and interracial cooperation converging to eventually provide needed legislation. Although discrimination continued after 1953, the era between 1945 and 1953 provided an era of change upon which subsequent movements were based. By focusing on the turbulent classical phase of civil rights, we miss the building of a strong foundation for Portland's civil rights history. 


\section{Bibliography}

\section{Primary Sources, Newspapers, and Government Documents}

Adams, R. A. "Basic Freedom," The Oregonian November 18, 1950.

“Alta Smith Corbett,” The Oregonian, September 10, 1976 p. 50.

Ames, Francis H. “Conduct of Negroes," The Oregonian November 17, 1950.

Bender, Manya. "Unity Urgent," The Oregonian, February 18, 1945, p. 17.

“Benefit Play Announced," The Oregonian, April 6, 1933, p. 7.

Berry, Edwin C. "Letter to the Editor," The Observer May 31, 1945, p. 4.

Berry, Edwin C. "Why the Civil Rights Ordinance Did Not Pass," Verdell Burdine and Otto G. Rutherford Family collection, 1880s-1980s. Portland State University Special Collections.

"Bill on FEPC Given Senate: Measure Strikes At Discrimination," The Oregonian January 12,1949, p. 8.

“'Birth of a Nation' Thrills: Heilig Audience Awed by Historical War-Time PhotoDrama," The Oregonian September 5, 1915 section 4, p. 2.

Cannady, Beatrice Morrow. "Film is Protested: Negroes Oppose Showing of 'The Birth of a Nation' Appeal Made to Churches," The Oregonian July 4, 1915, section 1, p. 3 .

Cannady, Beatrice Morrow. "A New Doctor," The Advocate, January 25, 1930, p. 1.

Cannady, Beatrice Morrow. "Portland Has New Doctor," The Advocate January 30, 1930, p. 1.

Cannady, Beatrice Morrow. "Negro Doctor to Speak at Bethel Saturday Nite," The Advocate January 30, 1930.

Cannady, Beatrice Morrow. "Vandals Break Windows in Doctors Home," The Advocate July 4, 1931.

Cannady, Beatrice Morrow. “'Birth of a Nation’ Barred From Portland: Many Groups Protest Exhibit," The Advocate, January 2, 1932, p. 1. 
"Carriers to see Film: 200 of the Oregonian Guests at 'Birth of a Nation' Tonight," The Oregonian September 10, 1915, p. 17.

Carter, Hodding. "The Other Side of 'Jim Crow': Slanting, Selectivity Charged in Painting Negro's Plight; South Claimed Gradually Easing Worst Racial Tensions," Democrat-Times, (Greenville Delta, Mississippi) found in The Oregonian, September 7, 1948, p. 6.

“Carter Speaks on Racial Problems," The Daily Herald (Biloxi, Mississippi), April 8, 1948, p. 9.

"City Club Accepts Study on Negro in Portland," The Observer August 17, 1945, p. 4.

"City Exhorted On Tolerance: Saal Lesser Talks to NAACP Parley," The Oregonian February 20, 1950 p. 14.

“City News in Brief: Minority Groups," The Oregonian October 12, 1944, p. 11.

"City News in Brief: Seattle League Leader Here," The Morning Oregonian February 19, 1931, p. 9.

“City to Probe Negro's Death,” The Oregonian, September 8, 1945, p. 7.

“Civil Rights.” Portland City Club Bulletin 31, no. 20 September 22, 1950.

“Civil Rights Bill To Be Debated," The Oregonian, January 24, 1945, p. 9.

"Civil Rights Law Indorsed: City Club Members Uphold Committee," The Oregonian, September 30, 1950, p. 7.

"Civil Rights Parley Nears: Meeting to Push Ballot Proposal," The Oregonian September 17,1950 p. 18.

“Clinic Examines 20 Negro Babies,” The Oregonian April 21, 1939.

“Community Row Settled,” The Morning Oregonian July 18, 1931.

“Connecticut FEP Success, Rabbi Silverman Reports," The Oregonian February 17, 1949, p. 4.

Connelly, Gordon M. "Witness for Purcell," The Oregonian, October 31, 1945, p. 12.

“Court Victories Speaker’s Topic,” The Oregonian November 18, 1950 p. 10. 
"Death Penalty Fought: Demonstrators Oppose Hanging of Confessed Slayer," The Oregonian, February 21, 1934, p. 14.

“Death Sentence Protested," The Oregonian, April 25, 1934, p. 16.

"Death Sentence Upheld: Slayer Of Pullman Conductor Loses Appeal," The Oregonian, November 10, 1933, p. 8.

"Defense Group to Meet," The Oregonian, September 13, 1933, p. 11.

Dhyr, John M. “Equal Rights,” The Oregonian, January 13, 1949, p. 6.

"Edgar Williams Notecard," Verdell Burdine and Otto G. Rutherford Family Collection 1880s-1980s, Portland State University Special Collections.

"Education on Civil Rights to Draw Committee Stress," The Oregonian November 10, 1950, p. 11.

Emerick, H.R. "Negroes and Whites," The Oregonian July 31, 1945, p. 6.

“Ervin Jones Inquest Set for October 19," The Observer September 20, 1945, p. 1.

"Equal Rights," The Oregonian, January 8, 1949, p. 6.

"FEPC Issue Considered By Senate: Discussion Orderly; 3-man Commission Provided Under Bill," The Oregonian January 26, 1949, p. 1.

“Girl Reserves Plan Meetings,” The Oregonian February 15, 1944, p. 8.

Goodman, Irvin. "Demand for an Official Investigation," The Observer, August 31, 1945, p. 4.

Goodman, Irvin. "Police Inquiry Asked," The Oregonian, September 5, 1945, p. 8.

“Groups Ask Tolerance,” The Oregonian, October 20, 1945, p. 9.

“Group Plans Luncheon,” The Oregonian October 25, 1944, p. 9.

“Group Plans Meeting,” The Oregonian October 13, 1944, p. 9.

"Group Raps Slaying Stand: Committee Hits Fleming Statement," The Oregonian, October 16, 1945, p. 9. 
"Hall Remarks Cause Shock: Race Situation Termed Unknown," The Oregonian, February 15, 1948, p. 19.

"Hall Denies Clemency for Killer: Governor Recalls 9-Day Court Trial, Other Legal Steps," The Oregonian, January 21, 1948, P. 1.

"Hall Refuses Conferences On Issuing Stay for Killer," The Oregonian, January 22, 1948, p. 9.

"Hall Remarks Cause Shock: Race Situation Termed Unknown," The Oregonian, February 15, 1948, p. 19.

"Harry S. Truman: Executive Order 9980," July 26, 1958. Online by Gerhard Peters and John T. Woolley, The American Presidency Project Accessed February 23, 2016, http://www.presidency.ucsb.edu/ws/?pid=78208.

Helfrich, Jesse B. "Race Ordinance,” The Oregonian November 5, 1950, p. 29.

Hitchcock, Philip. 1953. "Senate Bill No. 169," Forty-Seventh Legislative Assembly, Verdell Burdine and Otto G. Rutherford Family Collection 1880s-1980s, Portland State University Special Collections.

"Hodding Carter Praises Proposed Amendment for Proportionate Voting," Advocate (Baton Rouge, Louisiana), August 11, 1948, p. 2.

Holmes, Edith Knight. "'The Birth of a Nation' is Superb: Pictorial History of Civil War at Heilig is Triumph in Film Production," The Oregonian August 9, 1915, section 4, p. 3.

"Howard F. Kessler," The Oregonian January 9, 1968, p. 1.

Hunt, A. G. “'God's Plan',” The Oregonian April 2, 1950, p. 7.

Ingersoll, Carrie L. to Bagnall, Robert W. March 4, 1931, NAACP PB in Kimberley Mangun, A Force for Change: Beatrice Morrow Cannady and the Struggle for Civil Rights in Oregon, 1912-1936 (Corvallis: Oregon State University Press, 2010), 133.

"Inquest Jury Hears How Negro Died in Police Raid," The Oregonian, October 10, 1945, p. 1.

"Interior Post Beckons Two," The Oregonian July 14, 1946, p. 12. 
"Jordan and Riley Saved From Death: Meier Commutes Sentences to Life Imprisonment," The Oregonian, July 3, 1934, p. 5.

"Jordan Appeal Planned: Petitions To Be Prepared," The Oregonian, November 11, 1933, p. 12.

“Jordan Files Appeal," The Oregonian, June 3, 1933, p. 10.

“Jury Upholds Jones Action,” The Oregonian, October 19, 1945, p. 1.

"Labor Defense to Meet," The Oregonian, June 25, 1933, p. 11.

“Labor's Post War Program for Portland,” The Oregonian April 28, 1945.

Leas, Maude B. "YWCA on Racial Relations," The Oregonian, October 27, 1945, p. 8.

"Legal Aid Rapped," The Oregonian, November 11, 1945, p. 15.

"Leslie Unthank Transcript," last modified May 7, 2010, accessed June 1, 2014, http://www.eliotoralhistories.com/transcripts.html.

"Line up on the Right Side," The Oregonian, November 6, 1950, p. 28.

“Man Named By Governor,” The Sunday Oregonian January 18, 1942, p. 21.

Mayes, William. “Behind the Mike,” The Oregonian November 3, 1950, p. 4.

McClendon, William H. “Oregon's JUSTIFIABLE HOMICIDE,” The Observer, September 20, 1945, p. 4.

Mohr, Deb. "Cross Burning at Gamma Phi Beta," Oregon Quarterly, 2014, accessed June 6, 2016, http://oregonquarterly.com/cross-burning-at-gamma-phi-beta.

Moore, Walter B. "Civil Rights," Portland City Club Bulletin, 31, no. 20 September 22, 1950, City Club of Portland.

"Morse, McKay Swamp Opponents; Civil Rights Losing, Bennett Leads," The Oregonian November 8, 1950, p. 1.

“Most Negroes Seen Staying," The Oregonian, September 20, 1945, p. 7.

Moxness, Ron. "Negroes in Portland: What Is Their Postwar Outlook?" The Oregonian June 17, 1945, p. 54. 
Moxness, Ron. "Negroes in Portland: What Is Their Postwar Outlook?" The Oregonian June 24, 1945, p. 49.

“MSSULP 1945 Meeting Minutes," Oregon Multicultural Archives Oregon State University Libraries, Special Collections and Archives Research Center.

“MSSULP 1946 Meeting Minutes," Oregon Multicultural Archives Oregon State University Libraries, Special Collections and Archives Research Center.

“MSSULP 1947 Meeting Minutes," Oregon Multicultural Archives Oregon State University Libraries, Special Collections and Archives Research Center.

“MSSULP 1948 Meeting Minutes," Oregon Multicultural Archives Oregon State University Libraries, Special Collections and Archives Research Center.

“MSSULP 1949 Meeting Minutes," Oregon Multicultural Archives Oregon State University Libraries, Special Collections and Archives Research Center.

“NAACP Branch Prepares Drive,” The Oregonian April 2, 1950 p. 13.

"NAACP Head Outlines Aims: Robeson Statement Elicits Answer," The Oregonian, May 11, 1949, p. 13.

“NAACP Head to Speak Here," The Oregonian, January 16, 1946, p. 11.

“Negro Asked to Move,” The Morning Oregonian April 30, 1931.

"Negro Admits Attack," The Oregonian, June 6, 1932, p. 2.

"Negro to Face Grand Jury," The Oregonian, August 24, 1945, p. 6.

"Negro Reaches Prison," The Oregonian, December 15, 1932, p. 11.

"Negro Social Aim Furthered," The Oregonian June 12, 1944, p. 9.

"Negro Under Death Verdict Made Oregon Cause Celebre," The Oregonian, May 3, 1934, p. 4.

"Negro Work Problems Seen For Portland, Vancouver," The Oregonian February 13, 1944, p. 10.

“Negroes Fight Ban by Unions," The Oregonian December 6, 1941, p. 10.

"Negro Leader Lauds Ruling," The Oregonian October 8, 1942, p. 12. 
"Negroes Rap Dixie Revolt, Renew Racial Equality Bid," The Oregonian, March 22, 1948, p. 8.

"New Deal Given,” The Oregonian, February 14, 1934, p. 6.

"Officer Says Shot Fired to Save Partners on Raid," The Oregonian, September 11, 1945, p. 2.

“Ohioan Named Temple Aide," The Oregonian January 29, 1943.

“Olds Manager Named Officer," The Oregonian, April 27, 1945, p. 23.

“Oregon Convict Given Freedom After 22 Years," The Seattle Times, May 25, 1954, p. 7.

Oregon Death Index, “Wardell H. Henderson,” January 23, 1948 Marion, Oregon, 882.

“Oregon Sixth To Adopt FEP,” The Oregonian March 26, 1949, p. 1.

"Pardon Asked for Slayer: Racial Prejudice Charged in Plea," The Oregonian, April 9, 1952, p. 8.

"Parole Seen For Jordan," The Oregonian, May 13, 1954, p. 1.

"Pastors Asked to Aid Negro," The Oregonian, September 2, 1945, p. 10.

"Pleas Saved Life; Jordan Now Free," Omaha World-Herald (Omaha, Nebraska), May 25, 1954, p. 14.

Ulysses G. Plummer, "The Property Rights Question in Civil Rights Legislation Proposal," Verdell Burdine and Otto G. Rutherford Family Collection 1882s1980s, Portland State University Special Collections.

"Police Raid Slaying Justified, Jury Says: Detective Killed Negro Householder While on Hunt for Murder Suspect," The Oregonian, October 11, 1945, p. 1.

"Police Obtain Statement Thomas in Jones House," The Oregonian, October 14, 1945, p. 18.

"Portland Negroes Set Up Local Urban League Unit," The Oregonian November 25, 1944, p. 7.

"President of YMCA," The Oregonian November 28, 1928, p. 11. 
"Probe Backed by Churches," The Oregonian, September 13, 1945, p. 9

"Promotions Manager Smith Wins Promotion," The Oregonian April 5, 1931.

"Race Bigotry Draws Attack," The Oregonian, p. 4.

"Race Planning Soon To Start: Urban League Set To Aid Negroes," The Oregonian June 27, 1945, p. 9.

"Race Relations, 1954," Verdell Burdine and Otto G. Rutherford Family Collection 1880s-1980s, Portland State University Special Collections.

"Races Equal, Savant Holds: Opportunity Lack Seen as Problem," The Oregonian November 29, 1945, p. 7.

"Racial Issues Cause Dissent," The Oregonian, August 11, 1944, p. 9.

"Racial Study Lauds Groups: City Club Survey Urges Civic Action," The Oregonian, July 20, 1945, p. 9 .

“Racial Peace Declared Key,” The Oregonian, February 7, 1946, p. 11.

Rutherford, Otto G. 1954. "Otto G. Rutherford to Franklin H. Williams," Verdell Burdine and Otto G. Rutherford Family Collection 1880s-1980s, Portland State University Special Collections.

Rutherford, Otto G. 1954. "Activities of Church Work Committee," Verdell Burdine and Otto G. Rutherford Family Collection 1880s-1980s, Portland State University Special Collections.

Rutherford, Verdell. "Personal Sketch," Verdell Burdine and Otto G. Rutherford Family collection, 1880s-1980s. Portland State University Special Collections.

Rutherford, Verdell. "DeNorval Unthank M.D. Biographical Data," Verdell Burdine and Otto G. Rutherford Family Collection 1880s-1980s. Portland State University Special Collections.

Rutherford, Verdell. 1951. "NAACP Executive Board Meeting Minutes." Verdell Burdine and Otto G. Rutherford Family Collection 1880s-1980s, Portland State University Special Collections.

“Schools, Rights To Be Discussed," The Oregonian October 15, 1950 p. 23. 
Hugh A. Scott, "Lot of Negro in Portland Still Long Way from Perfect," The Oregonian April 16, 1952, p. 11.

Shoemaker, Mervin. "Law Bars Race Discrimination in Washington," The Oregonian October 9, 1950 p. 11.

Shoemaker, Mervin. "Law, Civic Effort Slowly Ease Seattle Racial Bias," The Oregonian October 11, 1950 p. 16.

Snow, F. I. "Racial Problem," The Oregonian April 19, 1950

“Society: A Number of Society Matrons," The Oregonian September 6, 1915 p. 12.

“Speaker Cites Racial Gains," The Oregonian November 21, 1950 p. 19.

State of Oregon v. Jordan 146 Or. 504 (Or. 1934).

"Strong Protest Entered on Henderson Decision," The Oregonian, January 21, 1948, p. 10.

"Stuart Ball Elected Head at 88 ${ }^{\text {th }}$ Annual Y Meeting," The Oregonian February 18, 1956, p. 6.

Sweetland, Monroe. 1953. "Correspondence to Lafe Compton," Verdell Burdine and Otto G. Rutherford Family Collection 1880s-1980s, Portland State University Special Collections.

Monroe Sweetland, "Correspondence to Oregon Licensed Beverage Association," Verdell Burdine and Otto G. Rutherford Family Collection 1880s-1980s, Portland State University Special Collections.

“Talk Scheduled By Walter White,” The Oregonian July 30, 1950 p. 16.

“That Film Again," The Advocate, January 2, 1932, p. 2.

The City Club of Portland. 1945. "The Negro in Portland: A Survey by the Committee on Race Relations." Portland City Club Bulletin, 26, no. 12. City Club of Portland.

The Urban League of Portland, "Notice! Purpose and Scope," The Observer May 31, 1945 , p. 4.

The Urban League of Portland. 1949. "Ten Tips for Tactful Talkers," Verdell Burdine and Otto G. Rutherford Family Collection 1880s-1980s, Portland State University 
Special Collections and University Archives.

The Urban League of Portland. 1949. "Don't be Misled...About Your Neighbors," Verdell Burdine and Otto G. Rutherford Family Collection 1880s-1980s, Portland State University Special Collections and University Archives.

"This is Right, This is Just, This is Fair," The Oregonian November 6, 1950, p. 6.

Thurber, Horace. "Practical Religion," The Oregonian, October 1, 1945, p. 6.

Tooze, Leslie. "48-Year-Old Lifer Freed After 22 Years in Prison," The Oregonian, May 25,1954, p. 1.

Turner, Wallace. "Chicago Police Report Blasts Hope of Oregon Prisoner for Freedom," The Oregonian, September 16, 1951, p. 22.

Unthank, DeNorval. "Keeping Fit," The Advocate March 21, 1931, p. 4.

"Urban League Asks for FEP: Discrimination Hit By Berry Memo," The Oregonian February 9, 1949, p. 8.

White, Walter. "Appraising Dixie Rebuttal," Trenton Evening Times (Trenton, New Jersey), September 5, 1948, p. 6.

"Who Hurt This Child?" The Oregonian November 2, 1950 p. 10.

"Williams Ave YWCA" PSU Archives December 14, 1951.

“Woman Writes Oregon Jailed Innocent Man," Sacramento Bee, September 12, 1951, p. 22.

"Woman Signs Affidavit Stating Life-Termer Innocent Of Murder," Plaindealer (Kansas City, Kansas), September 21, 1951, p. 1.

"2 Negroes Die, 1 in Jail in Guilds Lake Flare-up," The Oregonian, August 22, 1945, p. 9.

"3 Convicts Shot in Prison Riot: One Man Dead as Result of Salem Disturbance," The Oregonian, August 1, 1936, p. 2.

"11 Cases Filed On Race Law: Official Reports On State Measure," The Oregonian April 17, 1950 p. 9.

"100 Portland Attorneys Ask Commutation for Slayer," The Oregonian, January 14, 1948, p. 10. 


\section{Articles and Anthology Book Chapters}

Deverell, William and Flamming, Douglas. 1999. "Race, Rhetoric, and Regional Identity: Boosting Los Angeles 1880-1930." In Power and Place in the North American West, by Richard White and John M. Findlay, 144-175. Seattle: University of Washington Press.

Dickson, Lynda F. 1997. "Lifting as we Climb: African American Women's Clubs of Denver, 1890-1925." In Writing the Range: Race, Class, and Culture in the Women's West, by Elizabeth Jameson and Susan Armitage, 372-392. Norman: University of Oklahoma Press.

Dippie, Brian W. 1999. "The Winning of the West Reconsidered." In Forging the American Character: Readings in United States History to 1877, by John R. M. Wilson, 190-201. New Jersey: Prentice Hall.

Eastman, Janet. "Change: Humboldt Neighborhood's History, Future: Sleeping in Portland," The Oregonian, January 1, 2015, accessed April 18, 2016, http://www.oregonlive.com/hg/index.ssf/2015/01/north_portlands_humboldt_neig $\underline{\text { h.html. }}$

"Father Lee Owen Stone," Oregon Multicultural Archives Blog, April 17, 2012, accessed April 18, 2016, http://wpmu.library.oregonstate.edu/oregon-multiculturalarchives/2012/04/27/father-lee-owen-stone/.

Gonzales, Deena J. 1996. "A Regendered, Reracialized, and Resituated West." In A New Significance: Re-Envisioning the History of the American West, by Clyde A. Milner II, 283-289. New York: Oxford University Press.

Hardman, Peggy. "Lanier, Ralphael O'hara," Handbook of Texas Online, accessed April 18, 2016, http://www.tshaonline.org/handbook/online/articles/fla88.

"Henry Gunn," accessed June 1, 2014, http://www.wou.edu/provost/library/archives/university/presidents/Gunn.php.

Hogg, Thomas C. 1969. "Negroes and Their Institutions in Oregon." Phylon 272-285.

Johnson, Ethan and Williams, Felicia. 2010. "Desegregation and Multiculturalism in the Portland Public Schools," Oregon Historical Quarterly, 6-37.

Leonard, Kevin Allen. 1999. "Federal Power and Racial Politics in Los Angeles during World War II." In Power and Place in the North American West, by Richard White and John M. Findlay, 87-116. Seattle: University of Washington Press. 
Lipman, Meryl. "Dorothy McCullough Lee (1902-1981)" The Oregon Encyclopedia 2016, accessed April 13, 2016, http://oregonencyclopedia.org/articles/lee_dorothy_mccullough_1902_1981_/\#.V 1BKdZXmrX4.

Mangun, Kimberley. 2008. "Boosting the Bottom Line: Beatrice Morrow Cannady's Tactics to Promote The Advocate, 1923-1933." American Journalism 31-69.

Mangun, Kimberley. 2006. "The (Oregon) Advocate: Boosting the Race and Portland, Too." American Journalism 7-34.

McCormick, Anne O'Hare. “Wendell L. Willkie Rush County," IHB Marker Text Review, accessed March 21, 2016, www.in.gov/history/files/70.1969.1Willkiereview.pdf.

McLagen, Elizabeth. "The Black Laws of Oregon, 1845-1857.” BlackPast.org, 2015. http://www.blackpast.org/perspectives/black-laws-oregon-1844-1857. Accessed May 18, 2016.

"Melvin Arnold," Harvard Library. Accessed June 1, 2014. http://oasis.lib.harvard.edu/oasis/deliver/ div00204.

Mohr, Deb. "Cross Burning at Gamma Phi Beta," Oregon Quarterly, 2014, accessed June 6, 2016, http://oregonquarterly.com/cross-burning-at-gamma-phi-beta.

Moye, J. Todd. 2011. "Focusing Our Eyes on the Prize: How Community Studies Are Reframing and Rewriting the History of the Civil Rights Movement," in Emilye Crosby. 2011. Civil Rights History From the Ground Up: Local Struggles, A National Movement Athens: The University of Georgia Press, 163.

Pascoe, Peggy. 1997. "Race, Gender, and Intercultural Relations: The Case of Interracial Marriage ." In Writing the Range: Race, Class, and Culture in the Women's West, by Elizabeth and Armitage, Susan Jameson, 69-80. Norman: University of Oklahoma Press.

Pearson, Rudy. 2001. ""A Menace to the Neighborhood": Housing and African Americans in Portland, 1941-1945." Oregon Historical Quarterly 158-179.

Pearson, Rudy. “Clow, J.J. (1893-1979)," BlackPast.org, 2015, accessed April 18, 2016, http://www.blackpast.org/aaw/clow-j-j-1893-1979.

Pomeroy, Earl. 1955. "Toward a Reorientation of Western History: Continuity and Environment," The Mississippi Valley Historical Review, 579-600. 
Pomeroy, Earl. 2011. "The Changing West," in John Higham, ed. The Reconstruction of American History. Charleston: Nabu Press.

Ridge, Martin. 1999. "The Life on an Idea: The Significance of Frederick Jackson Turner's Frontier Thesis." In Does the Frontier Experience Make America Exceptional?, by Richard W. Etulain, 73-85. Boston: Bedford/St. Martin's.

Roose, Holly. 'Edwin C. 'Bill' Berry (1910-1987), BlackPast.org: Remembered \& Reclaimed, 2015, accessed March 21, 2016, http://www.blackpast.org/aah/berryedwin-c-bill-1910-1987.

Taylor, Clarence. "African American Religious Leadership and the Civil Rights Movement," The Gilder Lehrman Institute of American History, 2016, accessed June 7, 2016, http://www.gilderlehrman.org/history-by-era/civil-rightsmovement/essays/african-american-religious-leadership-and-civil-rights-m.

Taylor, Quintard. 2012. "Facing the Urban Frontier: African American History in the Reshaping of the Twentieth-Century American West." The Western Historical Quarterly 4-27.

Taylor, Quintard. 1996. "From Esteban to Rodney King: Five Centuries of African American History in the West." Montana: The Magazine of Western History 2-23.

Taylor, Quintard. 1981. "The Great Migration: The Afro-American Communities of Seattle and Portland during the 1940s." Arizona and the West 109-126.

Taylor, Quintard. 1996. "Through the Prism of Race: The Meaning of African-American History in the West." In A New Significance: Re-Envisioning the History of the American West, by Clyde A. Milner II, 289-300. New York: Oxford University Press.

Washington, Margaret. 1993. "African American History and the Frontier Thesis." Journal of the Early Republic 230-241.

Watson, Tara and Rose, Melody. 2010. "She Flies with Her Own Wings: Women in the 1973 Oregon Legislative Session,” Oregon Historical Quarterly, 38-63.

White, Richard. 1986. "Race Relations in the American West." American Quarterly 396416.

\section{Books and Unpublished Manuscripts}

Abbott, Carl. 2008. How Cities Won the West: Four Centuries of Urban Change in Western North America. Albuquerque: University of New Mexico Press. 
Abbott, Carl. 2011. Portland in Three Centuries: The Place and the People. Corvallis: Oregon State University Press.

Almuaguer, Tomas. 1994. Racial Fault Lines: The Historical Orgins of White Supremacy in California. Berkeley: University of California Press.

Anderson, Benedict. 2006. Imagined Communities. London: Verso.

Bernstein, Shana Beth. 2003. Building Bridges at Home in a Time of Global Conflict: Interracial Cooperation and the Fight for Civil Rights in Los Angeles, 1933-1954. Dissertation, Palo Alto: Stanford University.

Buhler, Julie Lorana. 1983. The Civil Rights Movement in Portland, Oregon: 1955-68. Thesis, Eugene: University of Oregon.

Cronon, William. 1992. Nature's Metropolis: Chicago and the Great West. New York: W.W. Norton \& Company.

Crosby, Emilye. 2011. Civil Rights History from the Ground Up: Local Struggles, A National Movement. Athens: University of Georgia Press.

Dorman, Robert L. 2012. Hell of a Vision: Regionalism and the Modern American West. Tucson: The University of Arizona Press.

Gilmore, Glenda Elizabeth. 2008. Defying Dixie: The Radical Roots of Civil Rights 19191950. New York: W.W. Norton \& Company.

Goldfield, David R. 1990. Black, White, and Southern: Race Relations and Southern Culture 1940 to the Present. Baton Rouge: Louisiana State University Press.

Gordly, Avel Lousie with Schechter, Patricia A. 2011. Remembering the Power of Words: The Life of an Oregon Activist, Legislator and Community Leader. Corvallis: Oregon State University Press.

Hayden, Dolores. 1997. The Power of Place: Urban Landscapes as Public History Cambridge: The MIT Press.

Jacobson, Matthew Frye. 1999. Whiteness of a Different Color: European Immigrants and the Alchemy of Race. Cambridge: Harvard University Press.

Janken, Kenneth Robert. 2003. White: The Biography of Walter White, Mr. NAACP. New York: W.W. Norton \& Company.

Lake, Marilyn and Reynolds, Henry. 2008. Drawing the Global Colour Line: White Men's Countries and the International Challenge of Racial Equality. Cambridge: Cambridge University Press. 
Limerick, Patricia Nelson. 1987. The Legacy of Conquest: The Unbroken Past of the American West. New York: W.W. Norton \& Company.

Lucia, Ellis. 1966. The Conscience of a City: Fifty Years of City Club Service in Portland. Portland: The City Club of Portland.

MacColl, E. Kimbark. 1979. The Growth of a City: Power and Politics in Portland, Oregon 1915 to 1950. Portland: The Georgian Press.

Mack, Dwayne A. 2014. Black Spokane: The Civil Rights Struggle in the Inland Northwest. Norman: University of Oklahoma Press.

Mangun, Kimberley. 2010. A Force for Change: Beatrice Morrow Cannady and the Struggle for Civil Rights in Oregon, 1912-1936. Corvallis: Oregon State University Press.

McLagan, Elizabeth. 1980. A Peculiar Paradise: A History of Blacks in Oregon, 17881940. Portland: The Georgian Press.

Millner, Darrell. 1995. On the Road to Equality: The Urban League of Portland Fifty Years. Portland: Urban League of Portland.

Millner, Darrell and Abbott, Carl. 1997. Cornerstones of Community: Buildings of Portland's African American History. Portland: Bosco-Milligan Foundation Architectural Heritage Center.

Milner, Clyde A. 1996. A New Significance: Re-Envisioning the History of the American West. New York: Oxford University Press.

Aldon D. Morris, Aldon D. 1986. The Origins of the Civil Rights Movement: Black Communities Organizing for Change. New York: The Free Press.

Nokes, R. Gregory. 2013. Breaking Chains: Slavery on Trial in the Oregon Territory. Corvallis: Oregon State University Press.

Pearson, Rudy. 1996. African-Americans in Portland, Oregon, 1940-1950. Work and Living Conditions: A Social History. Dissertation, Pullman: Washington State University.

Planning, Portland Bureau of. 1993. The History of Portland's African American Community (1805 to the Present). Albina Community Report, Portland: City of Portland Bureau of Planning.

Pomeroy, Earl. 1957. In Search of the Golden West: The Tourist in Western American New York: Knopf Doubleday Publishing. 
Pomeroy, Earl. 2003. The Pacific Slope: A History of California, Oregon, Washington, Idaho, Utah, and Nevada. Reno: University of Nevada Press.

Schama, Simon. 1995. Landscape and Memory. New York: Vintage Books.

Simons, Charles A. 1998. The African American Press: A History of News Coverage During National Crises, with Special Reference to Four Black Newspapers, 18271965. Jefferson, North Carolina: McFarland \& Company Incorporated Publishers.

Smith, Stacey L. 2013. Freedom's Frontier: California and the Struggle over Unfree Labor, Emancipation, and Reconstruction. Chapel Hill: The University of North Carolina Press.

Swift, David Everett. Black Prophets of Justice: Activist Clergy before the Civil War. Baton Rouge: Louisiana State University Press, 1989.

Taylor, Quintard. 1998. In Search of the Racial Frontier: African Americans in the American West, 1528-1990. New York: W. W. Norton \& Company.

Taylor, Clarence. Black Religious Intellectuals: The Fight for Equality from Jim Crow to the Twenty-First Century. New York: Routledge, 2002.

Watson, Bradley C.S. 1999. Civil Rights and the Paradox of Liberal Democracy. New York: Lexington books.

Webb, Walter Prescott. 1931. The Great Plains. New York: Grosset and Dunlap.

Whitaker, Matthew C. 2005. Race Work: The Rise of Civil Rights in the Urban West. Lincoln: University of Nebraska Press.

White, Richard. 1991. It's Your Misfortune and None of My Own: A New History of the American West. Norman: University of Oklahoma Press.

Wilkerson, Isabel. 2010. The Warmth of Other Suns: The Epic Story of America's Great Migration. New York: Vintage Books.

Worster, Donald. 1985. Rivers of Empire: Water, Aridity, and the Growth of the American West. Oxford: Oxford University Press.

\section{Newspapers}

The Oregonian

The People's Advocate

The Observer 


\section{Archive}

Eugene, Oregon. University of Oregon Libraries. Special Collections and University Archives, National Association for the Advancement of Colored People (NAACP), Portland Branch Records.

Portland, Oregon. Portland State University Millar Library. Special Collections and Archives, Verdell Burdine and Otto G. Rutherford Family Collection, 1880s1980s.

Portland, Oregon. City Club of Portland Archives and Collections. 1945-1957 City Club Bulletin Collection.

Portland, Oregon. Oregon Historical Society Research Library. NAACP of Portland, Oregon records.

Portland, Oregon. The City of Portland Oregon Archives \& Records Management. Police Historical/Archival Investigative Files, Report regarding a Civil Rights Ordinance.

Corvallis, Oregon. Oregon State University Libraries, Special Collections and Archives Research Center. Urban League of Portland Records.

\section{Websites}

The Gilder Lehrman Institute of American History, 2016, accessed June 7, 2016, http://www.gilderlehrman.org.

“Harry W. Bruck," FindAGrave.com September 29, 2012, accessed April 18, 2016, http://www.findagrave.com/cgi-bin/fg.cgi?page=gr\&GRid=97980315.

“Julia Smith 1915-2010,” Inside Bay Area Obituaries April 11, 2010, accessed April 18, 2016, http://www.legacy.com/obituaries/insidebayarea/obituary.aspx?n=juliasmith\&pid=141676805.

The Oregon Encyclopedia 2016, accessed April 13, 2016, http://oregonencyclopedia.org.

"Mission and History," National Urban League, accessed May 27, 2015. http://nul.iamempowered.com/who-we-are/mission-and-history.

"The Online Reference Guide to African American History." BlackPast.org Remembered and Reclaimed, 2015, accessed June 1, 2016, http://www.blackpast.org/.

"Urban League of Portland: The Archival Collection." Oregon Multicultural Archives, 2009, accessed June 1, 2016, http://scarc.library.oregonstate.edu/oma/ulpdx/. 


\section{Documentaries}

Jelsing, Nadine. "Portland Civil Rights: Lift Ev'ry Voice." Oregon Public Broadcasting August 18, 2015.

http://www.opb.org/television/programs/oregonexperience/segment/portlandcivil-rights-lift-evry-voice/ Accessed May 23, 2016.

Tuttle, Jon. "Local Color: Oregon's Forgotten History Civil Rights." Oregon Public Broadcasting May 01, 1999, http://watch.opb.org/video/1593884540/accessed May 23, 2016, 1:48. 